\title{
WestVirginiaUniversity
}

THE RESEARCH REPOSITORY @ WVU

Graduate Theses, Dissertations, and Problem Reports

2004

\section{Mechanism of action of NSC3852, a breast cancer differentiation agent}

Anna Martirosyan

West Virginia University

Follow this and additional works at: https://researchrepository.wvu.edu/etd

\section{Recommended Citation}

Martirosyan, Anna, "Mechanism of action of NSC3852, a breast cancer differentiation agent" (2004). Graduate Theses, Dissertations, and Problem Reports. 2119.

https://researchrepository.wvu.edu/etd/2119

This Dissertation is protected by copyright and/or related rights. It has been brought to you by the The Research Repository @ WVU with permission from the rights-holder(s). You are free to use this Dissertation in any way that is permitted by the copyright and related rights legislation that applies to your use. For other uses you must obtain permission from the rights-holder(s) directly, unless additional rights are indicated by a Creative Commons license in the record and/ or on the work itself. This Dissertation has been accepted for inclusion in WVU Graduate Theses, Dissertations, and Problem Reports collection by an authorized administrator of The Research Repository @ WVU.

For more information, please contact researchrepository@mail.wvu.edu. 
Mechanism of action of NSC3852, a breast cancer differentiation agent.

Anna Martirosyan

Dissertation submitted to the

School of Medicine

at West Virginia University

in partial fulfillment of the requirements

for the degree of

Doctor of Philosophy

in Pharmacology and Toxicology

Jeannine S. Strobl, Ph.D., Chair

Daniel Flynn, Ph.D.

Peter Gannett, Ph.D.

Knox Van Dyke, Ph.D.

William Wonderlin, Ph.D.

Department of Pharmacology and Toxicology

Morgantown, West Virginia

2004

Key words: Quinolines, Differentiation, Apoptosis, Oxidative Stress 


\begin{abstract}
Mechanism of action of NSC3852, a breast cancer differentiation agent.
\end{abstract}

\begin{abstract}
Anna Martirosyan
The development of tumor cell differentiation agents is new initiative in cancer treatment research. The goal of this project was to identify breast cancer differentiation agents by screening quinoline ring-containing compounds obtained form National Cancer Institute Compound Library. Of six differentiation-inducing quinolines NSC3852 was chosen as a "lead" compound. Our results demonstrate that NSC3852 is an inhibitor of HDAC activity in HeLa and MCF-7 cells nuclear extracts. NSC3852 caused superoxide generation in MCF-7 cells in a NADPH oxidase-dependent fashion, and NSC3852induced oxidative stress led to the shift in a redox potential of the cells to a more oxidized state. This change in redox status of the cells was accompanied by the accumulation of hypophosphorylated $\mathrm{pRb}$, downregulation of E2F-1 and Myc transcription factor protein levels, and cell differentiation. Superoxide formation in response to NSC3852 exposure caused DNA damage and subsequently apoptosis. MCF-7 cells growth was inhibited. NAcetyl- ${ }_{\mathrm{L}}$-cysteine (glutathione precursor) pretreated MCF-7 cells were protected against DNA damage, apoptosis, and Rb/E2F/Myc modulation induced by NSC3852. Inhibition of cell growth and induction of cell differentiation in MCF-7 by NSC3852 was partially blocked by NAC. This data suggest that mechanisms in addition to oxidative stress are involved in cell differentiation and growth inhibition by NSC3852 in MCF-7 cells.
\end{abstract}




\section{DEDICATION}

To my parents, Drs. Martirosov R. and Hambardzumyan T. 


\section{ACKNOWLEDGMENTS}

I would like to acknowledge many people, whose support helped me to complete this dissertation. First, I would like to thank my research adviser and friend Dr. Jeannine Strobl, for being a great mentor through all those years; for her guidance, encouragement, endless patience and help in all aspects of science and life. I would also like to express my gratitude to my graduate committee: Drs. Daniel Flynn, Peter Gannett, Knox Van Dyke and William Wonderlin for their advice and guidance. I would like to thank my friends and colleagues: Rayhana Rahim-Bata, Zaroui Melkoumian, Charles Clarke, Meredith McCracken and Qun Zhou. I am also thankful to my friend, colleague and roommate Elena Kazhemyakina for her support and encouragement through all those years.

I thank my family, whose love and support I feel every day of my life. Finally, I would like to thank Hakob Zarobyan for his help, patience and endless optimism. 


\section{TABLE OF CONTENTS}

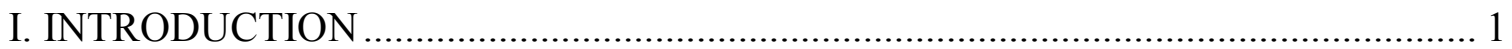

1. Breast cancer and current methods of therapy .................................................... 1

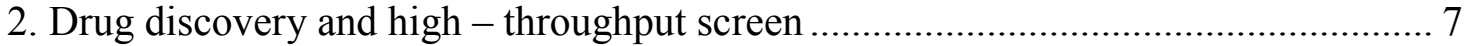

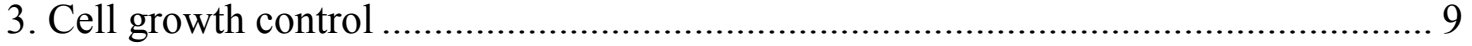

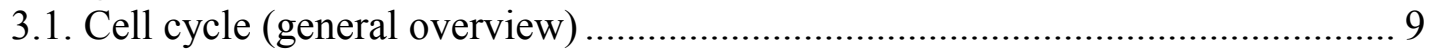

3.2. Cell cycle dysregulation and differentiation therapy .................................... 15

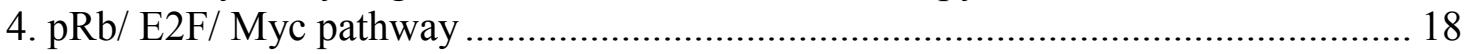

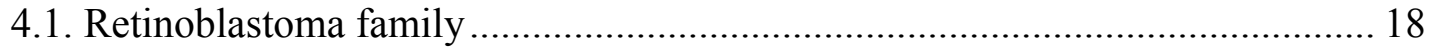

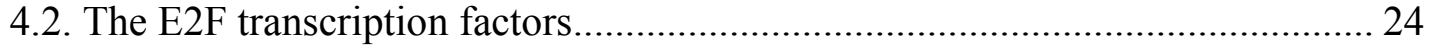

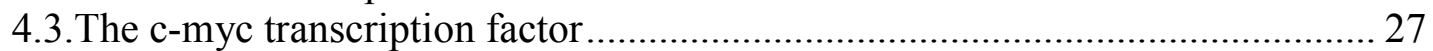

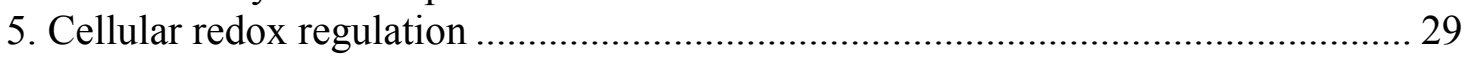

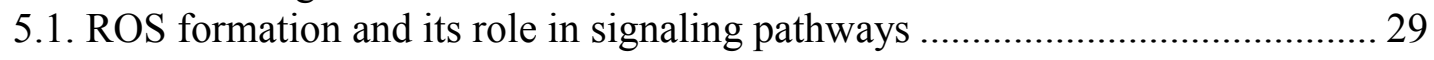

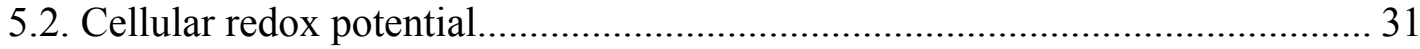

5.3. Modulation of the cell cycle and differentiation by cellular redox ................... 32

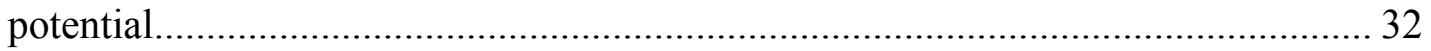

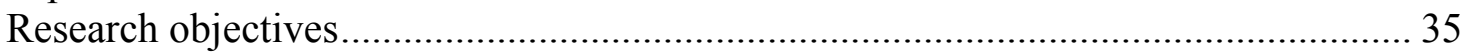

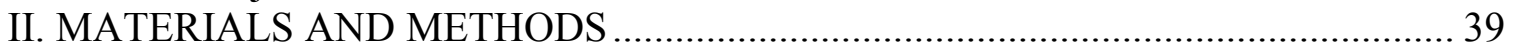

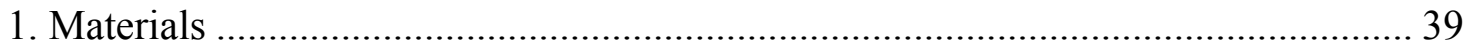

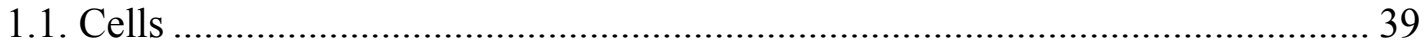

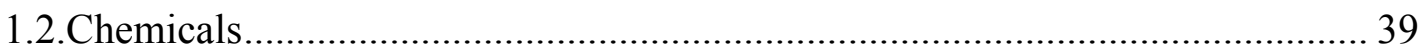

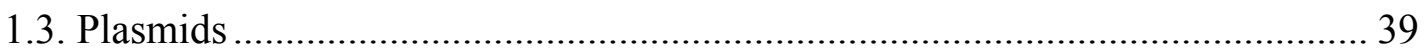

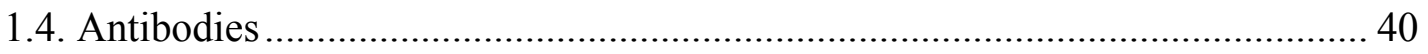

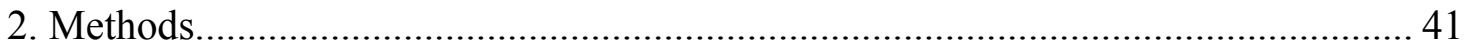

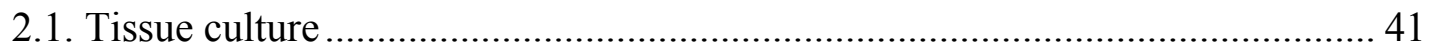

2.2. MTS (3-(4,5-dimethylthiazol-2-yl)-5-(3-carboxymethoxyphenyl)-2-(4-......... 41

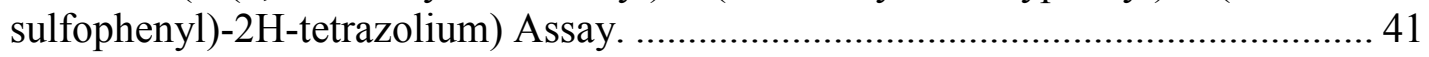

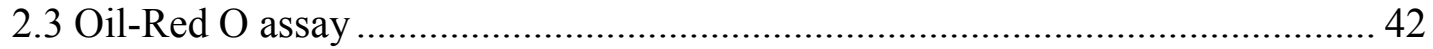

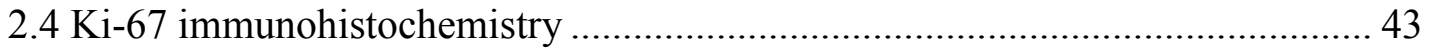

2.5. Cell Death ELISA (enzyme-linked immunosorbent assay) .............................. 44

2.6. Histone Deacetylase (HDAC) Fluorescent Activity Assay .............................. 45

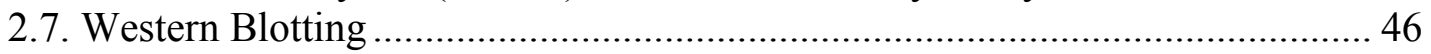

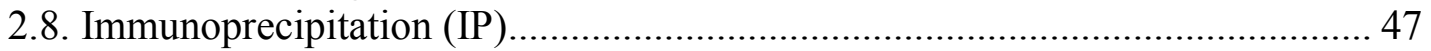

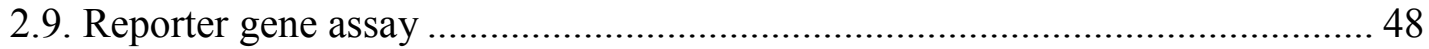

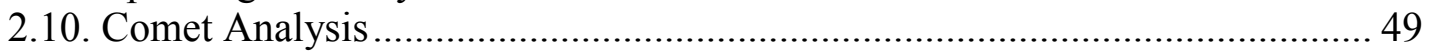

2.11. Dihydroethidium Fluorescence .............................................................. 51

2.12. Colorometric determination of reduced and oxidized glutathione ................. 51

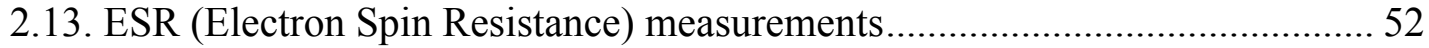

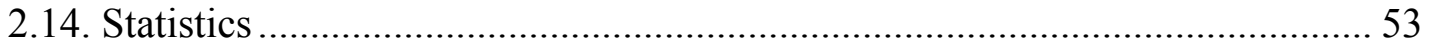

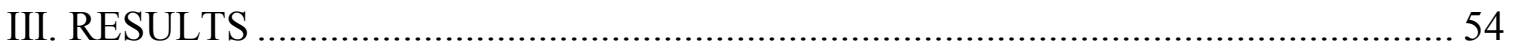

Chapter 1. Screening of Quinoline ring - containing compounds ............................. 54

1.1. Survival of breast tumor cells treated with quinoline ring - containing compounds 
1.2. Accumulation of cytoplasmic lipid droplets in MCF-7 cells caused by NSC



1.3. Effect of NSC compounds on Ki67 antigen in MCF-7 cells ................................ 62

MCF-7

1.4. Inhibition of HDAC enzymatic activity 64

1.5. NSC compounds cause growth suppression in MCF-7 breast cancer cells ....... 67 1.6. Quinoline ring - containing compounds induce apoptosis in MCF-7 and MCF-



1.7. DNA damage induced by quinoline ring compounds....................................... 74

1.8. NSC compounds cause growth suppression in MCF-10A normal mammary ... 78

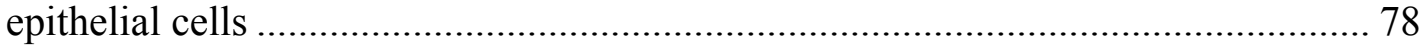

1.9. Significant findings and future directions...................................................... 80

Chapter 2. NSC3852 modulate Rb/E2F-1/Myc pathway .......................................... 83

2.1. NSC3852 induces accumulation of hypophosphorylated pRb in MCF-7 cell.. 85

2.2. NSC3852 causes suppression of E2F-1 protein in MCF-7 cells ....................... 89

2.3. Immunoblot analysis of E2F protein family members .................................... 92

2.4. Accumulation of hypophosphorylated form of pRb induced by NSC3852 leads

to an increase in pRb/E2F-1 complex formation ..................................................... 94

2.5. Suppression of Myc protein by NSC3852 in MCF-7 cells ............................... 96

2.6. NSC3852 influence on E2F-1 and Myc transcriptional activity........................ 99

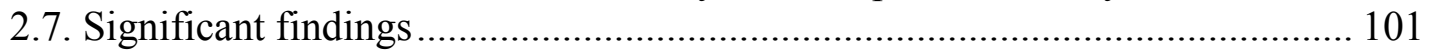

Chapter 3. NSC 3852 affect redox status of MCF-7 human breast cancer cell .......... 102

3.1. Modulation of pRb/E2F-1/Myc pathway by NSC3852 can be blocked by ..... 104

pretreatment of MCF-7 cells with NAC .............................................................. 104

3.2. Effect of NAC on Ki-67 index in NSC3852 treated cell ................................ 108

3.3. NAC protects MCF-7 cells from DNA damaging effect of NSC3852 ............ 110

3.4. NSC3852 induced apoptosis is blocked by NAC ………................................ 113

3.5. NAC partially blocks growth inhibition of MCF-7 cells induced by NSC3852

3.6. NSC3852 mediates ROS generation in MCF-7 cells.................................... 117

3.7. Superoxide visualization by Dihydroethidium ............................................. 120

3.8. GSH/GSSG ratio in MCF-7 cells is altered by NSC3852 ……...................... 122

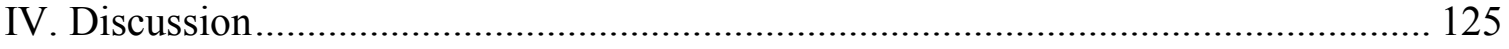

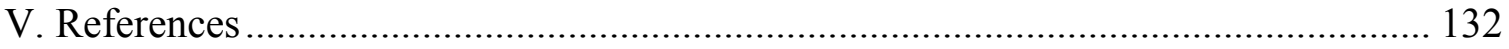




\section{LIST OF FIGURES}

Figure 1. The Cell Cycle ........................................................................................ 10

Figure 2. Schematic representation of $\mathrm{pRb}$ phosphorylation and E2F release during G0-S

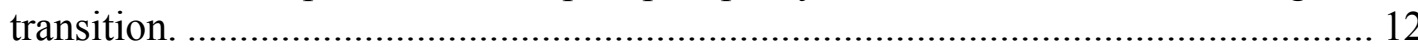

Figure 3. Putative regulatory features of retinoblastoma proteins. Red dots represent

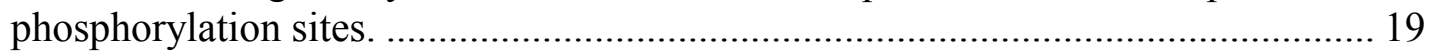

Figure 4: General scheme of E2F actions on transcriptional activity.............................. 21

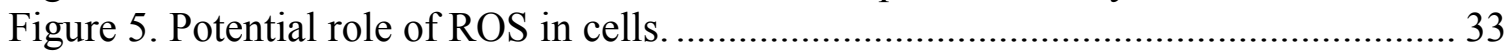

Figure 6. Chemical structures of quinoline ring - containing compounds...................... 56

Figure 7. Visualization of cellular differentiation in MCF-7 cells using Oil Red O

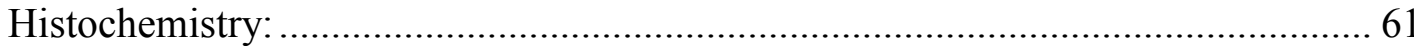

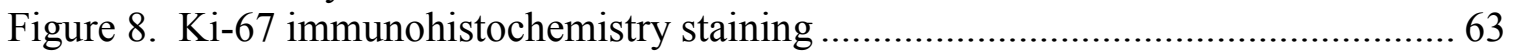

Figure 9. Growth suppression induced by NSC compounds ......................................... 68

Figure 10. Induction of apoptosis by NSC compounds ................................................ 72

Figure 11. DNA damage induced by quinolines....................................................... 75

Figure 12. MCF-10A cell growth .......................................................................... 79

Figure 13. Temporal relationship between cell plating time, treatment time and the MCF-

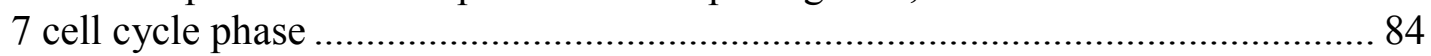

Figure 14. NSC3852 induced changes in pRb phosphorylation state.............................. 87

Figure 15. Downregulation of E2F-1 protein level by NSC3852 ……………............... 90

Figure 16. Effect of NSC compounds on E2F family members ....................................... 93

Figure 17. NSC compound increased pRb/E2F-1 complex formation............................. 95

Figure 18. Downregulation of Myc protein level by NSC3852 ……............................... 97

Figure 19. NSC compounds affect E2F-1 and Myc transcriptional activity................... 100

Figure 20. Model: NSC3852 mechanism of action. ................................................... 103

Figure 21. NAC reverses the effect of NSC3852 on Rb/E2F-1/Myc pathway............... 105

Figure 22. Effect of NAC on Ki-67 index in NSC3852 treated cells ............................. 109

Figure 23. NAC protects MCF-7 from DNA damage caused by NSC3852 ................... 111

Figure 24. NAC blocks NSC3852 induced apoptosis................................................ 114

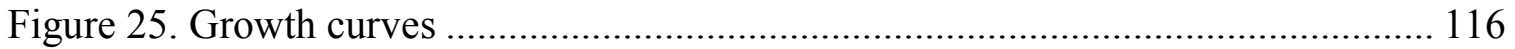

Figure 26. Generation of free radicals in NSC3852 treated MCF-7 cells ..................... 119

Figure 27. Visualization of superoxide inside the cells.............................................. 121

Figure 28. GSH/GSSG ratio in MCF-7 cells treated with NSC3852 .......................... 123

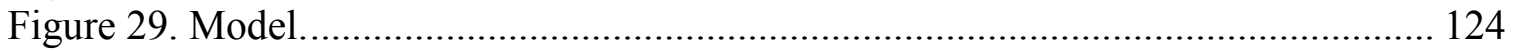




\section{LIST OF TABLES}

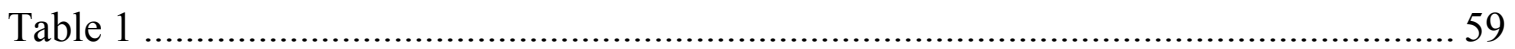

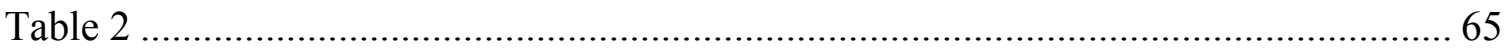




\section{LIST OF ABBREVIATIONS}

$\begin{array}{ll}\text { ATP } & \text { Adenosine Triphosphate } \\ \text { BSA } & \text { Bovine Serum Albumin } \\ \text { CDK } & \text { Cyclin dependent kinase } \\ \text { DPI } & \text { Diphenylene iodonium } \\ \text { DMEM } & \text { Dulbecco's modified Eagle's medium } \\ \text { DMSO } & \text { Dimethyl sulfoxide } \\ \text { DMPO } & \text { 5.5-dimethyl-1-pyrroline-N-oxide } \\ \text { DTNB } & 5 \text { 5-dithiobis-2-nitrobenzoic acid } \\ \text { DTT } & \text { Dithiothreitol } \\ \text { DPPH } & \text { 1,1-diphenyl-2-picrylhydrazyl } \\ \text { EDTA } & \text { Ethyelenediamine Tetraacetic acid } \\ \text { FITC } & \text { Fluorescence isothiocyanate } \\ \text { ER } & \text { Estrogen Receptor } \\ \text { ESR } & \text { Electron Spin Resistance } \\ \text { FBS } & \text { Fetal Bovine Serum } \\ \text { GS } & \text { Glutathione Synthase } \\ \text { GSG } & \text { Glutathione } \\ \text { GSSG } & \text { Glutathione Disulfide } \\ \text { GR } & \text { Glutathione Reductase } \\ \text { HBSS } & \text { Hank's Balanced Salt Solution } \\ \text { HDAC } & \text { Histone deacetylase } \\ \text { MAPK } & \text { Mitogens-activated protein kinase } \\ \text { MEGM } & \text { Mammary Epithelial Cell Growth Medium } \\ \text { MTS } & \text { (3-(4,5-dimethylthiazol-2-yl)-5-(3carboxymethoxyphenyl) } \\ & \text { 2-(4- sulfophenyl)-2H-tetrazolium) } \\ \text { NAC } & \text { N-Acetyl-1-cysteine } \\ \text { NADPH } & \text { Nicotinamide adenine dinucleotide } \\ \text { NSC } & \text { National Service Center } \\ \text { PBS } & \text { Phosphate buffer saline } \\ \text { PMSF } & \text { Phenylmethylsulfonyl fluoride } \\ \text { PVDF } & \text { Polyvinylidene Difluoride } \\ \text { Rb } & \text { Retinoblastoma } \\ \text { ROS } & \text { Reactive oxygen species } \\ \text { SAHA } & \text { Superoylanilide Hydroxamic Acid } \\ \text { SOD } & \text { Superoxide dismutase } \\ \text { TBS } & \text { Tris buffered saline } \\ & \end{array}$




\section{INTRODUCTION}

\section{Breast cancer and current methods of therapy}

Cancer of the breast is the most common form of cancer that affects women. About one in eight women in the United States will develop breast cancer during her lifetime. Excluding cancer of the skin, breast cancer is the next common cancer among women. It accounts for nearly one of every three cancers diagnosed in US women. Men are generally at low risk of developing breast cancer. In 2003, 39,800 women were expected to die from this disease (American Cancer Society, Surveillance Research, 2003). Only lung cancer accounts for more cancer deaths in women (Jemal A. et al., 2003). Time since diagnosis, age at diagnosis, stage at diagnosis, race/ethnicity and socioeconomic factors are the factors that influence breast cancer survival. Factors that increase the relative risk for breast cancer in women are: age, certain inherited genetic mutations for breast cancer, two or more first degree relatives with breast cancer diagnosed at an early age, high - dose radiation to chest, atypical hyperplasia, late age at full - term pregnancy, early menarche, late menopause, oral contraceptive use, long-term use of hormone - replacement therapy, and obesity (Hulka B., S. et al., 2001).

Current methods of breast cancer treatment include surgery, radiation therapy, systemic therapy (biologic therapy, chemotherapy, hormone therapy, and preventive chemotherapy. Treatment decisions are made after consideration of the optimal treatment available for the breast cancer patient. A number of parameters, such as tumor size, involvement of the axillary lymph nodes, presence of metastasis and presence of steroid receptors are considered. 
There are different surgical options available. Breast-conserving surgery includes lumpectomy and partial mastectomy. It is followed by radiation therapy. Other types of surgery include total mastectomy, modified radical mastectomy and radical mastectomy. Those types of surgery are also followed by adjuvant therapy. Unfortunately, surgery or radiation therapy involving the axilary nodes can lead to serious swelling of the arm caused by fluid retention, known as lymphedema. (Fisher B. et al., 2002).

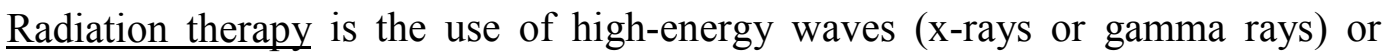
streams of particles (electrons, protons, neutrons, alpha particles, and beta particles). The understanding of how radiation works in the body made this, one of the oldest cancer therapies, a significant part of cancer treatment. Radiation therapy is received by $50-60 \%$ of cancer patients at some time during their cancer treatment. Radiation therapy typically is used as an adjuvant treatment but can be used before surgery to shrink a large tumor so that it can be surgically removed. It is also used as a palliative treatment. Radiation treatment is given in small doses or fractions over several weeks. Cells that are actively dividing are more radiosensitive, but the disadvantage of the radiation therapy is that it does not distinguish between cancer cells and cells of normal tissues. And, the damage to normal cells can result in serious side effects, such as hair loss, lung inflammation, soft tissue changes, rib fractures, and development of second cancer.

There are two types of radiation therapy. External radiation therapy uses a source of the radiation outside the body. With internal radiation, the radiation is directed to the breast region from within the tissue. Radioactive substances sealed in needles, seeds, wires, or catheters are placed directly into or near the cancer. The advantage of this type 
of radiation therapy is the ability to deliver a high dose of radiation to a small area (Early breast cancer trialists' collaborative group, 2000).

Chemotherapy is a cancer treatment that uses drugs to stop the growth of cancer cells, either by killing the cells or stopping cells from proliferation. The way the chemotherapy is given depends on the type and stage of the cancer being treated. If systemic chemotherapy is used then the drug is taken orally or intravenously, it enters the blood stream and can reach cancer cells throughout the body. When chemotherapy is placed directly in the spinal cord, a body cavity such as the abdomen, or an organ, the drugs mainly affect cancer cells in those areas. Chemotherapy is used as adjuvant therapy when there is a high risk of disease recurrence or as a neoadjuvant therapy to shrink a tumor before surgery or radiation therapy.

Chemotherapy may also be used to treat patients with advanced stages of breast cancer to help control the disease, prolong survival, relieve symptoms, and improve quality of life. Chemotherapeutic drugs can cause both short- and long term side effects or complications. Chemotherapy destroys fast growing cells and does not distinguish between cancer cells and normal, healthy ones. Because cells of skin, nails, hair and blood divide quickly most common side effects are hair thinning or loss of hair over the entire body, dry skin, and weak nails. Cells of the digestive tract are affected also; this explains side effects such as diarrhea, mouth sores, nausea, and vomiting. Blood cells are affected by chemotherapy. Treatment is suspended if any type of blood cells reaches the lowest allowed level. As soon as the blood cell production recovers, during a rest period, treatment can be continued. Some drugs, such as doxorubicin (Adrinomycin) or epirubicin (Ellence) can cause permanent damage to the heart. More rarely, as a result of 
the chemotherapy itself another cancer develops, such as leukemia. Research has established that combinations of chemotherapy drugs are more effective than one drug alone for breast cancer. One of the hurdles in the adjuvant therapy is that the tumor cells are either inherently resistant or develop resistance to chemotherapy. The use of combination therapy reduces the chances of the cancer becoming resistant to one drug. The most common chemotherapy combinations for breast cancer treatment are listed below: CMF for cyclophosphamide, methotrexate, and 5-fluorouracil; CMFP for cyclophosphamide, methotrexate, 5-fluorouracil and prednisone; CMFVP for cyclophosphamide, methotrexate, 5-fluorouracil, vincristine and prednisone; CAF for cyclophosphamide, doxorubicin, and 5-fluorouracil; CEF for cyclophosphamide, epirubicin and 5-fluorouracil, AT for doxorubicin and paclitaxel (Hortobagyi G., N., 1998).

Estrogen is one of the major promoters of cell growth in hormone dependent breast cancer. The goal of hormone therapy is to deprive the cancer tissue of estrogen, resulting in inhibition of cancer cell growth. All breast cancers are now routinely tested for the estrogen/progesterone receptor status. Hormone therapy has proven effective only in hormone receptor - positive or unknown status breast cancers. Hormone therapy is not used with estrogen/progesterone receptor negative breast cancer. Hormone therapy acts by either blocking estrogen from reaching responsive receptors on cancer cells or inhibiting the synthesis of estrogen. Hormone treatment include: estrogen receptor modulators (tamoxifen, raloxifene), used for both pre and postmenopausal women, considered first-line therapy; aromatase inhibitors (anastrozole, letrozole, exemestane), which block estrogen synthesis by tissues other than the ovaries and are prescribed only 
to postmenopausal women as first-line therapy instead of tamoxifen, or as second-line therapy after tamoxifen resistance is developed (Seralini G. et al., 2001); progestins (megestrol acetate), reduce the effect of estrogen of breast cancer cells and are used as the third - line therapy, if needed; luteinizing hormone- releasing hormone-like drugs (goserelin, leuprolide acetate), which reduce estrogen produced by the ovaries, are used only in premenopausal women, and may be used before, after, in place of, of with tamoxifen. Tamoxifen is the oldest and the most commonly used antiestrogen drug. Among the most serious side effects of tamoxifen is increased risk of endometrial cancer. There have been some reports of liver toxicity, eye problems, slightly increased risk of stroke or developing cataracts (Early Breast Cancer Trialists' Collaborative Group, 1998).

Biological therapy also is known as biological response modifier therapy. A good example of biological therapy is trastuzumab (Herceptin). It is a monoclonal antibody that binds to the HER-2/neu receptors on the surface of some breast cancers. HER-2/neu is a normally occurring gene. However, in cancer cells this gene is often mutated and becomes abnormal. When the HER-2/neu protein binds to the receptor on the surface of tumor cell, it generates a signal that causes the cell to divide. Overexpression of HER2/neu has been shown to play an important role in the malignant transformation and aggressiveness of breast cancer. Herceptin binds to the HER-2/neu receptor, making it impossible for HER-2/neu protein to bind, thus inhibiting tumor from growth. It can be used alone or in combination with chemotherapy drugs, such as Taxoter (taxol), Adriamycin (doxorubicin), and cyclophosphamide. Herceptin is well tolerated, but it can 
cause nausea and headache. A serious side effect of Herceptin is heart toxicity (Cobleigh M., A., 1999).

Surgery, radiation, chemotherapy and hormone therapy can now cure some cases of cancer. But future methods should be more effective. Therapies that are now available for internal tumors often give rise to harmful side effects that can compromise the benefits of treatment. Existing therapies for such internal cancers can also fail in many cases. Although some advances in the treatment of cancer have been made, the modern understanding of the genetic basis of cancer is providing the means to find more specific and less toxic treatments for cancer. The ideal anticancer treatment should be limited to cancer cells and should cause very few, if any, side effects. 


\section{Drug discovery and high - throughput screen}

Recent advances in technology, expanded knowledge of the molecular bases of tumorogenesis and metastasis, and the development of diversity of compounds that can be tested for activity against known targets lead to the development of increasingly rapid, selective and reliable high - throughput screening assays, which are applied in the early phases of drug discovery. These assays allow screening of a very large number of compounds in an automated fashion. Most high - throughput screening assays can be grouped into cell - free (biochemical) or cell based (ex - vivo) assays. Cell based assays are becoming more widely used format in high - throughput screening, because compounds initially identified in a biochemical assay sometimes fail later in the discovery process as drug candidates. In some cases they are not able to penetrate the cell; in other cases they do not interact with the target effectively in the cell. Commonly used cell based assays include enzyme - reporter assay and cell activity assays with fluorescent, luminescent or colorimetric readouts. Automated assays allow rapid screening of large compound libraries to identify compounds that show the desired effect, or so cold "hits" (Hertzberg R., P. et al., 2000). A good example of high - throughput screening of large compound library is the In Vitro Cell Line Screening Project. This project required approximately five years (1985 - 1990) to develop. The project is designed to screen up to 20,000 compounds per year for potential anticancer activity, and the operation of this screen utilizes 60 different human tumor cell lines (representing leukemia, melanoma and cancers of the lung, colon, brain, ovary, breast, prostate, and kidney). The aim of the project is the development of the library of compounds, showing selective growth inhibition or cell killing properties in particular tumor cell lines, 
available for further evaluation (NCI, DTP human tumor cell line screen, http://dtp.nci.nih.gov/branches/btb/ivclsp.html). Hits are then further screened to select more specific and potent compounds called "leads". The next step in the drug discovery process is further testing of the leads to determine targets upon which they act (if not known) in cells with subsequent in vivo assays (animal models) in order to select compounds that may become drug candidates for clinic (Johnston P., A. et al., 2002).

In this study we preformed high-throughput screening of quinoline ringcontaining compounds obtained from National Cancer Institute Compound Library to identify "lead" compound, and further investigate its mechanisms of action. 


\section{Cell growth control}

\subsection{Cell cycle (general overview)}

Cell division is a process that is required throughout the life of all eukaryotic cells. The replicative cycle of the cells, which ensures that there is complete and accurate replication of the cell before the division is known as the cell cycle (Figure1). It is a highly organized and complex process that requires a carefully timed sequence of events including cycle alterations in gene expression and protein phosphorylation. The length of the cell cycle can vary considerably. There are two principal stages of the cell cycle: interphase and mitosis. The period between cell divisions when the cell possesses an intact nuclear membrane, with chromatin dispersed throughout the nucleus is called interphase. Stage of the division itself is called mitosis. Interphase is subdivided into $G_{1}$, $\mathrm{S}$ and $\mathrm{G}_{2}$ phases. Cell division (cytokinesis) occurs during mitosis (M) phase. $\mathrm{G}_{1}$ (G for gap) phase follows mitosis. During this phase the cellular genome is in the diploid state. This is followed by $\mathrm{S}$ phase (synthesis), during which DNA is replicate, and finally by $\mathrm{G}_{2}$ during which essential proteins for $\mathrm{M}$ phase are synthesized. A fifth phase has also been identified and is known as $\mathrm{G}_{0}$. It occurs when a viable cell is not involved in the active cell cycle. Cells enter such quiescent phase under the certain conditions such as starvation or differentiation. Some non-dividing cells, for example neurons or skeletal muscle fibers, are said to be in $\mathrm{G}_{0}$ phase and are not able to re - enter the cell cycle. Other cells, such as hepatocytes, fibroblasts and lymphocytes can be stimulated into the cell cycle by external factors (mitogens). $\mathrm{G}_{0}$ cells perform tissue - specific functions, but unlike terminally differentiated cells, $\mathrm{G}_{0}$ cells retain the ability to enter the proliferating cell 

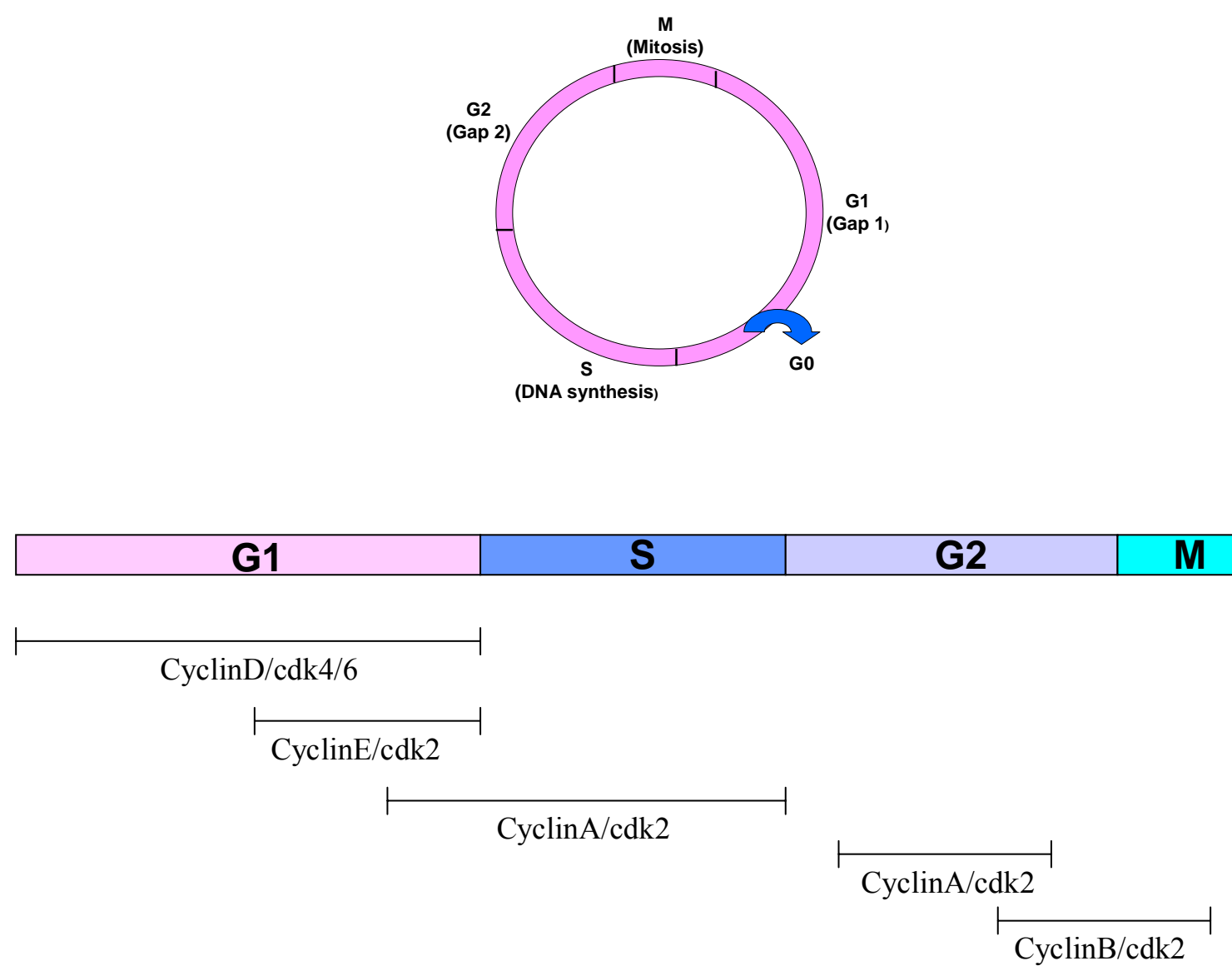

Figure 1. The Cell Cycle. Cyclins and cyclin-dependent kinases during the cell cycle. 
cycle, responding to extracellular factors. The decision for the $\mathrm{G}_{0}$ cell to enter the cell cycle or for the cycling cell to exit into $\mathrm{G}_{0}$ is made shortly before $S$ in late $\mathrm{G}_{1}$ period.

The phases of cell cycle have no definite start and finish point, but each one is a stage at which one function is coming to an end and another is beginning. The cell cycle is controlled by three families of cell cycle regulators: cyclins, cyclin dependent kinases (CDKs), and cyclin - dependent kinase inhibitors. The concentration of cyclins varies during the course of cell cycle. Once the concentration of cyclin has reached a critical level (as a response to mitogenic stimuli) it binds to corresponding CDK and activates it. Some CDKs are activated by more than one cyclin. Currently, 14 cyclins and 8 CDKs have been identified, although the function of all of them has not been resolved (Gillett C., E. et al., 1998). There are two important decisions made during cell cycle: cell decision to enter from $G_{1}$ into $S$ phase, which is made late in $G_{1}\left(G_{1}\right.$ checkpoint), and cell decision to enter mitosis $\left(G_{2}\right.$ checkpoint). Cyclins and CDKs play key role in control of cell cycle checkpoints. $G_{1}$ checkpoint is controlled by retinoblastoma nuclear phosphoprotein $(\mathrm{pRb}) . \mathrm{pRb}$ is controlled by changes in its phosphorylation state (Figure 2). During $\mathrm{G}_{0}$ and early $\mathrm{G}_{1}$ phases $\mathrm{pRb}$ acts as an inhibitor of cell cycle and is present in its hypophosphorylated form. In that form $\mathrm{pRb}$ is bound to $\mathrm{E} 2 \mathrm{~F}$ transcription factor and keeps it transcriptioanlly inactive. At $\mathrm{G}_{1}$ checkpoint however, $\mathrm{pRb}$ becomes phosphorylated by complexes of cyclin D with CDK4/6, and of cyclin E with Cdk2. Upon phosphorylation a transcriptionally active E2F is released, it induces several cell cycle - dependent genes including those for thymidine kinase, dihydrofolate reductase, DNA polymerase $\alpha$, the protooncogenes c-myc and N-myc, cdc2, the genes for cycline E and $A$, and E2F gene itself. These events ensure $\mathrm{G}_{1}$ to $\mathrm{S}$ progression. Detailed 
$G_{0} /$ early $G_{1}$ $\longmapsto$

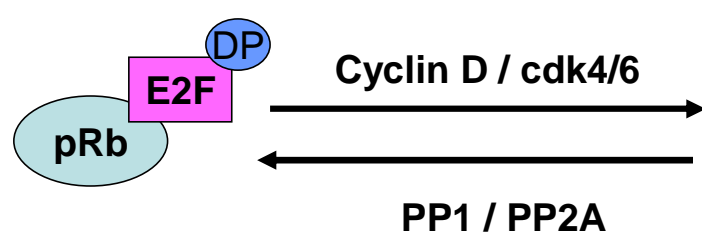

Late $G_{1}$ / early $S$

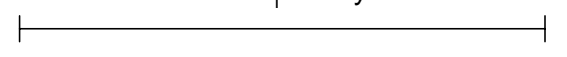

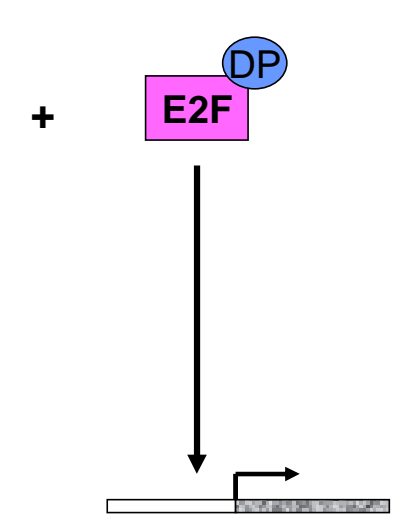

Transcription of S phase genes

Figure 2. Schematic representation of $\mathrm{pRb}$ phosphorylation and E2F release during G0-S transition. 
description of $G_{1}$ to $S$ progression is given later in introduction. $G_{2}$ checkpoint is controlled by $\mathrm{M}$ phase promoting factor (MPF), which consists of CDK1 and its activating mitotic cyclins, cyclins A and B. Cyclin A-CDK1 controls the completion of S phase and the preparation for mitosis. The B cyclins take over from cyclin A as active partner of CDK1 during mitosis, and cyclin B-CDK1 controls mainly the completion of mitosis. Mitotic division starts only when CDK1 has been phosphorylated at threonine 14 and tyrosine 15 by WEE1 (Cdc2-specific tyrosine kinase), at threonine 161 by CAK, and dephosphorylated at threonine 14 and tyrosine 15 by CDC25 (Lohka, M. J., et al., 1988). The activation of CDK1 leads to the phosphorylation of structural proteins in nucleus, such as nucleolin, nuclear lamins, and vimentin, and cell proceeds to the subsequent stages of mitotic and cellular division. As it was mentioned above, activation of CDK by cyclin plays an important role in cell cycle progression. But CDKs are also regulated by CKIs. These inhibitors can be upregulated and, thus block activation of CDK by cyclin when required. There are two families of CKIs: Ink4 and Cip/Kip. The Cip/Kip family consists of p21, p27 and p57. These inhibitors have wide ranging roles and inhibit a number of different CDKs. The Ink4 family consists of p15, p16, p18 and p19. Members of this family inhibit the action of CDK4, and p19 also was shown to inactivate MDM2 (p53 regulatory protein), allowing increase in p53 stability and subsequent cell cycle arrest (Pomerantz J., et al., 1998).

There are two distinct forms of eukaryotic cell death: necrosis and apoptosis. Necrotic cell death is caused by gross cell injury, and results in the death of groups of cells within the tissue. In contrast, when a cell reaches $\mathrm{G}_{1}$ checkpoint, it can be directed to go into S phase or, if the cell is likely to be damaged, it can be sent into programmed 
cell death, known as apoptosis. It can result in the death of an individual cell. Apoptosis is the most common form of eukaryotic cell death. Inappropriate regulation of apoptosis plays an important role in pathological conditions such as cancer (Gerard I. Evan and Karen H. Vousden, 2001). Apoptosis is regulated in the cell by cysteine proteases known as caspases, and it is a process characterized by specific morphologic and biochemical changes. There are two main pathways to apoptotic cell death. One involves so called death receptors, such as TNF or the FAS. The second pathway depends on participation of mitochondria, and is regulated by proapoptotic and antiapoptotic members of Bcl-2 family. Both pathways have the same end result: activation of caspase and subsequent cleavage of specific cellular substrates (Katja C. Zimmermann and Douglas R. Green, 2001). During apoptosis the endogenous endonuclease cleaves double stranded DNA at the most accessible internucleosomal linker regions, generating mono- and oligonucleosomes. Due to the fact that DNA degradation occurs several hours before plasma membrane breakdown, there is the specific stage of apoptosis that is characterized by the enrichment of mono- and -oligonucleasomes in the cytoplasm of the apoptotic cells (Terui, Y. et al, 1995).

There has been considerable progress in identifying the molecules that drive the cell cycle, and accumulating evidence indicates that derangements in the cell cycle machinery contributes to the uncontrolled cell growth: the hallmark of cancer.

Most experiments in this study were done using the MCF-7 breast cancer cell line. A short description of the duration of cell cycle phases in MCF-7 cells is given below (Wang S. et al., 1998):

Doubling time - 52 hours 
Duration of $\mathrm{G}_{1}-32$ hours

Duration of S - 15 hours

Duration of $\mathrm{G}_{2} / \mathrm{M}-5$ hours

\subsection{Cell cycle dysregulation and differentiation therapy}

Alteration in the components of the cell cycle machinery and checkpoint regulation pathways occur in most human tumors. It is found that in tumor cells genes that restrain cell division (tumor suppressor genes) are defective, while those that promote division (oncogenes) become more active. For example, loss of $\mathrm{pRb}$ tumor suppressor function leads to abnormal proliferation as a result of the deregulation of the E2F transcription factor (Nevins, J. R., 1998). In humans, inactivation of $\mathrm{pRb}$ is most commonly observed in retinoblastomas, osteosarcomas, carcinoid tumors, and small-cell lung cancer (Sherr C. J., 1996). Increased levels of cyclin D and cyclin E, amplification of the gene that encode CDK4 and CDK6 and deletion of p16 occur in a variety of human tumors, including breast and lung cancer, retinoblastoma and osteosarcoma (Zheng L. et al., 2001). The most frequently observed genetic lesion in human tumors is mutation in p53 tumor suppressor gene. p53 function might be disrupted also by alteration in cellular proteins, which modulate the expression, localization and activity of p53 protein (Momand J. et al., 1998). Regulation of c-myc oncogene expression is also critical for controlling cell proliferation. Alterations in c-myc gene expression due to chromosomal transformation, gene amplification, or point mutation in c-myc coding sequence have been demonstrated in Burkitt's lymphoma, myeloid and plasma cell leukemia, breast 
carcinoma, cervical carcinoma, small cell lung carcinoma, colon carcinoma, osteosarcoma, and glioblastoma (DePinho R. et al, 1991).

The detailed information about how cell cycle events are dysregulated in cancer gives us new opportunities to develop novel cancer therapy agents. The goal of therapy is to selectively kill cancer cells, and as cancer cells have a defective checkpoint mechanism, they may be more susceptible to chemotherapy than the normal cells.

One of the new approaches to cancer eradication is differentiation therapy. In humans, this technique was not used until it was shown that all-trans-retinoic acid could restore normal differentiation of the immature white blood cells of acute promyelocytic leukemia (Tallman M. S. et al., 1997). Differentiation therapy states that genes required for normal growth and differentiation are not necessarily lost during malignant transformation, but the regulation of these genes is often lost. Thus, even though there is a genetic alteration that is pushing cells through the cell cycle, perhaps there are other switches that can be used to stop this uncontrolled cell proliferation. In this type of therapy, the cells are treated with agents that would cause them to mature, thereby causing them to become less proliferative. Overall, differentiation therapy does not fix the genetic defect, but it modulates gene expression to control the cell cycle progression.

Well studied targets for tumor differentiation agents are histone deacetylases (HDACs). HDACs are responsible for the hydrolytic removal of acetyl groups from specific histone lysine residues, acetylation of which is catalyzed by histone acetyltransferases (M. Grunstein, 1997). Common profile of responses to the catalytic HDAC inhibitors includes histone hyperacetylation, elevated expression of the cyclin- 
dependent kinase inhibitor p21, cell cycle arrest and apoptosis (Vigushin D. M. et al., 2001).

Our knowledge of cell-cycle checkpoints offers hope for developing novel mechanism-based approaches to cancer treatment that will specifically target aberrant proliferation. 


\section{4. $\mathrm{pRb} / \mathrm{E2F} / \mathrm{Myc}$ pathway}

\subsection{Retinoblastoma family}

\subsubsection{Structural characteristics}

The retinoblastoma gene $(\mathrm{Rb})$ was the first tumor suppressor gene to be identified and it became the prototype for the study of human suppressor genes. Its absence or mutation is involved in the development of various types of human tumors (Nevins, J. R., 1998). The ability of $\mathrm{pRb}(\mathrm{Rb}$-gene product) to interact with other cellular proteins that affect transcription assures its role in regulating cell cycle, apoptosis and differentiation. Human pRb contains 928 amino acids (Figure 3). It is nuclear phosphoprotein with a half-life more than 8 hours. pRb belongs to the retinoblastoma gene family along with two other members: p130 and p107 which are structurally similar to pRb (Mayol X. et al., 1993). All three family members contain a so-called pocket domain, which is critical to the tumor-suppressor function of retinoblastoma protein and is the region of tumorigenic mutations. The pocket domain is highly conserved region, which is responsible for giving a particular conformation to the proteins, thus it sustains the proteins functional activity (Xiao B. et al., 2003). In this region p107 and p130 are more closely related to each other, than they are to $\mathrm{pRb}$. The pocket domain is subdivided into two conserved subdomains termed $\mathrm{A}$ and $\mathrm{B}$ and separating them is a spacer region. p107 and p130 have specific motif in spacer region that is not presented in $\mathrm{pRb}$, which enables them to form strong binding site for cyclin A/CDK2 and cyclin E/CDK 2 (Li Y. et al., 1993; Faha B. et al., 1992). p107 and p130 also share a homologous sequence near the aminoterminus that is absent in $\mathrm{pRb}$. The amino-terminal region of retinoblastoma proteins is still under investigation. It contains CDK phosphorylation sites, which may regulate Rb's activity 

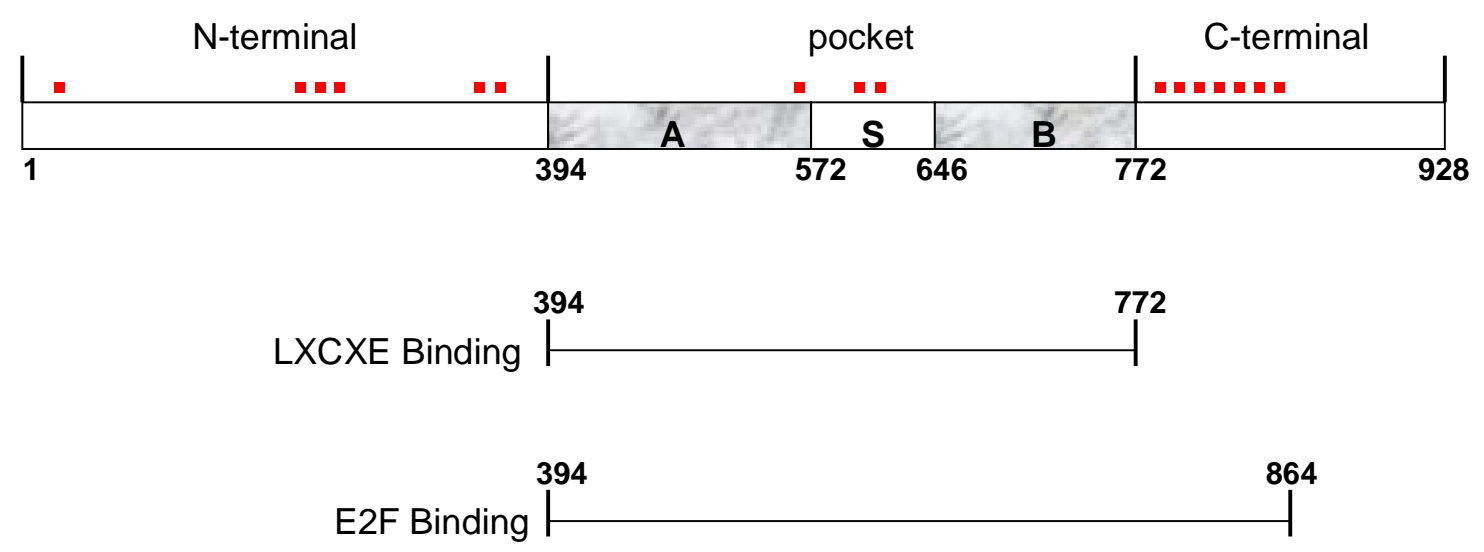

Figure 3. Putative regulatory features of retinoblastoma proteins. Red dots represent phosphorylation sites. 
during the cell cycle. The number of endogenous pRb-binding proteins contains LXCXE motifs. Specific residues in the pocket region of $\mathrm{pRb}$ interact with proteins that carry an LXCXE peptide sequence. Proteins that contain LXCXE-like sequence include chromatin remodeling proteins, such as HDAC-1 and HDAC-2 (Magnaghi J.L. et al., 1998). The LXCXE binding site is not the only binding site in the pocket region. The E2F transcriptional family and several oncoproteins, such as E1A and E7 lack LXCXE peptide sequence, but these proteins also bind $\mathrm{pRb}$ at a site that involves pocket and adjacent C-terminus (Lee I.O. et al., 1998). The analysis of $\mathrm{pRb}$ structure showed that it contains a number of phosphorylation sites, but the exact number of the residues that can be phosphorylated during the $\mathrm{G}_{1}$ phase is not yet clear.

\subsubsection{Functional characteristics}

The pocket proteins are differently expressed throughout the cell cycle. $\mathrm{pRb}$ is expressed steadily throughout the cell cycle, p130 is increased in arrested cells, whereas p107 expression is high during the S phase of the cell cycle (Tonini T. et al., 2002). Each of the $\mathrm{Rb}$ family proteins binds to and modulates the activity of the E2F family of transcription factors (Figure 4). p130 is associated with E2F-4 and E2F5. p130 and E2F-4 is the most abundant E2F complex found in resting or quiescent cells and is thought to be a repressor complex. pRb forms complexes with E2F-1, E2F-2, E2F-3 and E2F-4. p107 is found to form complex with E2F-4 and E2F-5. Retinoblastoma family members demonstrate cell growth suppressive properties between the $\mathrm{G}_{1}$ and $\mathrm{S}$ phases of the cell cycle. This negative control of the cell cycle is mostly due to the inactivation of transcription factors. All three proteins are regulated by cyclinc events of phosphorylation 


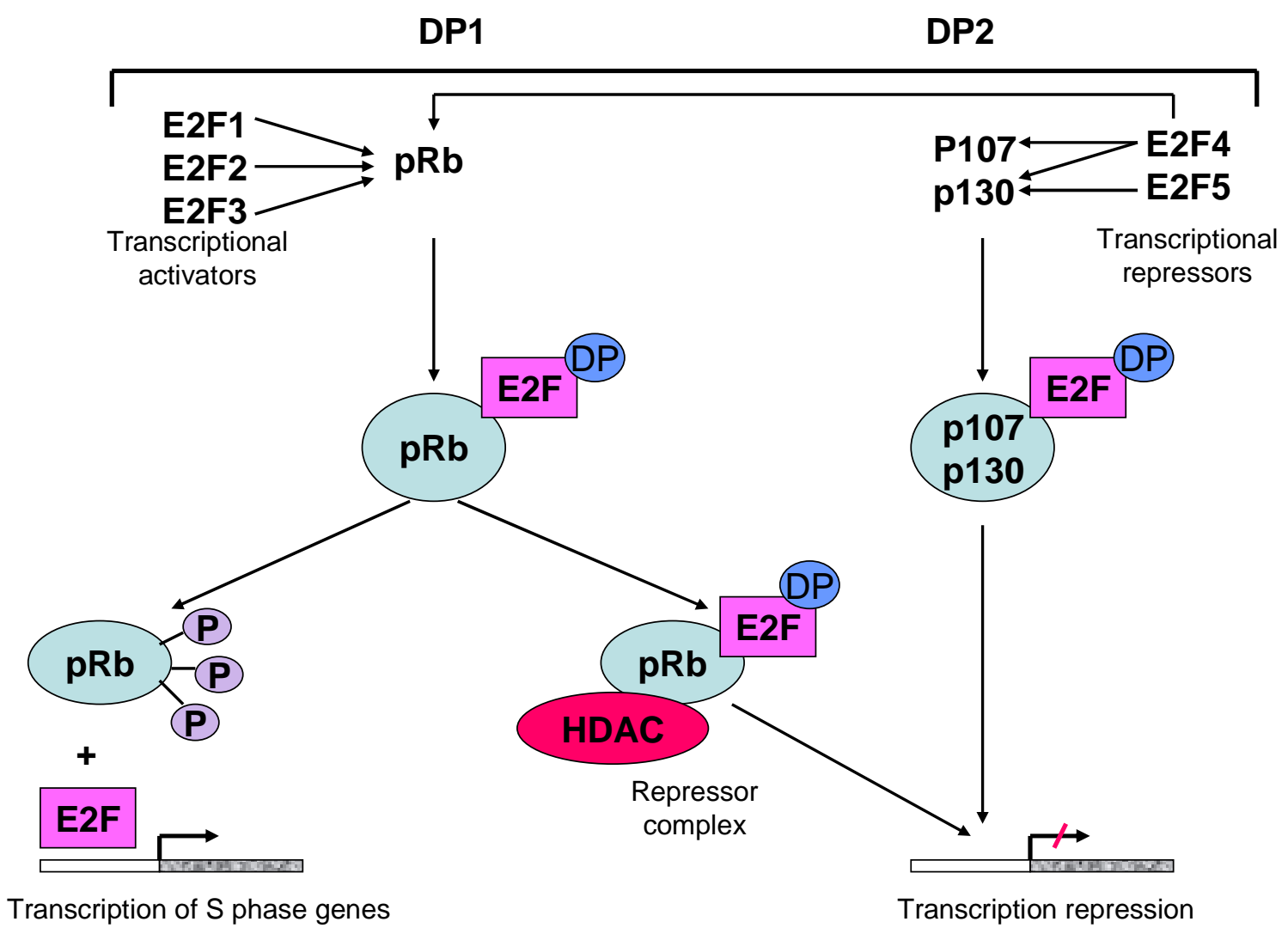

Figure 4: General scheme of E2F actions on transcriptional activity. 
and dephosphorylation. $\mathrm{pRb}$ is thought to function as the guardian of the $\mathrm{G}_{1} / \mathrm{S}$ phase transition. $\mathrm{pRb}$ arrests cells in $\mathrm{G}_{1}$ by binding to the members of E2F/DP family of transcription factors and inhibiting their activity. Phosphorylation of $\mathrm{pRb}$ is in the cell cycle dependent manner, and it leads to the release of free, transcriptionally active E2F. Subsequent activation of E2F-responsive genes during late $G_{1}$ seems to be enough to commit cells to start DNA replication. pRb phosphorylation is mediated by cell cycledependent kinase complexes Cdk4/Cdk6-cyclin D and Cdk2-cyclin E. Interestingly, phosphorylation of specific $\mathrm{pRb}$ phosphoacceptor sites may modulate biochemical activities of the protein. For example, phosphorylation of Ser608, Ser621 disrupts the binding of $\mathrm{pRb}$ to E2F, whereas phosphorylation of Thr821 and Thr826 affects the binding of $\mathrm{pRb}$ to LXCXE proteins. Present recent studies also suggest that certain $\mathrm{pRb}$ phosphoacceptor sites are preferentially phosphorylated by specific cyclin/CDK complexes. For example, Ser780, Ser807, Ser811 and Ser795 are phosphorylated by cyclin $\mathrm{D} / \mathrm{CDK} 4$, whereas Thr821 is preferentially phosphorylated by cyclin E/ CDK2 complexes (Knudsen E. S. et al., 1996; Knudsen E. S et al., 1997; Zarkowska T. et al., 1997). It is important to mention, that the phosphorylation state of a given protein depends on the ratio of protein kinase and phosphatase activities. This ratio is crucial for proper cell cycle regulation, because at times, dephosphorylation of CDK substrates may be necessary to ensure an orderly cell cycle. There are four prototypes of mammalian Ser/Thr-specific protein phosphatases: PP1, PP2A, PP2B and PP2C. PP1 was identified as the phosphatase responsible for the dephosphorylation and thus, activation of $\mathrm{pRb}$ (Durfee T. et al., 1993). PP2A specifically associates with $\mathrm{p} 107$, leading to the subsequent dephosphorylation of p107 (Voorhoeve P. M. et al., 1999). Another 
mechanism of $\mathrm{pRb}$ mediated repression of growth is associated with HDACs. $\mathrm{pRb}$ can bind at least two members of HDAC family, HDAC1 and HDAC2. HDAC-1 preferentially binds to the active, hypophosphorylated form of $\mathrm{pRb}$. Furthermore, E2F-1 binds this complex, creating a trimeric complex. Thus, this complex can be recruited to the E2F-1 responsive S-phase-specific promoters. HDAC then deacetylates the nucleosomes surrounding the promoter, induces changes in chromatin conformation, and prevents transcription factors access to their binding sites. Prior to $G_{1} / S$ transition, $p R b$ phosphorylation leads to the dissociation of E2F/pRb/HDAC repressor complex (Brehm A. et al., 1999).

$\mathrm{pRb}$ is not only a growth suppressor gene, it also exhibit anti-apoptotic properties. Loss of $\mathrm{pRb}$ function results in release of free E2F, which in its turn is targeting $\mathrm{p} 19$ (the alternate reading frame encoded by the p16INK4a locus). Increase in $\mathrm{p} 19$, which function is inhibition of MDM2-mediated turnover of p53, leads to an increase in p53 and apoptosis (Morgenbesser S. D. et al., 1994). The role of p107 and p130 in apoptosis is not defined yet.

The retinoblastoma family is involved in cellular differentiation. Several studies demonstrate an interaction between the retinoblastoma family protein and differentiationspecific transcription factors, such as MyoD and HBP1 (Yee A. S. et al., 1998). All three retinoblastoma proteins are highly expressed in some terminal differentiation cells. The ability of $\mathrm{pRb}$ to induce cellular differentiation is due to the fact that $\mathrm{pRb}$ forms complexes, and subsequently modulates various specific transcription factors.

In the next section the best-studied binding partner of retinoblastoma proteins the E2F family of transcription factors are discussed. 


\subsection{The E2F transcription factors}

E2F transcription factor plays a key role in cell proliferation, as it links the activities of the cell cycle machinery with the transcriptional regulation of genes required for S-phase entry, such as CDC6, as well as genes regulating cell cycle, such as cdc25A, cyclin E, E2F-1, pRb, B-myb and c-myc. E2F DNA-binding sites (TTTC/GG/CCGC/G) are found in the promoters of those genes (Dyson N. et al., 1998). In addition to regulating S-phase entry, E2F factors are involved in cell growth inhibition, differentiation, apoptosis and oncogenic transformation.

\subsubsection{The E2F family}

There are two distinct groups of genes that have been identified as components of E2F transcriptional activity: E2Fs (E2F1-E2F6) and the DPs (DP1 and DP2). Protein products from these two groups heterodimerize and give rise to all possible combinations of E2F-DP complex. It is established that E2F binds DNA in a DP-dependent manner. Heterodimerization not only improves E2F ability to bind DNA, it also increases pRb/E2F complex stability (Helin K. et al., 1993). DNA-binding domain is found in the amino terminus, and represents the area of greatest homology between E2Fs (E2F1E2F5). The DP dimmerization domain is adjacent to the DNA-binding domain. The carboxy termini of E2F1- E2F5 contain the defined transcriptional activation domain. There is a third conserved regions between the different E2Fs, which lays between DP dimerization and transcriptional activation domains, named Marked box, but its function is unknown. E2Fs are divided into three subgroups. E2F1, E2F2 and E2F3 are known as 
transcriptional activators with maximal accumulation at the $\mathrm{G}_{1} / \mathrm{S}$ boundary. These E2Fs are highly homologous in the DNA binding domain, DP dimerization and pRb biding domains and are similar in the ability to preferentially interact with $\mathrm{pRb}$ but not with p130 or p107. The E2F binding to pRb-family is mediated by a short, highly conserved domain near the carboxyl terminus of the E2F proteins. This binding domain overlaps with the transactivation domain. The amino termini of E2F1-E2F3 contains an additional region of homology not found in E2F4 or E2F5. This region binds cyclin A protein (Krek W. et al., 1994). Overexpression of any member of this subgroup is sufficient to induce resting cells to re-enter the cell cycle. The second group consists of E2F4 and E2F5. Members of this group bind all three $\mathrm{Rb}$ family members but appear to be primarily repressors of E2F-responsive genes. E2F6 is the only member of the third subgroup. It also acts as a transcriptional repressor but through pocket-protein-independent mechanism, because it lacks carboxy-terminal sequences. (Trimarchi J. M. et al., 1998). The expression of the various E2F family members differs during the cell cycle. The E2F1 and E2F2 levels are usually increased at the $\mathrm{G}_{1} / \mathrm{S}$-phase boundary. E2F3 and E2F5 expression levels rise in early-to-mid $\mathrm{G}_{1}$ and do not increase after cell enters $\mathrm{S}$ phase (Slansky J. E. et al., 1996). E2F-4 expression is slightly increased in mid $\mathrm{G}_{1}$, but it is constitutively expressed during all cell cycle phases, even in growth arrested cells (Sardet C. M. et al., 1995).

\subsubsection{Regulation of E2F factors by the Rb family of pocket proteins}

The activity of E2F factors are regulated through the association with members of $\mathrm{Rb}$ family. Pocket protein binding inhibit the transcriptional activity of E2F factors by 
masking the transcriptional activation domain, and in some cases, converts E2F factors to repressors of transcription. Several studies demonstrated a correlation between the ability of $\mathrm{Rb}$ to arrest cells in the $\mathrm{G}_{1}$ phase and to bind E2F (Qian Y. C. et al.,1992). E2F family members interact with specific pocket proteins in vivo. E2F-1, E2F-2 and E2F-3 associate exclusively with pRb. E2F-4 associates with all three of the pocket proteins. E2F-5 associates only with p130 protein. The presence of E2F-pocket complexes varies in the cell cycle-regulate manner. E2F binding can be inhibited by the phosphorylation of $\mathrm{pRb}$, because hypophosphorylated $\mathrm{pRb}$ has low affinity for E2F. Release of free E2F leads to the activation of E2F-dependent transcription of several S-phase entry genes, such as c-myc, cdc25A, cyclin E. Association of E2F with Rb is not the only event that contributes to the inactivation of E2F in S phase. Free E2F-1 and E2F-4 are degraded by the ubiquitin-proteosome pathway (Hateboer et al, 1996).

It has been found that association of pocket proteins with E2F factors can also result in the formation of transcriptional repressor complexes. For example in B-myb and RB1 E2F DNA-binding site functions as negative regulatory element (Johnson D. G. et al., 1994). Repression by pocket proteins involves the association of other proteins in addition to E2F factors, such as BRG1 and HDAC1. Those proteins are involved in remodeling of chromatin structure (Brehm A. et al., 1998; Dunaief J. L. et al., 1994). What factors play role in determining whether a given E2F site will function as a positive or negative regulatory element is at present unclear. 


\subsubsection{Control of apoptosis by E2F-1}

Overexpression of E2F-1 can induce a cell to undergo programmed cell death or apoptosis (Wu X. et al., 1994). The p53 protein is a key player in cellular decision to either arrest the cell cycle, or to commit to cell death. In p53-null mouse embryo fibroblasts, E2F-1 is much less efficient at inducing apoptosis. E2F-1 induces the expression of $\mathrm{p} 19$, which negatively regulates $\mathrm{Mdm} 2$, which in its turn negatively regulates p53 (DeGregori J. et al., 1997). This pathway establishes direct connection between E2F-1, p53 accumulation and apoptosis. E2F-1 can also induce apoptosis in a p53 independent manner, by inducing specific expression of Apaf1. Apaf1 in combination with cytochrome $\mathrm{C}$ and the caspase 9 protease forms the so-called apoptosome, which activates the downstream caspase proteases: the final effectors of cell death (Moroni M. C. et al., 2001).

$\mathrm{E} 2 \mathrm{~F}$ is one of the regulators of c-myc gene transcription. The function of Myc, cmyc gene product, as a downstream effector of E2F is discussed in next section.

\subsection{The c-myc transcription factor}

\subsection{1. c-myc transcription factor: regulation of the cell cycle, cellular differentiation and apoptosis}

The myc family of proto-Oncogenes includes three genes: c-myc, N-myc and Lmyc, which encode related proteins. It is well recognized that altered c-myc expression is involved in a wide variety of human tumors including breast, colon, and cervical carcinomas, osteosarcomas, glioblastomas and myeloid leukemia (Marcu K., et al., 1992; Spencer C., et al., 1991). Myc is a transcription factor of the Basic- helix - loop - helix - 
leucine zipper (bHLH-Zip) family. It dimerizes with another bHLH-Zip protein, Max, to bind the specific DNA sequence CACGTG (the E-box). Binding of Myc-Max heterodimers to the E-box sequences leads to the transactivation of Myc target genes. Max also forms heterodimers with the bHLH-Zip proteins Mad or MXI-1. These alternative dimers lack transactivation function, and may block the biological effect of Myc, by competing for the same binding site (Ayer D. E. et al., 1993). A number of Myc target genes were identified, such as genes that encode cdk-4 and cdc25A phosphatase proteins (Hermeking H. et al., 2000; Galaktinov K. et al., 1996).

Like E2F, the Myc protein has also been shown to play a critical role in the control of cell proliferation. In quiescent cells, c-myc expression is almost undetectable, but as a cell enters $G_{1}$ there is a transient burst in Myc protein expression, which declines to low steady-state levels in proliferating cells (Kelly K. et al., 1984). Several studies show that induction of c-myc expression following serum stimulation of quiescent cells is an important step towered the transition from $\mathrm{G}_{0}$ to $\mathrm{G}_{1}$ phase in nontransformed cells (Shichiri M. et al., 1993).

In addition to a role of Myc in cell proliferation control, it plays an important role in cellular differentiation. Downregulation of Myc expression is essential for terminal differentiation and withdrawal from the cell cycle (Griep A. E. et al., 1988).

Similar to the Rb/E2F pathway, Myc expression couples cellular proliferation with the induction of apoptosis under the conditions where survival growth factors are limited. Myc-induced apoptosis involves the induction of p19, inhibition of MDM2, and elevated p53 expression (Zindy F. et al., 1998). 


\subsubsection{Connection between Myc and Rb/E2F pathway}

Myc and E2F transcription factors share a number of functional properties, such as the ability to induce quiescent cells to enter the cell cycle and progress into $\mathrm{S}$ phase and to control the cell fate by activating p53 dependent apoptosis. Two E2F binding sites are located on the c-myc promoter and it has been recently shown that E2F activity is required for the ability of Myc to stimulate quiescent fibroblasts to progress into S phase (Leone G. et al., 2001). Furthermore, Myc overexpression has also been reported to induce E2F DNA binding activity (Jansen-Durr P et al., 1993), and directly contribute to the activation of E2F-1, E2F-2 and E2F-3 genes (Leone G. et al., 1997).

Most likely, Myc-mediated induction of CyclineD/Cdk4 or Cyclin E/cdk2 leads to the phosphorylation and inactivation of $\mathrm{Rb}$ family members, with subsequent release of free E2F transcription factor.

\section{Cellular redox regulation}

\subsection{ROS formation and its role in signaling pathways}

Formation of reactive oxygen species (ROS) is a consequence of aerobic metabolism, when cells are constantly engaged in redox reactions where electrons are exchanged between $\mathrm{O}_{2}, \mathrm{~N}_{2}$ and cellular components. When ROS levels exceed the antioxidant capacity of a cell, a condition known as oxidative stress occurs. Excessive ROS can lead to the damage of cellular components, such as lipids, proteins, and DNA ( Figure5). Thus, it is generally believed that accumulation of ROS, which include hydrogen peroxide $\left(\mathrm{H}_{2} \mathrm{O}_{2}\right)$, supreoxide anion, and hydroxyl radicals leads to initiation of 
numerous pathologies, including tissue ischemia and reperfusion, cancer, diabetic vasculopathy, atherosclerosis, Alzheimer's disease, and pulmonary fibrosis (Finkel T. et al., 2000; Mates J., M. et al., 1999; Davies K., J. et al., 2000). To defend against oxidative damage induced by ROS, a series of enzymatic (superoxide dismutase, catalase, glutathione peroxidase) and non-enzymatic (glutathione, $\alpha$-tocopherole, ascorbate) antioxidant defenses have evolved that neutralize ROS. However, formation of ROS is not always associated with cell damage. It is now clear that ROS have a cell signaling role in numerous of biological systems. ROS are considered as a potential signaling molecules because they are: 1) produced by the cells upon certain stimulation; 2) have an action in the cell which produces it or a nearby cell; and 3) is removed in order to turn off, or reverse the signal (Hancock J., T. et al., 2001).

Several enzymes are potentially able to generate ROS: nicotinamide adenine dinucleotide (NADH) (or NADPH) oxidase, xanthine oxidoreductase, organelles containing electron transport system, such as mitochondria, and preoxidases. NADPH oxidase complex is now recognized as a primary source of ROS (Figure 5). NADPH oxidase is a multisubunit complex that contains the two subunits of membrane-bound cytochrome b-558 (p22-phox and gp91-phox), and three cytosolic proteins (p40-phox, p47-phox, and p67-phox). Two small G-proteins are also associated with NADPH oxidase: Rac and Rap. (Honckock J. T. et al., 2001). Rac mediates the association of the p47-phos and p67-phox on the cytosolic side of the plasma membrane whereas Rap is involved in the regulation of association with the cytochrome b component (Gabig T. G. et all, 1995). NADPH oxidase catalyses one-electron reduction of molecular oxygen, with electron supplied by NADPH. Formed superoxide is further reduced to hydrogen 
peroxide. Superoxide may also react with nitric oxide to form peroxynitrite. Therefore, under the physiological conditions, once superoxide is formed, a cascade of ROS production is likely. Certain ROS species (hydroxyl radical, peroxynitrite) cause direct cellular damage. Other oxygen species (superoxide anion, hydrogen peroxide) play an important role in regulating the cellular redox potential.

\subsection{Cellular redox potential}

Redox potential $\left(\mathrm{E}_{\mathrm{c}}\right)$ is a physical property that determines the ease with which electrons transfer among all intracellular components. Glutathione is the primary buffer of intracellular redox status. A good estimate of $E_{c}$ can be calculated from the ratio of Glutathione (GSH)/Glutathione disulfide (GSSG). The Nernst equation gives the redox potential in terms of GSH and GSSG concentrations (Hoffman A. et al., 2001):

$$
\mathrm{E}=\mathrm{E}_{0}+30 \log \left\{[\mathrm{GSSG}] /[\mathrm{GSH}]^{2}\right\} \text {, where } \mathrm{E}_{0} \text { is the standard potential of the }
$$
GSH/GSSG couple (-0.24V) (Jones D. P. et al., 2002).

GSH, a tripeptide ( $\gamma$-glutamylcysteinylglycine) with a free thiol group, is a major antioxidant in human tissues. Glutathione synthase (GS) is an enzyme that synthesizes GSH de novo from amino acid precursors. Exogenous precursors for GSH (Nacetylcysteine) reduces $\mathrm{E}_{\mathrm{c}}$ by this route. The reaction between GSH and cytoplasmic oxidants produces GSSG. When mammalian cells are exposed to oxidative stress, the ratio of GSH/GSSG decreases and redox potential rises ( $E_{c}$ will become less negative). The GSSG is later recycled to GSH by reduction by NADPH. This reaction is catalyzed by glutathione reductase (GR). Changes in redox status of the cells affect cellular proliferation, differentiation and apoptosis. 


\subsection{Modulation of the cell cycle and differentiation by cellular redox potential}

Changes in redox potential may lead to changes of intracellular signals (Figure 5) that mediate cell proliferation, differentiation, apoptosis and mitogens-activated protein kinase (MAPKs) cascade (Wang S. et al., 1998; Tardif M. et al., 1998). The mechanisms that couple those cellular events and redox potential of the cells are studied intensively.

Cysteine containing proteins can serve to couple cellular redox status and protein function, because they can form disulfide bonds (S-S) between two $-\mathrm{SH}$ groups of neighboring cysteine residues, in a sufficiently oxidizing environment. These bonds are important for stabilizing three dimensional structures of the proteins. When redox potential of the cell is low, disulfide bonds can break, and the new ones are not formed. It has been reported by several laboratories that cellular redox potential is involved in physiological cellular signaling and cell cycle regulation. For example, GSH depleting agent, diethylmaleate, cause oxidative stressing $\mathrm{HeLa}$ cells, which leads to $\mathrm{pRb}$ hypophosphorylation and $\mathrm{G}_{1}$ cell cycle arrest (Esposito F. et al., 2000). Interestingly, the cell cycle arrest in $\mathrm{G}_{1}$ as a response to the depletion of intracellular $\mathrm{GSH}$, can be reversed by GSH precursors, such as N-acetylcysteine (Hoffman A. et al., 2001). In light of the above Hoffman et al proposed a model for redox dependent cell cycle arrest. In this model mild oxidative stress resulting in decreased GSH concentration prevents $\mathrm{pRb}$ phosphorylation with subsequent $\mathrm{G}_{1}$ arrest. Similar results were obtained by L. Cicchillitti et al. They demonstrated that oxidative stress induces PP2A-dependent dephosphorylation of the pocket proteins pRb, p107, and p130 (Cicchillitti L. et al, 2003). There are studies demonstrating the involvement of redox systems in cell proliferation. 


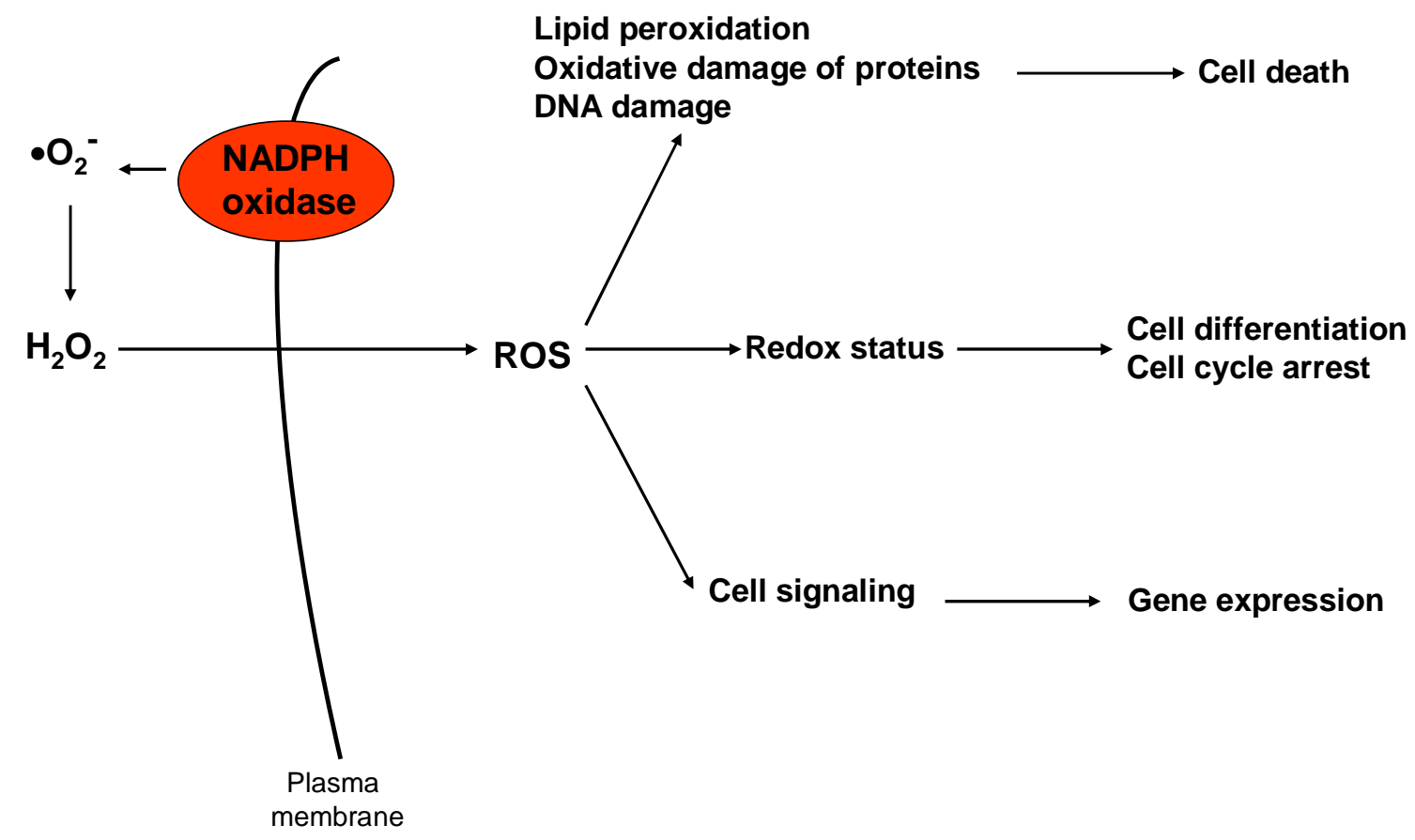

Figure 5. Potential role of ROS in cells. 
Activation of membrane redox system results in stimulation of growth in cells, whereas the inhibition of membrane redox activity causes retardation of cell proliferation (Morre D. J. et al., 1998). Furthermore, several reports have shown that MAPKs are activated by ROS, which could lead to modulation of gene expression (Tardif M. et al., 1998).

The goal of this study was to investigate mechanism of action of NSC3852 differentiation inducing quinoline identified by screening of quinoline ring-containing compounds. 


\section{Research objectives}

Previous studies in our laboratory demonstrated that quinidine, a quinoline ring containing compound, caused mid $\mathrm{G}_{1} / \mathrm{G}_{0}$ arrest, inhibited proliferation, negatively regulated HDAC and stimulated differentiation in MCF-7 breast tumor cells. Extended studies showed most but not all quinoline antimalarials caused some degree of growth inhibition and differentiation (Oil Red O assay) in breast cancer cells (Johnson D. N. et al, 1999).

\section{The first goal of this project was to find a more potent compound to induce a more differentiated phenotype in breast cancer cells in vitro.}

1. We hypothesize that the quinoline aromatic ring system contains a property that promotes differentiation in breast tumor cells. The MTS (3-(4,5dimethylthiazol-2-yl)-5-(3-carboxymethoxyphenyl)-2-(4-sulfophenyl)-2Htetrazolium) assay, a method that we used to measure relative viable cells in control versus treated samples, to assess the growth inhibiting properties of twenty three quinoline ring compounds. $\mathrm{IC}_{50}$ values of the compounds were determined. Using MTS $\mathrm{IC}_{50}$ levels of each compound, we found five quinoline ring - containing compounds induced accumulation of $\mathrm{G}_{0}$ cells and differentiation (Oil Red O) in MCF-7 cells at MTS $\mathrm{IC}_{50}$ concentrations lower than the $\mathrm{IC}_{50}$ concentration of quinidine. 
2. We tested whether DNA damage or/and apoptosis contributed to the growth inhibition induced by quinoline ring - containing compounds. We identified NSC3852, a compound that caused DNA damage and induced apoptosis in breast cancer cells.

Based on the data obtained from those experiments we chose NSC3852 as our lead compound for further investigation.

\section{The second goal of the project was to identify mechanism by which NSC3852 arrests cell growth and induces $\mathbf{G}_{0}$ accumulation.}

1. Hypophosphorylated $\mathrm{pRb}$ prevents cycle progression (Nevins J. R.,1998). We hypothesized that cell cycle arrest caused by NSC3852 results from $\mathrm{pRb}$ hypophosphorylation. Our results indicated that NSC3852 caused accumulation of the hypophosphorylated form of $\mathrm{pRb}$. We predicted that hypophosphorylation of $\mathrm{pRb}$ would cause suppression of E2F-1 activity as well as downregulation of its downstream product Myc protein. Our results indicate that NSC3852 downregulated levels of E2F-1 and suppressed its activity as transcription factor. NSC3852 also downregulated levels of Myc protein and suppressed its activity as a transcription factor. 
2. Elevated redox potential causes the accumulation of $\mathrm{pRb}$ protein in its hypophosphorylated form (A. Hofman et al., 2001). We hypothesized that redox status contributes to action of NSC3852 on pRb phosphorylation. This hypothesis predicts $\mathrm{N}$-acetylcysteine (NAC), a GSH precursor, will reverse the action of NSC3852 pRb phosphorylation. Our results indicate that NAC reversed accumulation of hypophosphorylated $\mathrm{pRb}$, and reversed NSC3852 induced decrease in E2F-1 and Myc protein levels.

3. NSC3852 induced DNA damage and apoptosis in MCF-7 cells. We tested the hypothesis that redox activity of NSC3852 resulted in induction of DNA damage and apoptosis in MCF-7 cells. We predicted that NAC will reverse the DNA damage and apoptosis induced by NSC3852 in breast cancer cells. Our results showed that cells pretreated with NAC were protected form NSC3852 induced DNA damage and apoptosis.

4. NSC3852 suppressed growth of MCF-7 cells. We hypothesized that NAC reverses the effect of NSC3852 on cell growth. Cell growth experiments showed that NAC only partially reversed the effect of NSC3852 on cell growth. 
5. We hypothesized that NAC sensitive hypophosphorylation of $\mathrm{pRb}$ is necessary for the differentiation response induced by NSC3852 in MCF7 cells. Therefore, we tested whether accumulation of $\mathrm{G}_{0}$ cells induced by NSC3852 is reversed by NAC. Ki67 immunohistochemistry was performed. Results obtained from those experiments indicate that NAC only partially reversed the cell cycle arrest induced by NSC3852 in MCF7 cells.

6. Based on the fact that NSC3852 induced changes involve NAC responsive redox pathway we hypothesized that NSC3852 mediates ROS generation in MCF-7 cells. The electron spin resonance (EPR) spin trapping technique was used to examine free radical generation mediated by NSC3852 and the source of its production. Our results indicated that NADPH oxidase is responsible for NSC3852 mediated $\bullet \mathrm{O}_{2}{ }^{-}$generation.

7. NSC3852 induced an increased accumulation of $\cdot \mathrm{O}_{2}{ }^{-}$in the cells, thus we predicted that the GSH/GSSG ratio in the cells exposed to NSC3852 should also be altered. Obtained data indicated that superoxide formation induced by NSC3852 changed the redox status of the cells (GSH/GSSG ratio).

8. Based on the obtained results we proposed model of NSC 3852 mechanism of action. 


\section{MATERIALS AND METHODS}

\section{Materials}

\subsection{Cells}

MCF-7 cells and MDA-231 cells were provided by Dr. Marc Lippman (Lombardi Cancer Center, Georgetown University). MCF-10A cells were obtained from American Type Culture Collection.

\subsection{Chemicals}

All National Service Center (NSC) compounds were kindly provided by Dr. Robert Schultz (Drug Synthesis \& Chemistry Branch, Developmental Therapeutics Program, Division of Cancer Treatment and Diagnosis, National Cancer Institute, Bethesda, MD). Quinidine-HCl was purchased from Sigma Chemical Company (St. Louis, MO). NAcetyl-L-cysteine (A-7250) was obtained from Sigma.

\subsection{Plasmids}

The pE2F-TA-Luc, pMyc-TA-Luc and control plasmid, TA-Luc were purchased from Clontech Laboratories, Inc. (Palo Alto, CA). 


\subsection{Antibodies}

The $\mathrm{Rb}$ (C-15, sc-50) antibody, which reacts with phosphorylated and nonphosphorylated forms of Rb p110 of mouse, rat and human origin was purchased from Santa Cruz Biotechnology (Santa Cruz, CA). Anti-E2F-1 (\# 05-379), clones KH20 \& KH95 (mixed mouse monoclonal $\mathrm{IgG}_{2 \mathrm{a}}$ ) with epitopes mapped to amino acids 1-89 and 342-386, respectively were purchased from Upstate Biotechnology (Lake Placid, NY). E2F-2 (L-20, sc-632), E2F-3 (N-20, sc-879), E2F-4 (RK-13, sc-551), E2F-5 (E-19, sc999), p130 (C-20, sc-317), p107 (SD9, sc-250), HSP70 (K-20, sc-1060) were also purchased from Santa Cruz Biotechnology (Santa Cruz, CA). The HDAC1 (PA1-860) antibody was obtained from Affinity BioReagents (Golden, CO). The Ki-67 (MIB-1, Ab-1) antibody was obtained from Oncogene Science (Cambridge, MA). A peroxidaseconjugated anti-goat IgG (sc-2020), goat anti-mouse IgG (sc-2005), goat anti-rabbit IgG (sc-2004) were purchased form Santa Cruz Biotechnology (Santa Cruz, CA) and used as secondary antibodies for Western blots. Biotinylated anti-mouse IgG (H+L) (BA-2000, Vector Laboratories, Inc.) was used as the secondary antibody for Ki-67 immunohistochemistry. 


\section{Methods}

\subsection{Tissue culture}

MCF-7 cells (passage \#35-50) and MDA-MB-231 cells were maintained in Dulbecco's modified Eagle's medium (DMEM) (BioWhittaker, Walkersville, MD) supplemented with $10 \%$ heat-inactivated fetal bovine serum (FBS) (HyClone laboratories, Inc, Logan, Utah) and $0.04 \mathrm{mg} / \mathrm{ml}$ gentamicin in a humidified atmosphere of $93 \%$ air, $7.0 \% \mathrm{CO}_{2}$ at $37^{\circ} \mathrm{C}$. Experiments were performed in DMEM supplemented with 5\% FBS. Cells were passaged every 4-5 days at a 1:5 (MCF-7) or 1:10 (MDA-231) ratio. MCF-10A, immortalized human mammary epithelial cells, (passage \#9-20), were maintained in Mammary Epithelial Cell Growth Medium (MEGM) (Bio Whittaker) according to the directions from the supplier and passaged weekly at a 1:4 ratio. All the cells were counted using a hemocytometer and cell viability was determined by trypan blue exclusion ( $0.02 \%$ trypan blue).

\subsection{MTS (3-(4,5-dimethylthiazol-2-yl)-5-(3-carboxymethoxyphenyl)-2-(4- sulfophenyl)-2H-tetrazolium) Assay.}

The MTS metabolism was used as an index of cell viability. MCF-7, MCF-10A or MDA-MB-231 cells were plated at 4000 (MCF-7), 4000 (MCF-10A), 500 (MDA-MB231) cells/well in a 96-well plate in $225 \mu 1 \mathrm{DMEM} / 5 \%$ FBS or MEGM (MCF-10A). Cells were left to attach for 24 hours and drugs were added. After 24 hours of treatment, the medium was removed by aspiration and $100 \mu 1$ of fresh DMEM/5\% FBS or MEGM + $20 \mu 1$ Cell Titer 96 (Promega, Madison, WI) was added. Cells were incubated for 2 hours 
at $37^{\circ} \mathrm{C}$. Conversion of MTS reagent to a colored formazan product was measured by an increase in absorbance at $490 \mathrm{~nm}$ using a Spectra Max 340pc plate reader (Molecular Devices, Sunnyvale, CA). Under our assay conditions the MTS metabolism assay was linear for 3 hours.

\subsection{Oil-Red O assay}

Cells $\left(2.5 \times 10^{5}\right.$ cells $/ 35 \mathrm{~mm}^{2}$ dish $)$ were plated on sterile glass cover slips in fresh growth medium (DMEM/5\%FBS +/- drugs). After the treatment, the cover slips were transferred into $60 \mathrm{~mm}^{2}$ glass dishes and $3 \mathrm{ml}$ of cell fixative solution $(10 \%$ formaldehyde and $2 \%$ calcium acetate in PBS (phosphate buffer saline: $137 \mathrm{mM} \mathrm{NaCl}$, $2.7 \mathrm{mM} \mathrm{KCl}, 4.3 \mathrm{mM} \mathrm{Na} 2 \mathrm{HPO}_{4} \times 7 \mathrm{H}_{2} \mathrm{O}, 1.4 \mathrm{mM} \mathrm{KH} \mathrm{HO}_{4}, \mathrm{pH}$ 7.3)) were added. The fixative was removed by aspiration after 3 minutes and $3 \mathrm{ml}$ of freshly made Oil-Red $\mathrm{O}$ working solution (Oil-Red $\mathrm{O}$ stock solution ( $0.5 \%$ Oil-Red O (Sigma) in $98 \%$ Isopropanol) diluted in water in a 3:2 ratio) were added. After 10 minutes of staining, cells were rinsed with water and counterstained with Mayer's hematoxylin solution (Fisher, Pittsburgh, PA) for 1 minute at room temperature. Cells were briefly dipped in $0.4 \% \mathrm{NH}_{4} \mathrm{OH}$, rinsed in distilled water, mounted with $50 \%$ glycerol solution (1:1 dilution of Glycerol and water), and then dried for 10 minutes. An Ortholux microscope (Ernst Leitz Wetzlar, Germany) (40x objective) was used to obtain images. 


\subsection{Ki-67 immunohistochemistry}

Cells $\left(2.5 \times 10^{6}\right.$ cells $/ 35 \mathrm{~mm}^{2}$ dish $)$ were plated on sterile glass coverslips in $3 \mathrm{ml}$ of DMEM/5\% FBS +/- drugs. At the end of the treatment (24 or 48 hours) the medium was removed by aspiration. Cells were fixed on the cover slips (10 minute incubation on ice) using $-20^{\circ} \mathrm{C}$ fixing solution $(50 \%$ acetone $/ 50 \%$ ethanol $)$. All the remaining steps were performed at room temperature. Cells were rinsed with working PBS (wPBS) solution (1x PBS, $0.15 \%$ bovine serum albumin). In order to block endogenous peroxidase activity, freshly made Blocking solution \#1 (1:100 dilution of $30 \% \mathrm{H}_{2} \mathrm{O}_{2}$ in methanol) was added to the cells for 15 minute. Cells were rinsed with wPBS, and then blocking solution \#2 was added for 30 minutes to block non-specific binding of antibodies. The blocking solution was removed and $500 \mu \mathrm{l}$ of Ki-67 antibody (1:50 dilution in wPBS) was added. (Cells used for the negative control remained in the blocking solution \#2). After one hour incubation, cells were rinsed with wPBS for 5 minutes and a secondary antibody (biotinylated anti-mouse IgG, 1:125 dilution in wPBS) was added for 30 minutes. The secondary antibody was removed by rinsing cells with wPBS for 5 minutes and B/A solution (Biotin-Avidin solution) was added. B/A was prepared 30 minutes prior to use by adding 1 drop of each Reagent A and B (PK-6100, Peroxidase Vectastatin Elite ABC kit, Vector Laboratories, Inc.). After 30 minutes in B/A solution, cells were rinsed with wPBS for 5 minute and a peroxidase substrate, DAB (750118, Research Genetics, Inc.) was added for 10 minutes. After that, cells were rinsed with wPBS and counterstained with Mayer's hematoxylin (Sigma) for 1-2 minutes to 
visualize cell nuclei. Coverslips were subsequently dipped in $0.4 \% \mathrm{NH}_{4} \mathrm{OH}$ solution in tap water, dipped in $60 \%$ and $90 \%$ ethanol, respectively, and finally mounted using Permount (Fisher Scientific, Pittsburgh, PA). Ki67 negative cells were visualized by light microscopy (40x objective, Ortholux microscope, Ernst Leitz, Wetzlar, Germany). Cells were individually assigned with negative or positive staining, and the Ki67 negative percentage of the cell population was determined by counting using Image-Pro Plus software (Media Cybenetics, Silver Spring, MD). In each coverslip, at least 500 cells were counted.

\subsection{Cell Death ELISA (enzyme-linked immunosorbent assay)}

The release of nucleosomal fragment into the cytoplasm during the early stages of apoptosis was quantified using the cell Death Detection ELISA ${ }^{\text {PLUS }}$ kit (Roche Molecular Biochemicals, \# 1774 425). Briefly, MCF-7 and MDA-MB-231 cells $\left(4 \times 10^{3}\right)$ were plated in triplicate into 96-well plates +/- drugs for 72 hours or 24 hours, respectively. After the treatment, cells were centrifuged for 10 minutes at $1000 \mathrm{rpm}$ and the supernatant was removed by inversion of the plate. The attached cells were resuspended in $200 \mu \mathrm{l}$ of lysis buffer (30 minutes) and centrifuged at $1000 \mathrm{rpm}$ for 10 minutes. Cell cytoplasmic fractions from each well were assayed in duplicate for the presence of nucleosomes according to the directions from the suppliers. Briefly a quantitative sandwich-enzyme-immunoassay-principle is applied to nucleosome detection using mouse monoclonal antibodies directed against DNA and histones, respectively. As a measure of the ability of each compound to induce apoptosis in MCF-7 and MDA-MB- 
231 cells, the nucleosome-enrichment fraction was calculated as the ratio of the absorbance (405 nm) of drug-treated cultures / solvent exposed cultures.

\subsection{Histone Deacetylase (HDAC) Fluorescent Activity Assay}

The HDAC Fluorescent Activity Assay (Drug Discovery kit cat \# AK-500, BIOMOL Research Laboratories, Inc. Plymouth Meeting, PA) was used to screen drugs for the ability to directly inhibit HDAC activity. This assay system measures histone deacetylase activity present in a commercial HeLa (human cervical cancer cell line) cell nuclear extract, which is rich in predominantly HDAC1 and HDAC2 activity and was used as the HDAC source. The HDAC substrate contains an acetylated lysine side chain. After incubation with the HeLa nuclear extract, HDAC-mediated deacetylation of the substrate sensitizes the substrate, and following addition of a developer agent, causes the conversion of deacetylated lysine to a fluorophore. Briefly, reactions were performed at room temperature in a 96-well microtiter plate. The potent HDAC inhibitor, trichostatin A $(35 \mathrm{nM})$, was used as a positive control. Diluted HeLa extract (15ul) +/- drugs were added into appropriate wells. Diluted substrate (25ul) was added to each well and mixed thoroughly; HDAC reactions were performed for 10 minutes. The developer (50ul) was added into each well of the microtiter plate to stop the HDAC reactions. The plate was incubated at room temperature for 10 minutes, and read in a microtiter-plate reading fluorimeter (CytoFluor 4000, PerSeptive Biosystems, Inc., Farmingham, MA) using an excitation at a wavelength in the range $350-380 \mathrm{~nm}$ and emission in the range $440-460 \mathrm{~nm}$ 


\subsection{Western Blotting}

Cells were plated $\left(2 \times 10^{6} / 60 \mathrm{~mm}^{2}\right)$ in $5 \mathrm{ml}$ DMEM / 5\% FBS culture medium. Cells were left to attach for 12 hours and drugs were added. After treatment, cell monolayers were rinsed with PBS and harvested by scraping in $100^{\circ} \mathrm{C}$ Western lysis buffer (1\% SDS, $10 \mathrm{mM}$ Tris, $\mathrm{pH} 7.4$ ). Cell lysates were collected by syringe in $100-150 \mu 1$, transferred into $1.5 \mathrm{ml}$ tubes, passed through the syringe three times, to reduce viscosity and heated to $100^{\circ} \mathrm{C}$ for 5 minutes to inactivate proteases. Supernatant solutions were collected by centrifugation in a microcentrifuge at $4^{\circ} \mathrm{C}$ for 5 minutes. Protein concentrations were determined using the BCA assay (bicinchonic acid, Pierce, Rockford, IL). Following the BCA assay, Dithiothreitol (DTT) and protease inhibitors were added to the final concentrations indicated: DTT (1 mM), PMSF (phenylmethylsulfonyl fluoride, $1.0 \mathrm{mM}$ ), aprotinin $(1 \mu \mathrm{g} / \mathrm{ml})$, and leupeptin $(1 \mu \mathrm{g} / \mathrm{ml})$. Protein samples containing $60-70 \mu \mathrm{g}$ of protein were diluted (4:1 ratio) in $5 \mathrm{X}$ Western sample buffer ( $0.3 \mathrm{M}$ Tris-HCl, $\mathrm{pH} 7.0$, at ration 1:5 Glycerol, 3M SDS, $100 \mu \mathrm{l}$ of saturated Bromophenol Blue solution, q.s. 10ml with water; $12.5 \mu 1$ of 2 -Mercaptoethanol/100 $\mu 1$ was added to the $5 \mathrm{X}$ buffer, fresh each time), incubated at $100^{\circ} \mathrm{C}$ for 3 minutes and then resolved on $10 \%$ acrylamide gels by electrophoreses at $100 \mathrm{~V}$. Proteins were transferred to polyvinylidene difluoride membranes (Invitrogen) at $25 \mathrm{~V}$ for 2 hours. Membranes were blocked at $4^{\circ} \mathrm{C}$, overnight in 3\% non-fat powdered milk/Tris buffered saline (TBS: $0.02 \mathrm{M}$ Tris-HCl, $\mathrm{pH}$ 7.5, $0.5 \mathrm{M}$ $\mathrm{NaCl})+0.05 \%$ Tween20 (TBST). Membrane were washed 3 times (5 minutes each wash) with room temperature Western washing solution ( $0.1 \%$ non-fat dry milk, $0.1 \%$ 
chick ovalbumin, $1 \%$ FBS, $0.2 \%$ Tween 20$)$. After the washes, membranes were incubated with primary antibody diluted in washing buffer for 3.5 hours (at room temperature on a rocker). Following primary antibody hybridization, membranes were washed 3 times, 5 minutes per each wash with Western washing solution followed by one 5-minute wash in TBST buffer. Membranes were hybridized with secondary antibody diluted in TBST buffer for 40 minutes using the same conditions as for the primary antibody. Membranes were washed 3 times (10 minutes each wash) with TBST. Signals were visualized by incubating the membrane with a chemiluminescent peroxidase substrate (Super Signal, Pierce, Rockford, IL) for 7 minute and exposing the membrane to film (Eastman Kodak Co., Rochester, NY). Signals were quantified using FluorChem (Alpha Innotech, San Leandro, CA) spot densitometry.

\subsection{Immunoprecipitation (IP)}

MCF-7 cells $\left(3.5 \times 10^{6} / 100 \mathrm{~mm}^{2}\right)$ were plated in DMEM / 5\% FBS culture medium. Cells were left to attach for 12 hours and drugs were added. After 24 hours cells were rinsed with ice-cold 1x PBS, harvested by scraping in pre-chilled Lysis Buffer (1\% NP40, 0.02M Tris, $\mathrm{pH} 8.0,0.135 \mathrm{M} \mathrm{NaCl}$, glycerol 1:10, 0.003M Sodium Vanadate) with

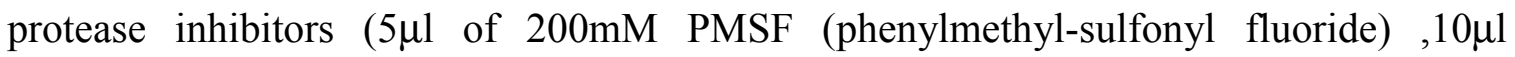
aprotinine, $2 \mu \mathrm{l}$ of $10 \mathrm{mg} / \mathrm{ml} \mathrm{leupeptin} / \mathrm{ml}$ of NP-40 buffer) and transferred to $1.5 \mathrm{ml}$ Eppendorf tubes. All the following steps were performed at $4^{\circ} \mathrm{C}$. Samples were incubated on ice for 10 minutes and then centrifuged for 20-30 minutes. The supernatant was collected and transferred to clean tubes. Aliquots were removed for the determination of 
protein concentration by BSA assay. Protein A/G beads $(20 \mu / 100-500 \mu \mathrm{g}$ of protein) were added and samples were rotated for 20 minutes at $4^{\circ} \mathrm{C}$. Antibodies were added for primary IP reaction and samples were rotated for three hour at $4^{\circ} \mathrm{C}$. Protein $\mathrm{A} / \mathrm{G}$ beads $(20 \mu 1 / 100-500 \mu \mathrm{g}$ of protein) were added for 1 hour. Samples were centrifuged and beads were washed with NP-40 buffer. Western Blot Sample Buffer was added, samples were heated to $100^{\circ} \mathrm{C}$ for 5 minutes to elute proteins and incubated on ice for 3 minutes. After 2 minutes of centrifugation (to pellet the beads) immunoprecipitates were run on SDSPAGE and immunoblotted with antibodies. Protein signals were visualized by incubating the membranes with a peroxidase substrate for 7 minutes to yield a chemiluminescent product, detected by exposure of the membrane to Kodak X-OMAT film.

\subsection{Reporter gene assay}

Transient transfection procedure. All plasmids used in this assay were purified using Qiagen DNA purification columns, according to the directions from the suppliers. MCF-7 cells $\left(2 \times 10^{6} / 60 \mathrm{~mm}^{2}\right.$ dish) were plated in 5ml DMEM / 5\% FBS medium. After 45-48 hours, when cells reached about 90\% confluency, cells were rinsed with 1xHBSS (Hank's Balanced Salt Solution) buffer and 2ml of Opti-MEM I medium (\# 31985-070, Invitrogen, Carlsbad, CA) were added, incubated for 40 minutes and then removed by

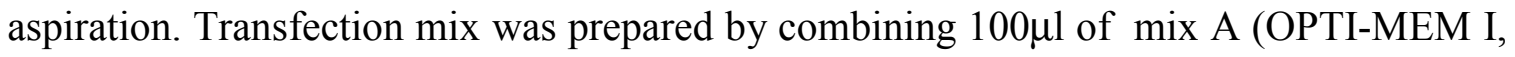
2.5 $\mu$ g plasmid DNA and Lipofectamine Plus (\# 11514-015, Invitrogen) reagent) and 110 $\mu 1$ of mix B (OPTI MEM I and 4 $\mu 1$ of Lipofectamine reagent (\# 18324-020, Invitrogen); mixes A and B were incubated separately for 20 minutes. Transfection was started by 
adding $200 \mu \mathrm{l}$ of transfection mix with $800 \mu \mathrm{l}$ of OPTI-MEM I to the cells. Transfection was carried out for 5-6 hours and was terminated by exchanging the medium with freshly made $5 \mathrm{ml}$ of DMEM / 5\% FBS culture medium (without antibiotic) +/- drugs.

Luciferase Assay. After 24 hours post-transfection, cells were harvested by scraping into ice-cold lysis buffer (25 mM Tris-phosphate, $\mathrm{pH} 7.8,1 \%$ Triton $\mathrm{X}-100,2$ $\mathrm{mM}$ EDTA, 10\% Glycerol). Cell lysates were transferred into $1.5 \mathrm{ml}$ Eppendorf microcenrifuge and centrifuged at maximal speed $\left(5\right.$ minutes, at $\left.4^{\circ} \mathrm{C}\right)$. Aliquots $(20 \mu \mathrm{l})$ were removed for determination of protein concentration by BCA assay. Supernatant solutions were transferred into clean tubes. Ice-cold luciferase sample buffer $(25 \mathrm{mM}$ glycylglycyl, $\left.\mathrm{pH} 7.8,15 \mathrm{mM} \mathrm{MgSO}_{4}\right)(250 \mu \mathrm{l})$ were mixed with cell extracts $(50 \mu \mathrm{l})$ in $12 \times 75 \mathrm{~mm}$ polypropylene culture tubes. The samples were warmed to $25^{\circ} \mathrm{C}$ and luciferase activity was measured using an Auto Luminat (LB 953, EG and G-Berthold) equipped with a dual injection system. ATP solution $(100 \mu \mathrm{l})(25 \mathrm{mM}$ glycylglycyl, pH

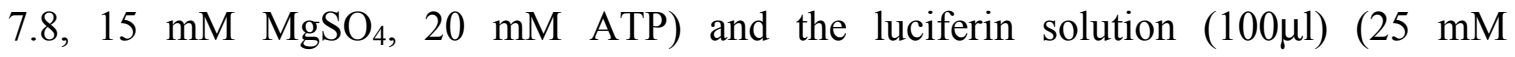
glycylglycyl, pH 7.8, $1 \mathrm{mM}$ luciferin) were automatically injected into each sample and the production of the light was measured. The same luminometer settings were used for each experiment: incubation temperature $=25^{\circ} \mathrm{C}$, reading time $=6$ seconds, injection amount $=100 \mu \mathrm{l}$. The relative light production obtained from $50 \mu 1$ of cell extracts were normalized to $200 \mu \mathrm{g}$ of cellular protein.

\subsection{Comet Analysis}

MCF-7 cells $\left(2 \times 10^{5} / 35 \mathrm{~mm}^{2}\right.$ dish $)$ were plated in $3 \mathrm{ml} \mathrm{DMEM} \mathrm{/} \mathrm{5 \%} \mathrm{FBS} \mathrm{culture} \mathrm{medium.}$ Cells were left to attach for 12 hours and the drugs were added. After 24 hours, cells were 
rinsed with ice cold PBS, harvested and counted. Cells were pelleted in a $15 \mathrm{ml}$ conical tubes by centrifugation (Sorvall GLC-2B centrifuge, Hoffman Estates, IL) for 5 minutes at $1200 \mathrm{rpm}$ (Sorvall GLC-2B), washed with $1 \mathrm{ml}$ ice cold PBS, centrifuged again and resuspended in ice cold PBS at $\left(1 \times 10^{5}\right.$ cells $\left./ \mathrm{ml}\right)$. The PBS cell suspension $(50 \mu \mathrm{l})$ was mixed with $500 \mu \mathrm{l}$ of $42^{\circ} \mathrm{C}$ low melting point agarose, spread evenly $(75 \mu 1)$ onto a Comet Slide (\# 4250-050-03, Trevigen, Gaithersburg, MD) and allowed to dry flat for 30 minutes at $4^{\circ} \mathrm{C}$ (protected from light). Slides were then immersed in prechilled lysis solution (\# 4250-050-01, Trevigen), incubated on ice for 45 minutes, and then transferred to freshly prepared alkali solution (300 mM NaOH, $1 \mathrm{mM}$ EDTA, $\mathrm{pH}$ 8.0) for 45 minutes at room temperature (protected from light). Slides were aligned equidistant from the electrodes of an electrophoresis apparatus and electrophoresed for $30 \mathrm{~min}$ at $1 \mathrm{~V} / \mathrm{cm}$ and $300 \mathrm{~mA}$. Slides were immersed in $70 \%$ ethanol for $5 \mathrm{~min}$ and then allowed to air dry overnight at room temperature. Slides were stained with $50 \mu$ l of SYBR Green stain (\# 4250-050-05, Trevigen, Gathersburg, MD) for 7 minutes and five drops of filtered antifade solution (20mg p-phenylenediamine dihydrochloride tablet (Sigma \# P7288), $2 \mathrm{ml}$ of PBS, $18 \mathrm{ml}$ of glycerol) were added. The comets were visualized using a Nikon Eclipse TS100 microscope with 63X objective and FITC (fluorescien isothiocyanate)-filter cube. Comet images were captured and analyzed using the LAI Automated Comet Assay Analysis System (Loats Associates, Inc. Westminster, MD). The tail moment [(\%DNA) (distance traveled)] was used for quantitative analysis of DNA damage for 80 comets per treatment/experiment. 


\subsection{Dihydroethidium Fluorescence}

Cells $\left(2.0 \times 10^{5}\right.$ cells $/ 35 \mathrm{~mm}^{2}$ dish $)$ were plated on sterile glass cover slips in fresh growth medium (DMEM/5\%FBS). Cells were left to attach for 12 hours and stimulated with NSC3852. All subsequent steps were performed in the dark. The redox - sensitive probe dihydroethidium was used to detect NSC3852 - stimulated superoxide generation. Cytosolic dihydroethidium exhibits blue fluorescence (excitation at $335 \mathrm{~nm}$, emission $420 \mathrm{~nm}$ ), but once it is oxidized by superoxide to ethidium, it emits a bright red nuclear fluorescence (excitation at 518, emission at 605). Dihydroethidium was dissolved in DMSO $(5 \mu \mathrm{M})$ ( D-11347, Molecular Probes, Eugene, OR) then added to cell culture medium for 15-30 minutes in incubator. Cell monolayer was washed three times with cold PBS. Cells were then fixed with $10 \%$ formaldehyde for 10 minutes at room temperature. Cells were washed with cold PBS and cover slips were mounted on slides using five drops of anti-fade solution (20mg p-phenylenediamine dihydrochloride tablet (Sigma \# P7288), 2ml of PBS, 18ml of glycerol). Cells were visualized using a Zeiss LSM 510 confocal microscope with 10x objective. Scale bars were generated and inserted by LSM software.

\subsection{Colorometric determination of reduced and oxidized glutathione}

The GSH and GSSG concentrations in MCF-7 cells were measured using an enzymatic method (GSH/GSSG-412 kit; OxisResearch, Portland, OR). Cells (3.0 x $10^{6}$ cells $/ 60 \mathrm{~mm}^{2}$ dish) were plated in $5 \mathrm{ml}$ DMEM/5\%FBS, left to attach for 12 hours. 
After the treatment, cells were washed with ice cold PBS, harvested, pelleted in a $15 \mathrm{ml}$ conical tubes by centrifugation (Sorvall GLC-2Bcentrifuge, Hoffman Estates, IL) for 5 minutes at $1200 \mathrm{rpm}$ and resuspended in $200 \mu \mathrm{l}$ of ice cold PBS. GSSG and GSH samples were prepared according to the directions from the suppliers. Briefly, samples were prepared in 5\% MPA (metaphosphoric acid (Sigma M-5043) with or without M2VP (1Methyl-2-vinyl-pyridium trifluoromethane sulfonate), GSH specific scavenger. Ellman's reagent (5'5-dithiobis-2-nitrobenzoic acid (DTNB)) was added to samples. DTNB reacts with GSH and form spectrophosphometrically detectable product at $412 \mathrm{~nm}$ (Spectra Max 340pc plate reader (Molecular Devices, Sunnyvale, CA)). GSSG was determined by reduction of GSSG to GSH mediated by glutathione reductase (GR), which was then determined by the reaction with Ellman's reagent.

\subsection{ESR (Electron Spin Resistance) measurements}

ESR spin trapping was used to detect production of short-lived free radical intermediates. This technique involves the addition-type reaction of a short-lived radical with a paramagnetic compound (spin trap) to form a relatively long-lived free radical product (spin adduct), which can then be studied using conventional ESR. The intensity of the signal is used to measure the amount of short-lived radicals trapped, and the hyperfine couplings of the spin adduct are generally characteristic of the original trapped radicals. The spin trapping is the method of choice for detection and identification of free radical generation due to its specificity and sensitivity. All ESR measurements were conducted using a Bruker EMX spectrometer (Bruker Instruments Inc. Billerica, MA 
01821, USA) and a flat cell assembly. Hyperfine couplings were measured (to $0.1 \mathrm{G}$ ) directly from magnetic field separation using potassium tetraperoxochromate $\left(\mathrm{K}_{3} \mathrm{CrO}_{8}\right)$ and 1,1-diphenyl-2-picrylhydrazyl (DPPH) as reference standards ( Janzen E. G., et al., 1968). The relative radical concentration was estimated by multiplying half of the peak height by $\left(\ddot{\mathrm{y}} \mathrm{H}_{\mathrm{pp}}\right)^{2}$, where $\ddot{\mathrm{y}} \mathrm{H}$ pp represents peak-to peak width. The Acquisit program was used for data acquisitions and analyses.

MCF-7 cells $\left(2.0 \times 10^{6}\right.$ cells $/ 60 \mathrm{~mm}^{2}$ dish $)$ were plated in $5 \mathrm{ml}$ DMEM/5\%FBS. After 48 hours cells were washed with HBSS, harvested and counted. Cells were pelleted in a $15 \mathrm{ml}$ conical tubes by centrifugation (Sorvall GLC-2Bcentrifuge, Hoffman Estates, IL) for 5 minutes at $1200 \mathrm{rpm}$, washed with $1 \mathrm{ml}$ ice cold PBS, centrifuged again and resuspended in ice cold PBS at $2 \times 10^{6}$ cells $/ \mathrm{ml}$. The radical production of the cells was then measured in the presence of the spin trap 5.5-dimethyl-1-pyrroline-N-oxide (DMPO, Aldrich Chemical, WI). Reactants (100 mM DMPO, PBS, cells +/- stimulant) were mixed in test tubes in a total volume of $1.0 \mathrm{ml}$ incubated at $37{ }^{\circ} \mathrm{C}$ and transferred to a flat cell for ESR measurements.

\subsection{Statistics}

The Sigma plot software (SpSS Inc., Chicago, IL), version 5.0 and Prism (GraphPad software, Inc., San Diego, CA), version 3.0. were used for statistical analysis. One way analysis of variance (ANOVA) was followed by the Dunnett's test for comparison of multiple groups with control. Statistically significant differences $(\mathrm{P}<0.05)$ were determined using Student's t-test. 


\section{RESULTS}

\section{Chapter 1. Screening of Quinoline ring - containing compounds}

Previous results in our laboratory have shown that quinidine, a quinoline ringcontaining drug, causes cell cycle arrest in $\mathrm{G}_{1}$ phase, cell cycle exit, inhibition of HDAC as well as stimulates cellular differentiation in MCF-7 breast tumor cells (Zhou, Q et al, 2000). We hypothesized that the quinoline aromatic ring systems contain a property that can induce antiproliferative changes in the cell and thereby lead to the restoration of a differentiated phenotype in breast cancer cells. Twenty three quinoline ring - containing compounds were obtained from NSC Compound Library or Sigma (Figure 6). The objective of the following set of experiments was to test whether other pharmacologically active quinolines possess the ability to arrest cell cycle, induce cellular differentiation with subsequent apoptosis and inhibit HDAC activity in breast tumor cell lines.

Results presented in Tables 1 and 2 are collaborative work of several members of our laboratory, and presented together to give the full picture of screening conducted. The results obtained by me are shown in bold. 


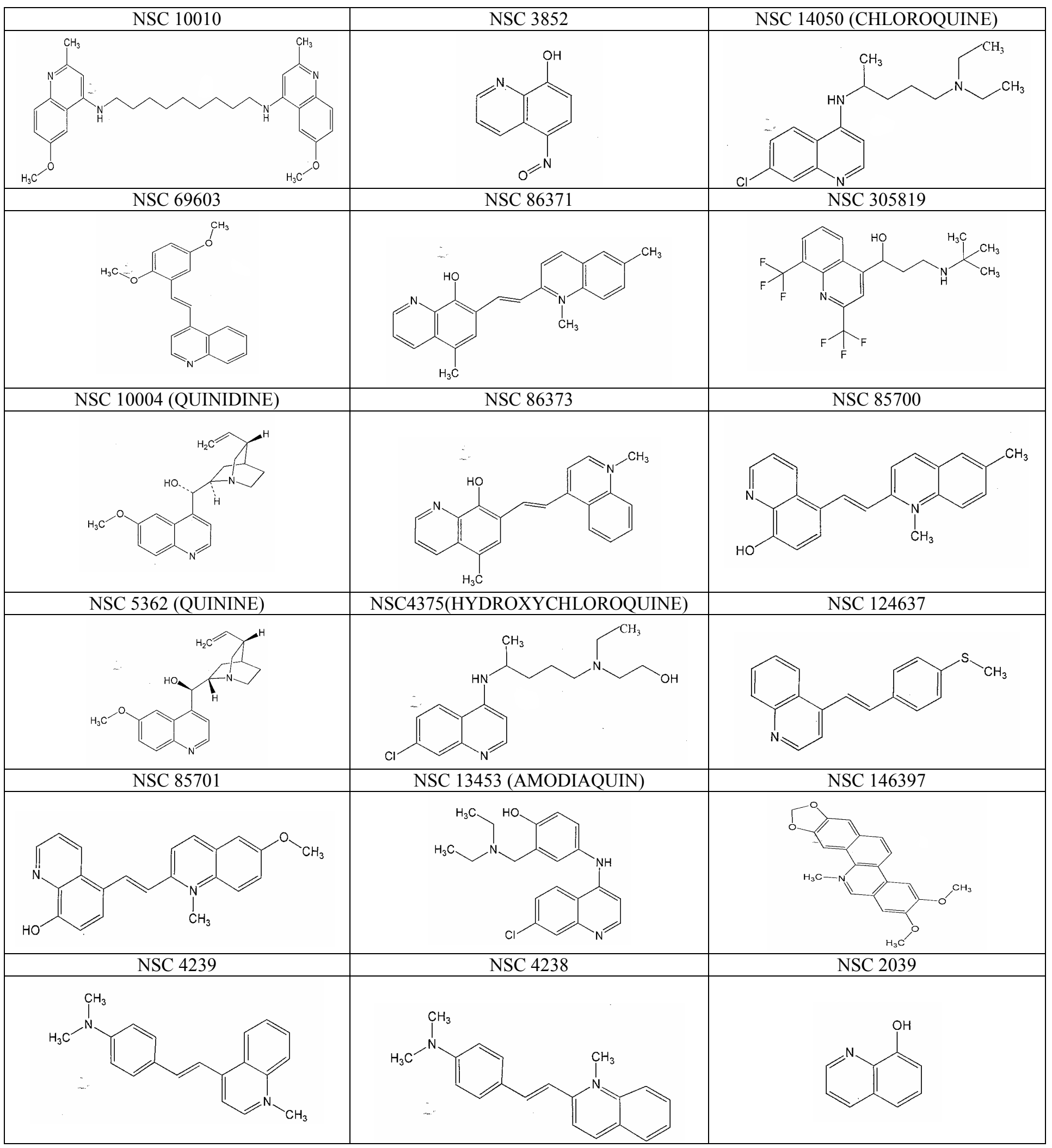




\begin{tabular}{|l|l|l|}
\hline $\mathrm{NSC} 149765$ (PRIMAQUINE) & QUINOLINE \\
\hline
\end{tabular}

Figure 6. Chemical structures of quinoline ring - containing compounds. 


\subsection{Survival of breast tumor cells treated with quinoline ring - containing compounds}

To determine $\mathrm{IC}_{50}$ values for antiproliferative activity of test compounds, the effect of NCI compounds on cell viability was measured. Cells were plated in 96 well dishes at the following densities: MCF-7 (4000), MDA-231 (500) and MCF-10A (4000). Tetrazolium dye mitochondrial metabolism (MTS) assays were performed as detailed in Materials and Methods and concentration / response analysis curves were built. Test NSC compounds caused a decrease in a survival of breast cancer cells (Table 1). Data in Table1 shows MTS metabolism $\mathrm{IC}_{50}$ determined for MCF-7 and MDA-MB-231 breast cancer cell lines under our experimental conditions and $\mathrm{GI}_{50}$ determined using sulforhodamine blue (SRB) staining reported by the NSC. MTS IC $_{50}$ values for MCF-10A normal human mammary epithelial cells were determined only for Chloroquine, NSC 3852, 10010, 69603, 86371 and 305819 , because these compounds showed statistically significant differentiation activity, determined by Ki-67 immunohistochemical assay (see section 1.2.). 
Table 1. MTS IC50 values and GI50 values obtained from NCI database.

MCF-7, MDA-MB-231 and MCF-10A cells were plated at density $4.0 \times 10^{3}, 5.0 \times 10^{2}$ and $4.0 \times 10^{3}$ cells per well in 96-well plates, respectively, in $225 \mu$ of $5 \%$ FBS DMEM or MEGM (MCF-10A). The cells were grown for 12 hours. The NCI compounds were added at ten different concentrations into each well of the plate and incubated for 48 hours. Cell growth was measured using a MTS assay kit. Data are the mean of $n=2$ or 3 independent experiments performed in triplicate. The concentration of each agent that inhibited cell growth by $50 \%\left(\mathrm{IC}_{50}\right)$ was determined in each case using nonlinear regression analysis to fit inhibition data to the dose-response curve. $\mathrm{GI}_{50}$ is a growth inhibition index reported by the NCI. 


\section{Table 1}

\begin{tabular}{|c|l|c|c|c|c|c|}
\hline & & \multicolumn{2}{|c|}{ MCF-7 } & \multicolumn{2}{c|}{ MDA-231 } & MCF-10A \\
\hline NSC \# & Name & $\begin{array}{c}\text { MTS IC50 } \\
\text { (uM) }\end{array}$ & $\begin{array}{c}\text { SRB GI50 } \\
\text { (uM) }\end{array}$ & $\begin{array}{c}\text { MTS IC50 } \\
\text { (uM) }\end{array}$ & $\begin{array}{c}\text { SRB GI50 } \\
\text { (uM) }\end{array}$ & $\begin{array}{c}\text { MTS IC50 } \\
\text { (uM) }\end{array}$ \\
\hline 14050 & Chloroquine & 33 & 19 & 10.8 & 16 & $>\mathbf{1 0 0}$ \\
\hline 4375 & Hydroxychloroquine & 57 & $n d$ & 56.6 & $n d$ & \\
\hline 13453 & Amodiaquine & 7 & $n d$ & 6 & $n d$ & \\
\hline 10004 & & 113 & $n d$ & & & \\
\hline 5362 & Quinine & 40 & 60 & 173 & 100 & \\
\hline 157387 & Mefloquine & 3 & $n d$ & & & \\
\hline 305789 & Halofantrine & 11 & 10 & 20.7 & 20.5 & \\
\hline 149765 & Primaquine & $\mathbf{3}$ & 16 & $>100$ & 43.7 & \\
\hline & Quinoline & 62 & $n d$ & $n d$ & $n d$ & \\
\hline 2039 & & $\mathbf{8}$ & 2 & $\mathbf{7 . 5}$ & 3 & \\
\hline 3852 & & $\mathbf{1 0}$ & 2 & $\mathbf{2}$ & 6.4 & $\mathbf{9 . 5}$ \\
\hline & Quinolinic Acid & 28 & $n d$ & 1.4 & $n d$ & \\
\hline 69603 & & 14 & 0.9 & 0.9 & 0.6 & $\mathbf{2 . 6}$ \\
\hline 305819 & & 7 & 13 & 3.9 & 9.4 & $\mathbf{5 5 . 6}$ \\
\hline 124637 & & 13 & 14 & 34.4 & 17 & \\
\hline 4239 & & $\mathbf{0 . 7}$ & 2 & $\mathbf{1}$ & 6 & \\
\hline 10010 & & $\mathbf{4}$ & 5.4 & $\mathbf{1}$ & 1.3 & $\mathbf{3 . 2}$ \\
\hline 86371 & & 6 & $n d$ & 1.1 & $n d$ & $\mathbf{2 8 . 2}$ \\
\hline 86373 & & 13 & $n d$ & 12.9 & $n d$ & \\
\hline 86372 & & $\mathbf{0 . 2}$ & 0.1 & $\mathbf{0 . 1}$ & 0.2 & \\
\hline 85700 & & 7 & 7 & $n d$ & 33.2 & \\
\hline 85701 & & $\mathbf{4}$ & 4 & $\mathbf{0 . 6}$ & $n d$ & \\
\hline 4238 & & $\mathbf{0 . 4}$ & 2 & $\mathbf{0 . 7}$ & 0.9 & \\
\hline
\end{tabular}




\subsection{Accumulation of cytoplasmic lipid droplets in MCF-7 cells caused by NSC compounds}

To determine whether growth inhibition by NSC compounds was associated with cell differentiation we assessed cytoplasmic lipid droplets accumulation defined by Oil Red O. Based on the knowledge that lipid droplets are found in the cytoplasm of normal epithelium (Jing, Y. et al, 1996), and the induction of differentiation in human breast cancer cells by heregulin (Xiao-Feng Le et al, 2000) and retinoic acid (Bacus. S et al, 1990) is accompanied by the accumulation of cytoplasmic lipid droplets, we decided to use lipid droplet accumulation as a marker of differentiation.

The MCF-7 or MDA-MB-231 cells were plated at a density of $2 \times 10^{5} / 35 \mathrm{~mm}^{2}$ dish in $3 \mathrm{ml}$ of DMEM/5\%FBS medium. After forty eight hour treatment cells were fixed and the Oil Red O staining of the cells was performed. As shown in Figure 7, drug treated cells displayed well defined accumulation of cytoplasmic lipid droplets compared to control, where no accumulation of lipid droplets was observed. The range between the concentrations needed to induce lipid droplets formation is between $0.1 \mathrm{X}$ the $\mathrm{MTS}_{\mathrm{IC} 50}$ to $2 \mathrm{X} \mathrm{MTS}_{\mathrm{IC} 50}$ (Table 2). Lipid droplet formation is observed during cellular differentiation, thus we concluded that quinoline ring - containing compounds induce cellular differentiation in MCF-7 and MDA-231 breast cancer cell lines. 


\section{MCF-7}

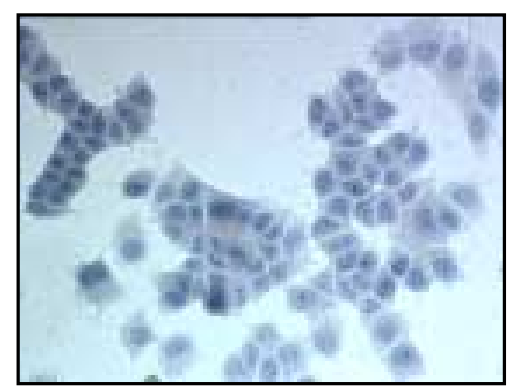

Solvent

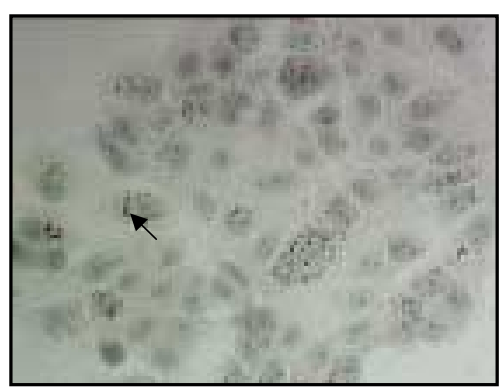

NSC 3852

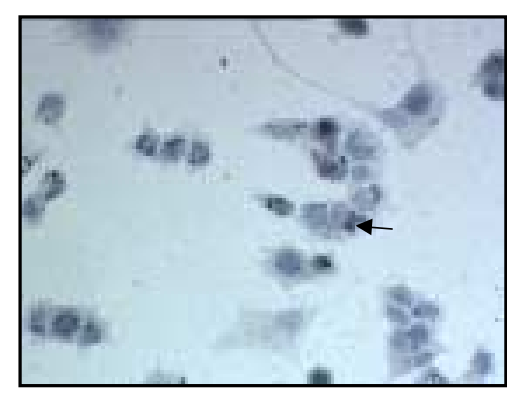

NSC10010

Figure 7. Visualization of cellular differentiation in MCF-7 cells using Oil Red O Histochemistry: $2 \times 10^{5}$ MCF-7 cells were plated in DMEM / 5\% FBS cultured medium. Cells were grown for 12 hours and then treated with NSC $3852(10.0 \mu \mathrm{M})$ and NSC $10010(4.0 \mu \mathrm{M})$ for 48 hours. Forty eight hours later cells were fixed and the Oil Red O staining of the cells was performed. Cells were counter-stained with Mayer's hematoxylin to visualize the cytoplasmic lipid droplets (red color) and the cell nuclei (blue color). Arrows indicate lipid droplets in cytoplasm. 


\subsection{Effect of NSC compounds on Ki67 antigen in MCF-7 cells}

Ki-67 is a nuclear antigen present exclusively in cycling cells (Gerdes et al. 1983). Ki-67 antigen is thus used as a marker of cell proliferation, as it can not be detected in non-proliferating cells.

MCF-7 cells were treated with NSC compounds at $\mathrm{IC}_{50}$ values for $48 \mathrm{hr}$. Ki-67 immunohistochemical assay was performed as described in Materials and Methods. Figure 8 represents control and drug treated MCF-7 cells after immunohistochemical staining of Ki-67 antigen (brown color) and counter-staining with Mayer's hematoxylin (blue color). Brown cells are Ki-67 positive and represent cells in $\mathrm{G}_{1}, \mathrm{~S}, \mathrm{G}_{2}$ and $\mathrm{M}$ phases of cell cycle. Blue cells are $\mathrm{Ki}-67$ negative and represent the population of nonproliferating $\left(\mathrm{G}_{0}\right)$ cells. Ki-67 index in MCF-7 cells was calculated (Table 2). Ki-67 index equals \% Ki-67 negative cells in drug-treated / \% Ki-67 negative cells in control cells. The Ki-67 index in the control cells equals one. The larger the Ki-67 index, the greater the proportion of $\mathrm{G}_{0}$ cells in the population. Our results indicate that NSC10010, NSC3852, Chloroquine, NSC86371, NSC69603, NSC305819 compounds were able to shift significantly proliferating MCF-7 cells into $\mathrm{G}_{0}$ phase after 48 hours of treatment. 


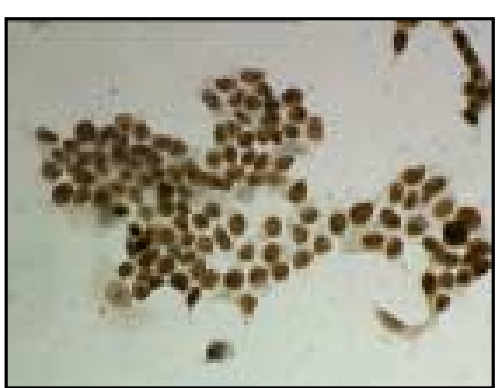

Solvent



NSC 3852

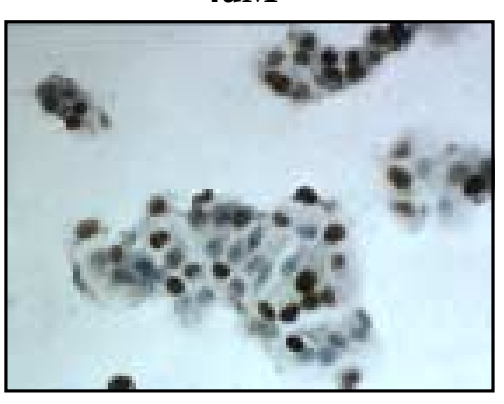

NSC 10010

Figure 8. Ki-67 immunohistochemistry staining: $2 \times 10^{5}$ MCF-7 cells were plated in DMEM / 5\% FBS culture medium. Cells were grown for 12 hours on the glass cover slips and then treated with NSC $3852(10.0 \mu \mathrm{M})$ and NSC $10010(4.0 \mu \mathrm{M})$. Forty eight hours later cells were assayed for Ki-67 immunoreactivity. A minimum of 500 cells were counted per slide. Brown staining indicates Ki-67 positive or cycling cells. Blue staining indicates Ki-67 negative or $\mathrm{G}_{0}$ cells. 


\subsection{Inhibition of HDAC enzymatic activity}

Histone deacetylases are responsible for the hydrolytic removal of acetyl groups from specific histone lysine residues, acetylation of which is catalyzed by histone acetyltransferases (M. Grunstein, 1997). Histone deacetylase inhibitors have shown promise as anti-tumor agents (David M. Vigushin and R. Charles Coombers, 2002). This has stimulated interest in the screening of compounds for HDAC inhibition (Gloria $\mathrm{H}$. Su et al, 2000).

We used a histone deacetylase in vitro assay to screen compounds for direct HDAC inhibition activity. All the quinoline compounds were tested at their MTS $\mathrm{IC}_{50}$ levels. HeLa cells containing predominantly HDAC1 and HDAC2 were used as the HDAC source. Data in Table 1 shows that only NSC86371 and NSC3852 directly inhibited HDAC. All other quinoline ring - containing compounds, that induced a more differentiated phenotype in MCF-7 human breast cancer cells failed to inhibit HDAC activity. Thus, we concluded that HDAC inhibition is not required for the differentiation response in MCF-7 cell treated by quinolines.

All following experiments were conducted on NSC10010, NSC3852, Chloroquine, NSC86371, NSC69603 and NSC305819 based on the fact that these compounds showed significant differentiation activity in Ki67 assay. 


\section{Table 2}

Oil Red O: 2 x 10 $10^{5}$ MCF-7 or MDA-231 cells were plated in DMEM / 5\% FBS cultured medium. Cells were grown for 12 hours and then treated with serial dilutions of each compound for $48 \mathrm{hr}$. Cells were fixed and stained with Oil Red O. Data represent the lowest concentrations of each NSC compound that causes lipid droplet formation in human breast cancer cell lines.

Ki-67 assay: MCF-7 cells were grown for 12 hours and then treated with MTS $\mathrm{IC}_{50}$ values of each compound for 48 hours. Immunohistochemistry of Ki-67 was performed. Cells were visualized by light microscopy and individually assigned to Ki-67 positive and Ki-67 negative groups. A minimum of 500 cells was counted per cover slip. The Ki-67 index equals \% Ki-67 negative cells with drug treatment / \% Ki67 negative cells in control. The data are mean +/- SEM of three experiments.

HDAC activity: Direct inhibition of HDAC activity by test compounds was measured using HDAC Fluorescence Activity Assay. MTS $\mathrm{IC}_{50}$ levels of each compound were used.

* indicates significantly different from the control values $(\mathrm{p}<0.05)$. 


\section{Table 2}

\begin{tabular}{|c|c|c|c|c|c|c|}
\hline \multicolumn{7}{|c|}{ Differentiation Activity } \\
\hline & & & MCF-7 & MDA-231 & MCF-7 & \\
\hline$\#$ & NSC \# & Name & $\begin{array}{c}\text { Oil Red } \\
\text { O } \\
\text { (uM) }\end{array}$ & $\begin{array}{l}\text { Oil Red O } \\
\text { (uM) }\end{array}$ & Ki67 Index & $\begin{array}{c}\text { HDAC } \\
\text { activity } \\
(\% \\
\text { control) }\end{array}$ \\
\hline 1 & 14050 & Chloroquine & 1 & & $6.6^{*}$ & $91 \pm 1$ \\
\hline 2 & 4375 & Hydroxychloroquine & 5 & & 3.6 & \\
\hline 3 & 13453 & Amodiaquine & 10 & & 2.4 & $86 \pm 4$ \\
\hline 4 & 10004 & & 10 & & 5 & $100 \pm 13$ \\
\hline 5 & 5362 & Quinine & 30 & & 4.1 & $102 \pm 14$ \\
\hline 6 & 157387 & Mefloquine & Negative & & 0.3 & $90 \pm 2$ \\
\hline 7 & 305789 & Halofantrine & 5 & & 1.4 & $81 \pm 13$ \\
\hline 8 & 149765 & Primaquine & 2.5 & 27 & 1.1 & $95 \pm 14$ \\
\hline 9 & & Quinoline & Negative & & 0.4 & $96 \pm 7$ \\
\hline 10 & 2039 & & 15 & 15 & 1.6 & $95 \pm 4$ \\
\hline 11 & 3852 & & 10 & 8 & 7.2 * & $69 \pm 6$ * \\
\hline 12 & & Quinolinic Acid & Negative & & 0.4 & $99 \pm 6$ \\
\hline 13 & 69603 & & 1 & & 6 * & $111 \pm 7$ \\
\hline 14 & 305819 & & 1 & & $5.8^{*}$ & $90 \pm 17$ \\
\hline 15 & 124637 & & & & 3.4 & $127 \pm 14$ \\
\hline 16 & 4239 & & 1.3 & 0.8 & 1.9 & $96 \pm 4$ \\
\hline 17 & 10010 & & 3.5 & 2 & $8.3^{\star}$ & $94 \pm 8$ \\
\hline 18 & 86371 & & 1 & & 6 * & $65 \pm 5^{*}$ \\
\hline 19 & 86373 & & 1 & & 4.7 & $97 \pm 2$ \\
\hline 20 & 86372 & & 2 & 5 & 0.8 & $91 \pm 7$ \\
\hline 21 & 85700 & & 1 & & 4.1 & $97 \pm 1$ \\
\hline 22 & 85701 & & 0.5 & & 2.7 & $90 \pm 7$ \\
\hline 23 & 4238 & & 0.7 & 1 & 1.9 & $109 \pm 13$ \\
\hline
\end{tabular}




\subsection{NSC compounds cause growth suppression in MCF-7 breast cancer cells}

Experiments were performed to assess the effects of NSC3852, 10010, 69603, 86371, 305819 and Chloroquine on MCF-7 cell growth.

MCF-7 cells MTS IC $_{50}$ values of test compounds were used in this experiment. Cell numbers were reduced by all test compounds (Figure 9). NSC10010 was the most toxic compound; no surviving cells were detected in the dish after 72 hours of treatment. NSC69603 had cytostatic effect on the cells. The data also demonstrate that only for NSC305819 MTS $\mathrm{IC}_{50}$ concentration caused 50\% decrease in cell number. This observation suggests that growth inhibition is more sensitive indicator of toxicity than MTS. 
Figure 9. Growth suppression induced by NSC compounds:MCF-7 cells were plated at the density $1.5 \times 10^{5}$ per $35 \mathrm{~mm}$ dish. Cells were left to attach for 12 hours and MCF-7 cells MTS $\mathrm{IC}_{50}$ values of test compounds were added. Cells were harvested and counted using hemocytometer at the times indicated. Data represent the mean \pm S.M.E. range of 3 experiments. Arrow indicates the beginning of the treatment. 

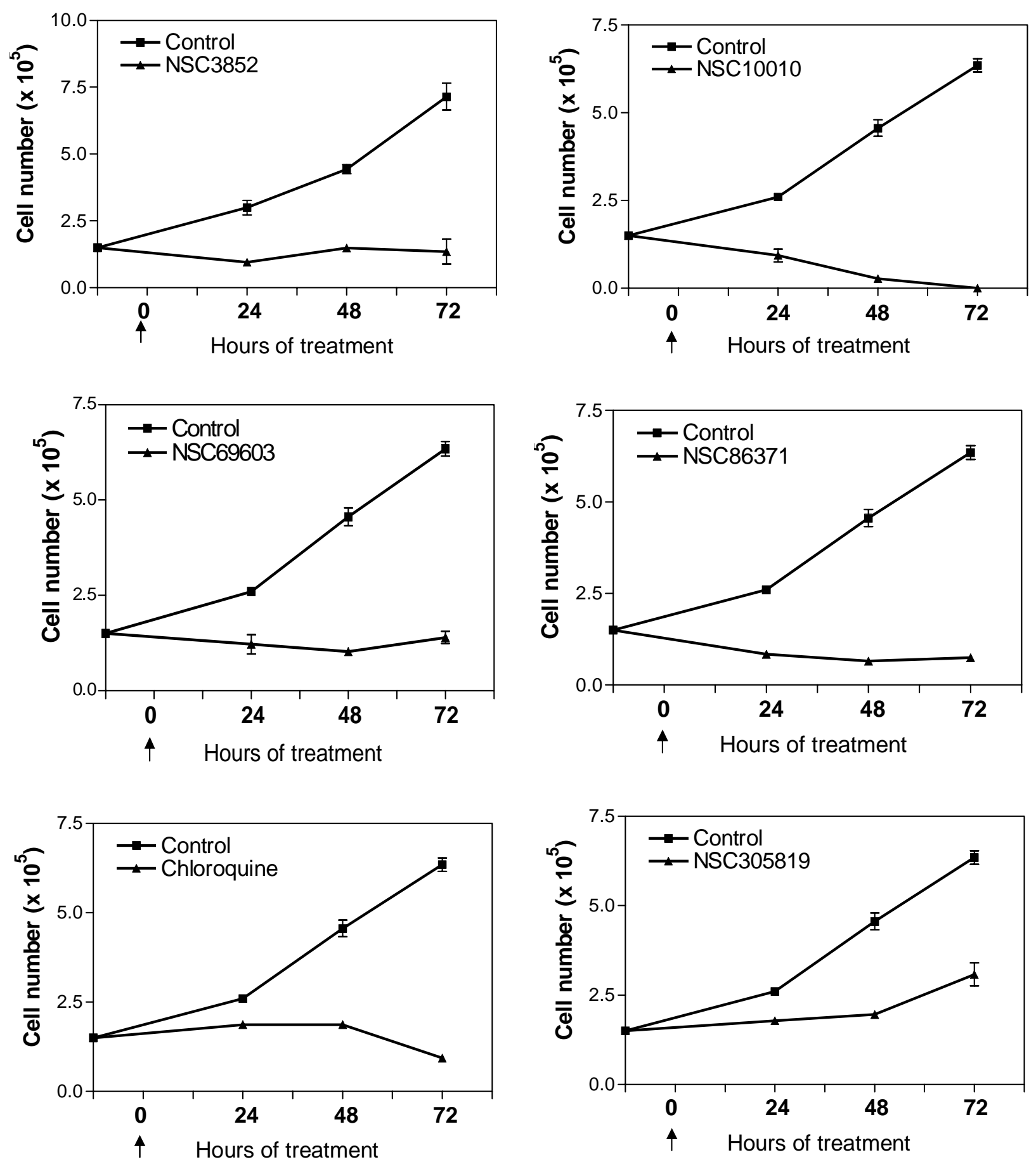


\subsection{Quinoline ring - containing compounds induce apoptosis in MCF-7 and MCF- $10 \mathrm{~A}$ cells}

There are two distinct forms of eukaryotic cell death: necrosis and apoptosis. Apoptosis is the most common form of eukaryotic cell death (Katja C. Zimmermann and Douglas R. Green, 2001). Inappropriate regulation of apoptosis plays an important role in pathological conditions such as cancer (Gerard I. Evan and Karen H. Vousden, 2001). During apoptosis the endogenous endonuclease cleaves double stranded DNA at the most accessible internucleosomal linker regions, generating mono- and oligonucleosomes. Due to the fact that DNA degradation occurs several hours before plasma membrane breakdown, there is the specific stage of apoptosis that is characterized by the enrichment of mono- and -oligonucleasomes in the cytoplasm of the apoptotic cells (Terui, Y. et al, 1995).

We used the cell death ELISA, based on a quantitative sandwich - enzyme immunoassay - principle to detect apoptosis in response to quinolines as described in Materials and Methods. Mouse monoclonal antibodies directed against DNA and histones, respectively allowed specific determination of mono- and oligonucleosomes in the cytoplasmic fraction of cell lysates. Apoptosis measured as a nucleosome release is reported here as the ratio of treated/control values. Nucleosome release values of the control cells equal one. As shown in Figure 10, after 24 hours of treatment no nucleosome release was detected in treated cells. After 48 hours cell treated with NSC3852, NSC86371 and Chloroquine exhibit 4 times increase in nucleosome release values compared to control. After 72 hours of treatment NSC3852, NSC305819, 
NSC86371 and Chloroquine exhibit 2.2, 2.7, 3.5 and 7.5 nucleosome release values respectively.

No nucleosome release was detected in cells treated with NSC69603 and NSC10010. Visual inspection of the dishes prior to the nucleosome assay showed that cells treated with NSC10010 looked smaller, were not well attached and relative number of the cells decreased compared to control cells. The nucleosome ELISA data for NSC10010 can be explained by the fact, that stage of apoptosis that is characterized by the enrichment of mono- and-oligonucleasomes in the cytoplasm of the apoptotic cells is quite short and this stage of apoptosis might already be passed in the cells treated with more toxic compounds by 24 hour time point. MCF-10A cells exposed to NSC69603 for 72 hours exhibit the highest $(\sim 5.5)$ nucleosome release values. The absence of the bar for NSC10010 is explained by the absence of any survived cells after 48 hours of treatment (Figure 10). NSC3852 had lower nucleosome release in MCF-10A than in MCF-7 cells. Chloroquine did not cause any apoptosis in MCF-10A cells. NSC86371 and NSC305819 induced less apoptosis in MCF-10A cells compared to MCF-7 cells. 
Figure 10. Induction of apoptosis by NSC compounds: MCF-7 cell and MCF-10A cells (4000 per well) were plated in 96-well plates. Twelve hours later test compounds were added. In MCF-7 cells 24, 48 or 72 hours later and in MCF-10A cells 72 hours later apoptosis was assayed using a nucleosome release ELISA. Apoptosis measured as a nucleosome release is reported here as the ratio of treated/control values obtained in a single experiment performed in triplicate. Statistically significant differences are indicated $(* \mathrm{P}<0.05)$. 


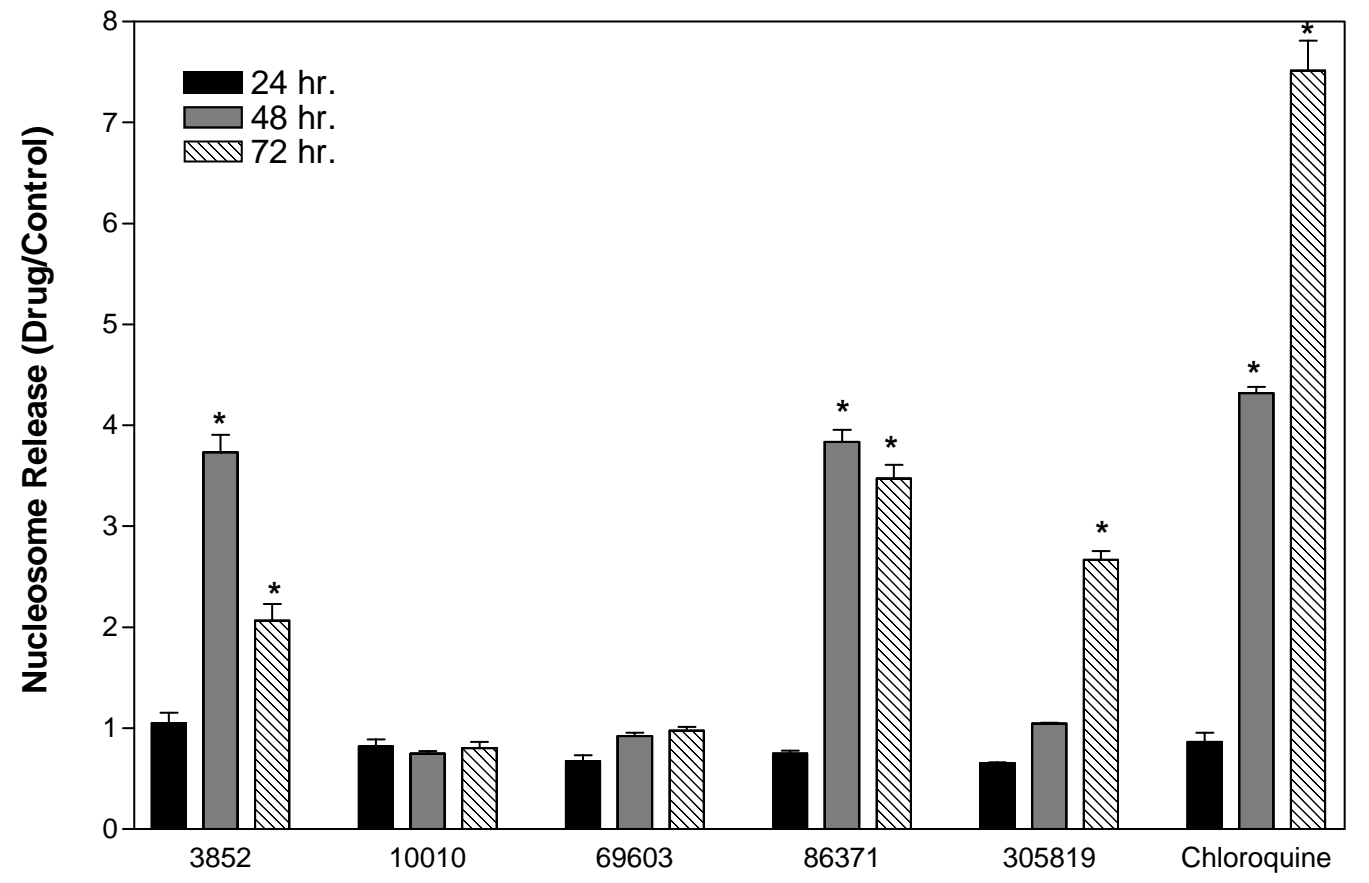

MCF10A (72hr)

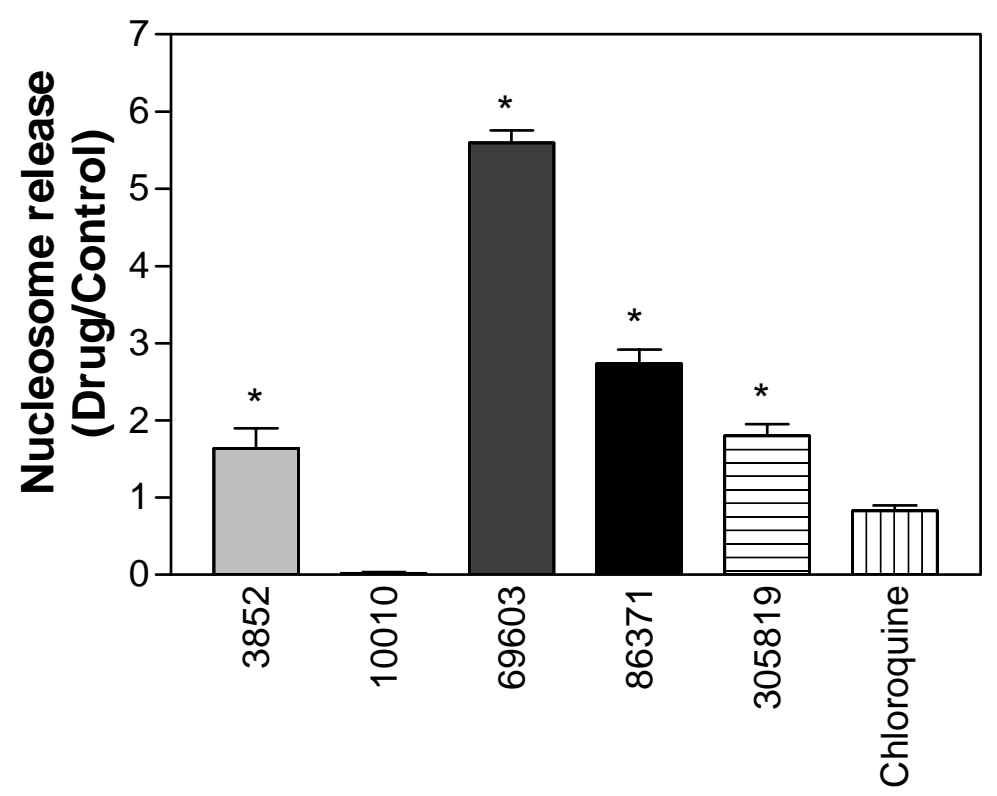




\subsection{DNA damage induced by quinoline ring compounds}

Single gel electrophoresis assay (Comet assay) was used as an index of cytotoxic effect of test compounds on MCF-7 cells. This method specifically evaluates DNA damage in cells. The principle of the assay is based upon the ability of DNA fragments to migrate out of the cells under the influence of an electric field. When a current is applied undamaged DNA migrates slower, than DNA fragments (R. R. Tice et al, 2000).

Comet assay was performed to quantify DNA damage in MCF-7 and MCF-10A cells. The greater the DNA damage, the longer the comet tail as quantified by tail moment (Figure 11A), which measures the amount of damaged DNA in the tail and the electrophoretic distance traveled. Figure 11A shows that there is significant DNA damage after 24 hours of treatment with NSC3852 compared to control. No statistically significant damage to DNA by other compounds tested was detected. By 24 hours, few cells were found in the dish treated with NSC10010, but DNA of those survived cells was not damaged. Interestingly, no DNA damage was detected in MCF-10A normal human mammary epithelial cells after 24 hour treatment with quinoline ring - containing compounds, with the exception of NSC86371, where very little DNA damage occurred (Figure 11C).

The data presented above suggest that NSC3852 selectively induced DNA damage in MCF-7 breast cancer cells, but not in MCF-10A normal epithelial cells. Thus, NSC 3852 not only caused a significant shift of cells into $\mathrm{G}_{0}$ phase of cell cycle it also selectively induced DNA damage in MCF-7 breast cancer cells. 


\section{Figure 11. DNA damage induced by quinolines}

A. The example of three different samples of DNA with tail moment 0,5 and 75 visualized by epifluorescence microscope. Cells were immobilized in a bed of low melting point agarose, gently lysed and treated with alkali to unwind, denature the DNA and hydrolyze sites of damage, following electrophoresis and staining of samples with a fluorescent DNA intercalating dye. The distribution of DNA between the tail and the head of the comet was used to evaluate the degree of DNA damage. Tail Moment $=[(\%$ DNA $)($ distance $)]$

B. and C. MCF-7 and MCF-10A cells $\left(1 \times 10^{5} / 35 \mathrm{~mm}^{2}\right.$ dish $)$ were treated with MTS $\mathrm{IC}_{50}$ levels of the quinoline ring compounds for 24 hours. The number of comets with tail moments ranging between $0-2,5-10,10-20,20-50,50-100$ and $>100$ are plotted for each treatment group. Eighty cells were analyzed per experiment. Data shown are pooled results of the three independent experiments in each cell line. Statistically significant differences are indicated $(* \mathrm{P}<0.05)$. 
Figure11 A. Tail moments

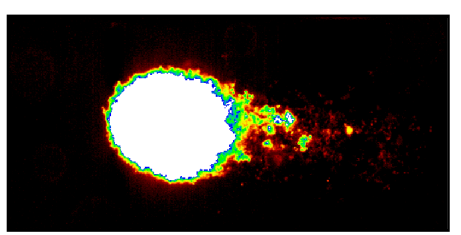

0

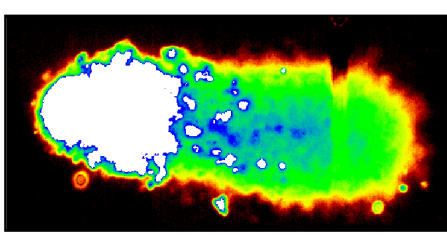

5

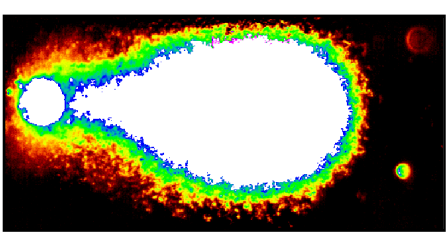

75

Figure 11B. Comet assay

MCF-7(24hr)

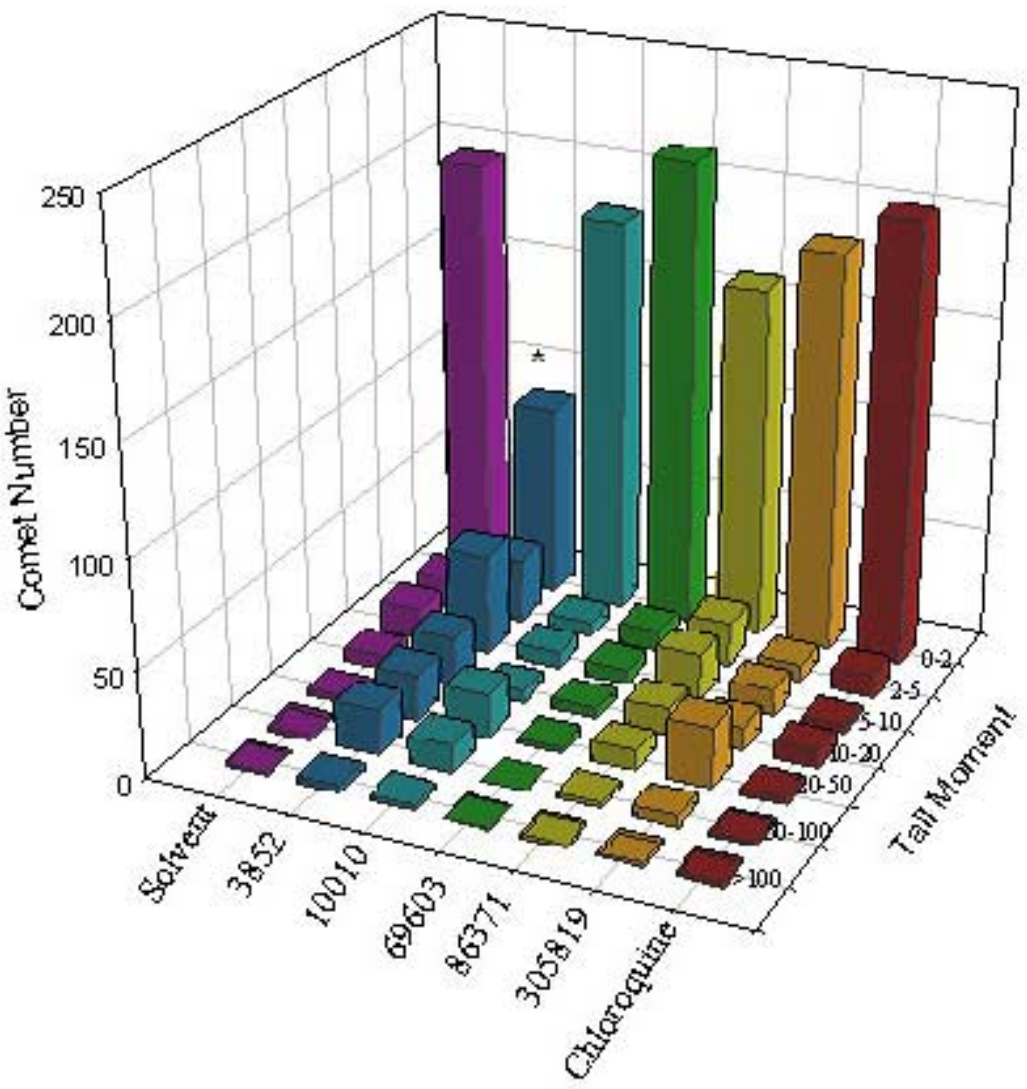


Figure 11C. Comet assay

MCF-10A (24hr)

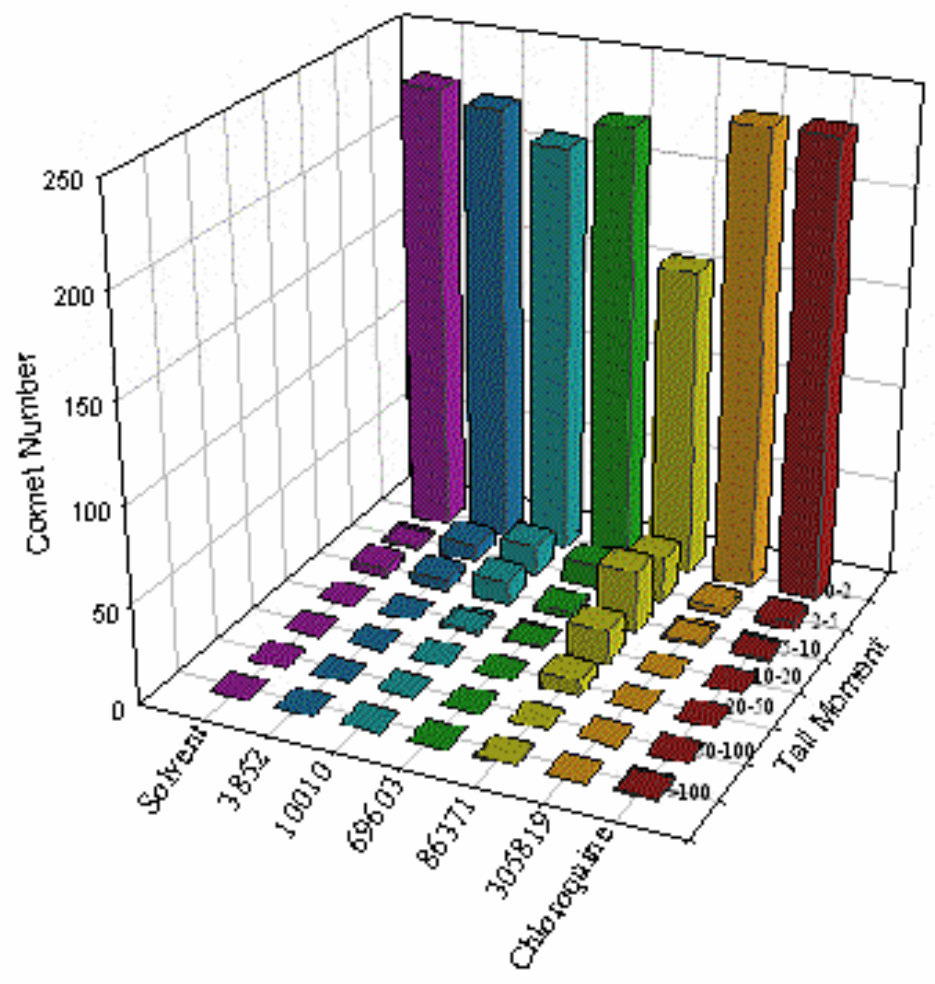




\subsection{NSC compounds cause growth suppression in MCF-10A normal mammary epithelial cells}

Very little DNA damage was detected in MCF-10A normal mammary epithelial cells in response to treatment with NSC compounds. The next experiment was conducted to evaluate the relative toxicity of these compounds in the MCF- 7 breast cancer cell line compared with MCF-10A normal human mammary epithelial cells. Therefore, we tested whether the MCF-10A cell growth is inhibited at concentrations of compounds = MTS $\mathrm{IC}_{50}$ in MCF-7 cells.

Short-term growth experiment showed that MCF-10A cell numbers were significantly reduced by all of the test NSC compounds (Figure 12). Control MCF-10A cells increased 4 fold by 48 hours. NSC 305819 and Chloroquine inhibited increase in cell number. MCF-10A IC 50 values for these compounds were higher than MCF-7 IC $_{50}$ values (Table 1), implying that these compounds are less toxic to MCF-10A compared to MCF-7. NSC86371, 3852, 69603, 10010 reduced cell numbers below plating density. Compound NSC10010 was clearly toxic to the cells after 48 hour treatment, which explains absence of the bar for NSC10010. 


\section{MCF-10A}

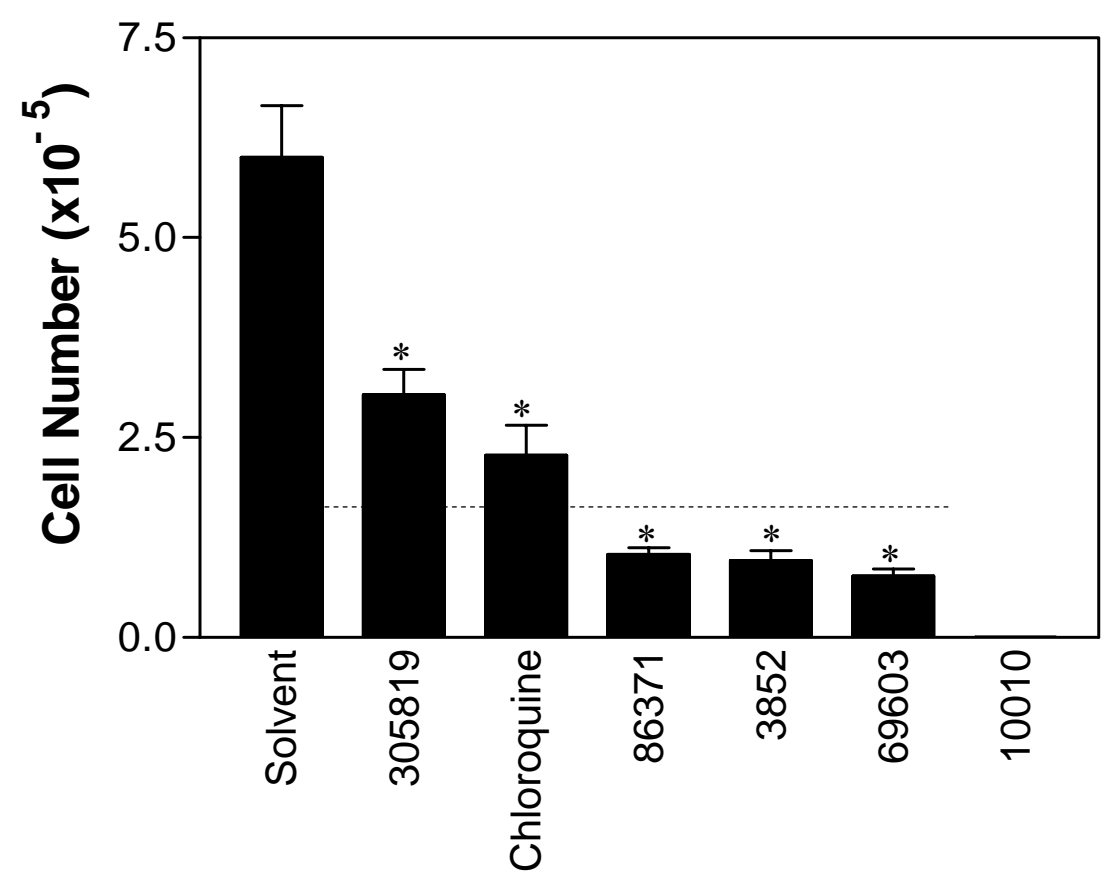

Figure 12. MCF-10A cell growth: MCF-10A cells were plated at a density $2 \times 10^{5}$ per $35 \mathrm{~mm}^{2}$ dish. Cells were left to attach for 12 hours, then MCF-7 cells IC $_{50}$ values of NSC compounds were added. Forty eight hours later cells were harvested and counted. Data represent the mean \pm S.E.M. range of 3 experiments. The dashed line indicates the initial number of cells plated at time zero. 


\subsection{Significant findings and future directions}

Twenty three quinoline ring-containing compounds were obtained from the NSC Compound Library or Sigma. Test compounds examined in MTS assay were antiproliferative in MCF-7 and MDA-231 breast cancer cell lines. $\mathrm{IC}_{50}$ values for antiproliferative activity of test compounds were determined.

Next, we determined whether those antiproliferatives could induce cell differentiation. Differentiation activity was measured by accumulation of lipid droplets and the increase in Ki-67 index. The lowest concentration of compound that induced the appearance of lipid droplets in MCF-7 and MDA-231 cell lines was determined and compared to MTS determined $\mathrm{IC}_{50}$ values. The range between those concentrations was between $0.1 \mathrm{X} \mathrm{MTS} \mathrm{IC5}_{0}$ to $2 \mathrm{X} \mathrm{MTS}_{\mathrm{IC} 50}$. All subsequent experiments were performed at a single concentration, the $\mathrm{MTS}_{\mathrm{IC} 50}$. Ki-67 assay was performed, because it is more definitive indicator of differentiation activity than Oil Red O assay. Ki-67 assay data indicate that among all test compounds NSC10010, NSC3852, Chloroquine, NSC86371, NSC69603, NSC305819 were able to significantly enrich the population of MCF-7 cells in $\mathrm{G}_{0}$ phase after 48 hours of treatment.

Next, test compounds were screened in a cell-free assay for HDAC inhibitory activity. Only NSC3852 and NSC 86371 significantly inhibited HDAC activity. Only differentiation inducing quinolines (NSC10010, NSC3852, Chloroquine, NSC86371, NSC69603, and NSC305819) were chosen for further screening. 
Cell growth experiments showed that NSC10010 was the most toxic in MCF-7 and MCF-10A cells. Interestingly, DNA damage was not detected in live MCF-7 or MCF$10 \mathrm{~A}$ cells after 24 hours of treatment.

Chloroquine had cytostatic effect on MCF-7 cell growth by 48 hours, but by 72 hours cell number went down, which correlates with finding that Chloroquine induced apoptosis by 48 hours $\sim 4.5$ fold and by 72 hours $\sim 7.5$ fold. The delayed apoptosis effect can explain the absence of DNA damage measured by Comet assay after 24 hours of treatment. No DNA damage was detected in Chloroquine treated MCF-10A cells after 24 hours; Chloroquine exhibited cytostatic effect of MCF-10A after 48 hours of treatment.

NSC69603 suppressed MCF-7 cell growth at all time points. It did not cause either apoptosis or DNA damage in MCF-7 cells by 24 hours. Apoptosis was not detected in MCF-7 cells even by 72 hours, but it was significant in MCF-10A cells at that time point, which might explain the cytotoxic effect NSC69603 had on MCF-10A cells after 48 hours of treatment. Comet assay preformed on MCF-10A cells did not show any DNA damage after 24 hours of treatment.

NSC86371 had cytotoxic effect on MCF-7 by 24 hours. Induction of apoptosis in MCF-7 cells by NSC86371 was significant and delayed (48 hours), subsequently no DNA damage was detected in MCF-7 cells treated with NSC86371 for 24 hours. NSC86371 induced apoptosis (72 hours), slightly induced DNA damage (24 hours), and had cytotoxic effect (48 hours) on MCF-10A cells.

NSC305819 was the only compound that had cytostatic effect on MCF-7 cells. It significantly induced apoptosis in MCF-7 cells by 72 hours, thus no DNA damage was detected in these cells by 24 hours. NSC305819 had cytostatic effect on MCF-10 cell at 
48 hour time point. It induced apoptosis by 48 hours in MCF-10A cells, and did not cause DNA damage in MCF-10A cells by 24 hours.

NSC3852 had cytostatic effects on MCF-7 cells in growth experiments. NSC3852 significantly induced apoptosis in MCF-7 by 48 hours, and NSC3852 selectively induced DNA damage in MCF-7 cells by 24 hours (did not in MCF-10A cells). NSC3852 induced apoptosis and had cytotoxic effect on MCF-10 cells by 48 hours.

Based on the reasons presented below NSC3852 has been chosen as a "lead" compound for further investigation.

NSC3852 inhibited cell growth and induced differentiation (Ki-67 index) in MCF-7 cells. It was one of the two NSC compounds that significantly inhibited HDAC activity. NSC3852 selectively induced DNA damage in MCF-7 cells by 24 hours (did not in MCF-10A cells), and significantly induced apoptosis in MCF-7 by 48 hours. In the rapid in vitro assay for transcellular permeation of drug through artificial lipid membrane (PAMPA) NSC3852 was predicted to be active after oral administration (Martirosyan A. R. et al., 2004). Furthermore, NSC3852 meets the Lipinski rule of five (a common set of physicochemical properties frequently exhibited by drugs): a molecular weight $\leq 500,<5$ hydrogen-bond donors, $<10$ hydrogen-bond acceptors, and an oil-water partition (log P) between -1 and +5 (Lipinski C. A. et al., 1997). 


\section{Chapter 2. NSC3852 modulate Rb/E2F-1/Myc pathway}

The following experimental setting was used for all experiments discussed in Chapter 2. MCF-7 cells were grown in T-75 tissue culture flask until $95-100 \%$ confluency. At this point the cells are largely $(\sim 80 \%)$ in $\mathrm{G}_{0} / \mathrm{G}_{1}$ phase (Wang L., et al., 1998). This cell population was harvested and replated in tissue culture dish in DMEM/5\% FBS medium. Cells were left to attach for 12 hours, then solvent $(0.001 \%$ DMSO) or $10 \mu \mathrm{M}$ NSC3852 was added to the dishes. Cells were harvested in protein harvesting buffer after the treatment.

Figure 13 shows temporal relationship between cell plating time, treatment time and the MCF-7 cell cycle phase. All the data points discussed in the text refer to the hours of treatment. 
Hours after plating

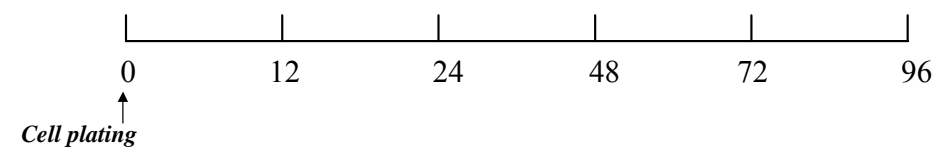

Hours of treatment

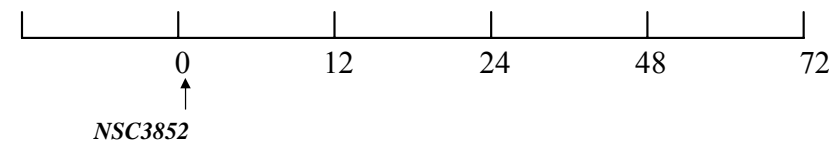

Cell cycle distribution in untreated MCF-7 cells

\begin{tabular}{|l|l|l|l|}
\hline \multicolumn{3}{|c|}{32} & 47 \\
\hline $\mathbf{G}_{\mathbf{1}}$ & $\mathbf{S}$ & $\mathbf{G}_{\mathbf{2}}$ & $\mathbf{G}_{\mathbf{1}}$ \\
\hline
\end{tabular}

Figure 13. Temporal relationship between cell plating time, treatment time and the MCF-7 cell cycle phase. 


\subsection{NSC3852 induces accumulation of hypophosphorylated pRb in MCF-7 cell.}

The retinoblastoma tumor suppressor protein $(\mathrm{pRb})$ is a cell cycle - regulated protein. It is phosphorylated at specific points of $\mathrm{G}_{1}$ phase of the cell cycle. As a consequence of its phosphorylation and dephosphorylation pattern, $\mathrm{pRb}$ acts as a switch for cell cycle progression from $\mathrm{G}_{1}$ into $\mathrm{S}$ phase. Hypophosphorylated $\mathrm{pRb}$ represses cell cycle progression by binding members of E2F family proteins and actively repressing transcription from E2F responsive genes. At the $\mathrm{G}_{1} / \mathrm{S}$ phase boundary, $\mathrm{pRb}$ becomes hyperphosphorylated and loses its growth inhibitory function, permitting cell progression into S phase (Tiziana Tonini et al, 2002). We hypothesized that NSC3852 cause cell cycle arrest by inducing accumulation of hypophosphorylated $\mathrm{pRb}$ in breast cancer cells. The purpose of this experiment was to test whether NSC compounds cause accumulation of hypophosphorylated $\mathrm{pRb}$ and how rapidly $\mathrm{pRb}$ is shifted to its hypophosphorylated form.

Figure 14 shows that by 6 hours in the control cells $\mathrm{pRb}$ was represented mostly by its hyperphosphorylated form. At 12 hours there is a shift of $\mathrm{pRb}$ from its hypophosphorylated form to phosphorylated form. As expected, while cells were progressing through the $\mathrm{G}_{1}$ phase of cell cycle, $\mathrm{pRb}$ in the control cells was in its phosphorylated form (24hr.). Hypophosphorylated $\mathrm{pRb}$ appears again in the control cells by 48 hours, when cells are in the S phase of the cell cycle (Figure 13). NSC3852 increased hypophosphorylated $\mathrm{pRb}$ levels in MCF-7 breast cancer cells compared to control. Control levels of hypophosphorylated $\mathrm{pRb}$ at $6,12,24,48$ hour time point were 
set to $100 \%$. Hypophosphorylated pRb levels in cells exposed to NSC3852 for 6, 12, 24

or 48 hours increased to $153 \%, 184 \%, 190 \%$ and $128 \%$ compared to control levels, respectively. 


\section{Figure 14. NSC3852 induced changes in pRb phosphorylation state}

Synchronized MCF-7 cells were sub-cultured in DMEM/5\% FBS. After 12 hour incubation solvent control (C) or $10 \mu \mathrm{M}$ concentrations of NSC3852 (T) were added. Cells were then harvested for Western blots at the times indicated. Data shown in the bar graph are the mean hypophosphorylated $\mathrm{pRb}$ protein signals $+/-$ S.E.M. of $\mathrm{n}=1-3$ experiments. Statistically significant differences in hypophosphorylated $\mathrm{pRb}$ level $(\mathrm{p}<0.05)$ between control and drug treated cells are indicated by $*$. 

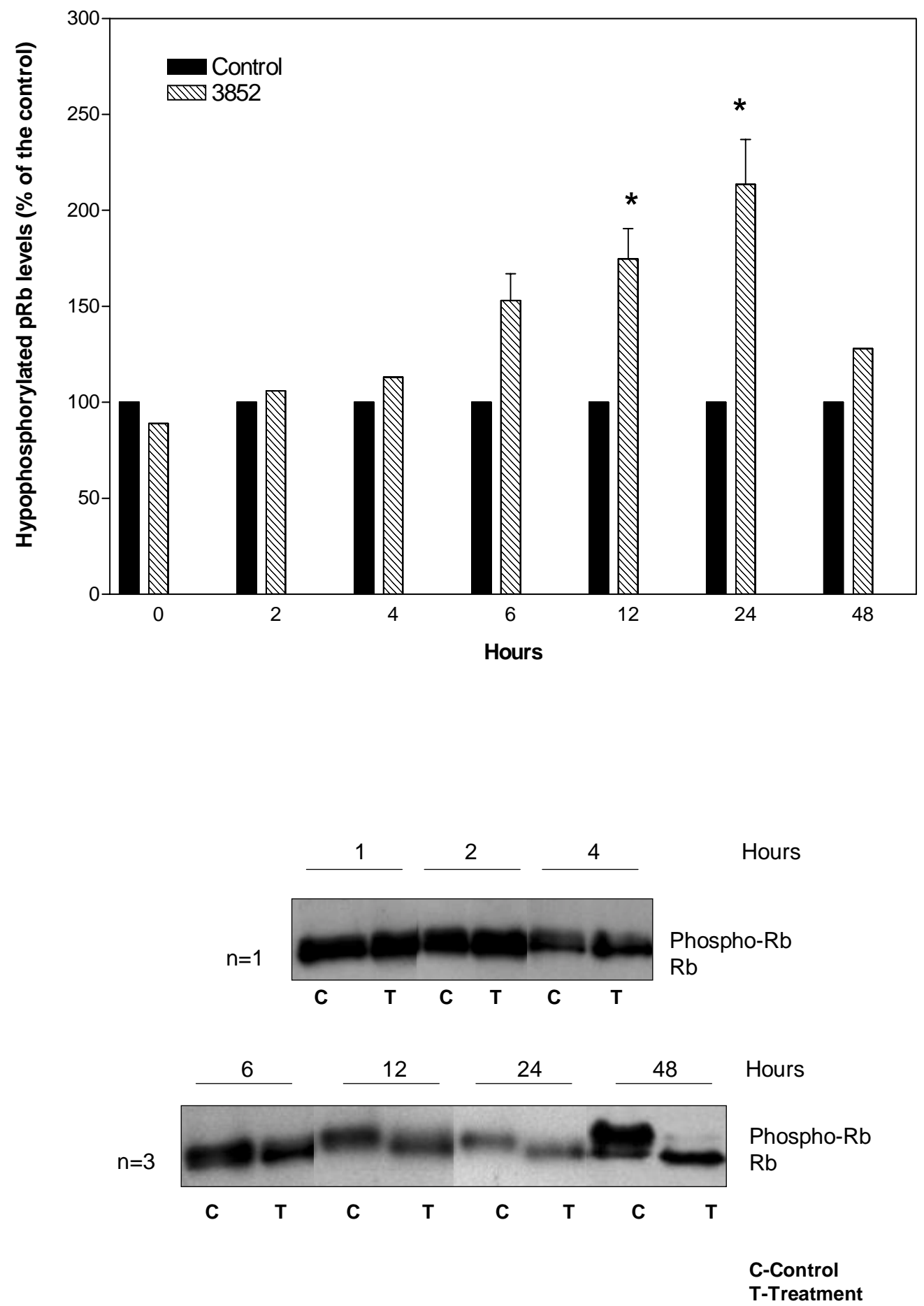


\subsection{NSC3852 causes suppression of E2F-1 protein in MCF-7 cells}

In the next experiment we tested the ability of NSC3852 to downregulate protein levels of the E2F-1 transcription factor.

As shown in Figure 15, levels of E2F-1 protein in the control cells increased at the 12 and 24 hour time points. Upon the cell cycle progression (48 hour) E2F-1 levels in the control decrease (lane 7). Immunoblot analysis demonstrated reduction in E2F-1 protein levels after 12 hours (54\% of the control) in the cells exposed to NSC3852 compared to control (Figure 15). By 24 and 48 hours in NSC3852 levels of E2F-1 were reduced by $57 \%$ and $67 \%$ compared to control, respectively. This results support the hypothesis that suppression of E2F-1 protein level is a mechanism that might contribute to cell growth inhibition and differentiation caused by NSC3852, by preventing the induction of genes necessary for cell cycle progression (c-myc, E2F-1, cdc25A, cyclin E, B-myb). 
Figure 15. Downregulation of E2F-1 protein level by NSC3852: Synchronized MCF-7 cells were sub-cultured in DMEM/5\% FBS. After 12 hour incubation solvent, control (C) or NSC3852 (T) at $10 \mu \mathrm{M}$ concentration was added. Cells were then harvested for Western blots at the times indicated. Data shown in the bar graph are the mean E2F-1 protein signals + - S.E.M. of $n=3$ experiments. Control levels were set to $100 \%$ at each time point. Statistically significant differences in E2F levels $(p<0.05)$ between control and NSC3852 treated cells are indicated by $*$. 

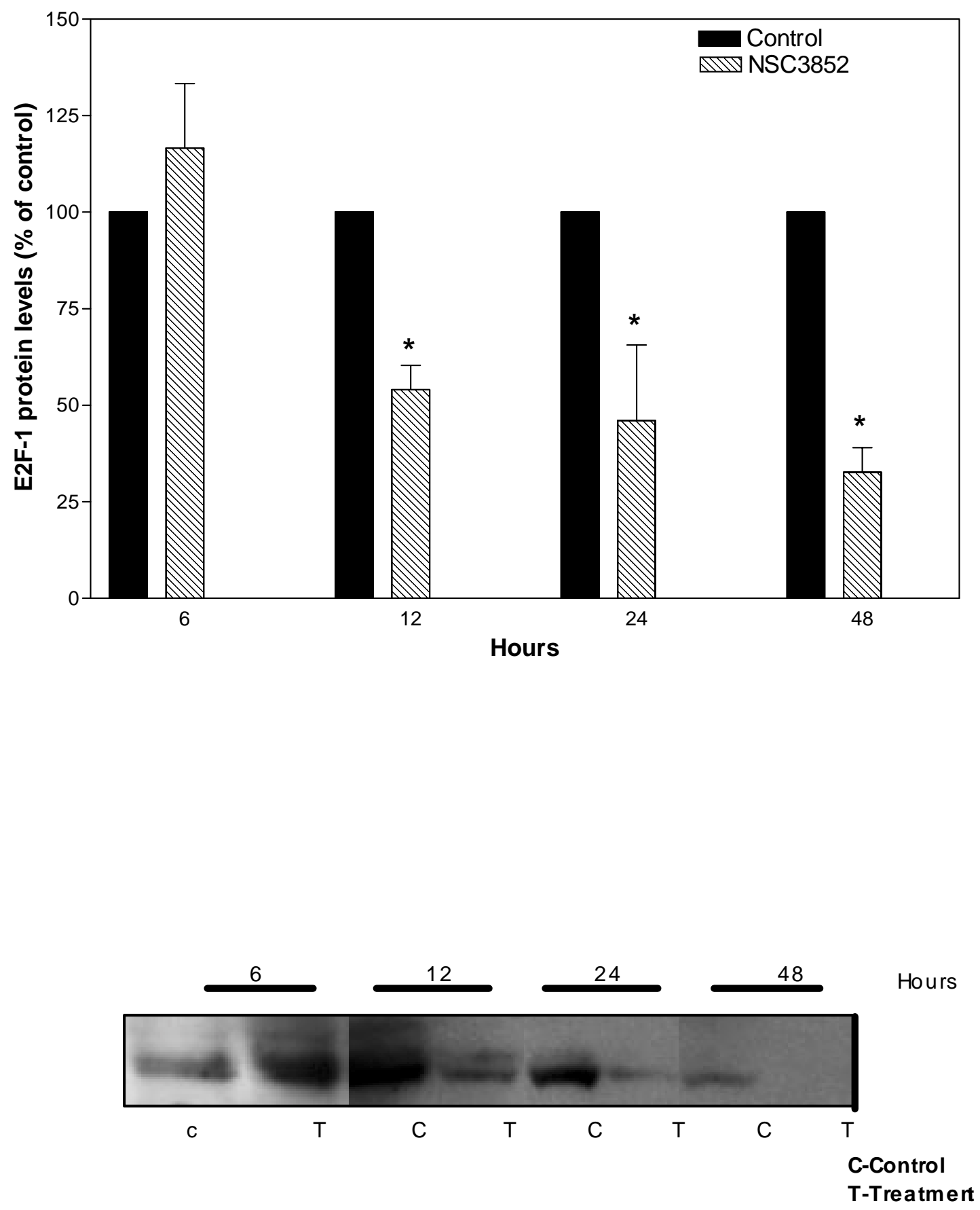


\subsection{Immunoblot analysis of E2F protein family members}

The E2F family is divided into three subgroups - transcriptional activators (E2F-1, E2F-2 and E2F-3), transcriptional repressors (E2F4 and E2F-5), and a unique-acting transcriptional repressor (E2F-6) (J. M. Trimarchi et al, 2001)). To assess the effect of NSC3852 on different E2F family members in MCF-7 cells western blot analysis of E2F2, E2F-3, E2F-4, E2F-5 and E2F-6 was performed.

Figure 16 indicates that MCF-7 cells express all of the E2F family members. A 24 hour exposure to NSC3852 did not change the protein levels of E2F-2, E2F-3, E2F-4 or E2F5. This finding suggests that among E2F family proteins, E2F-1 is a relatively selective target of NSC3852. 

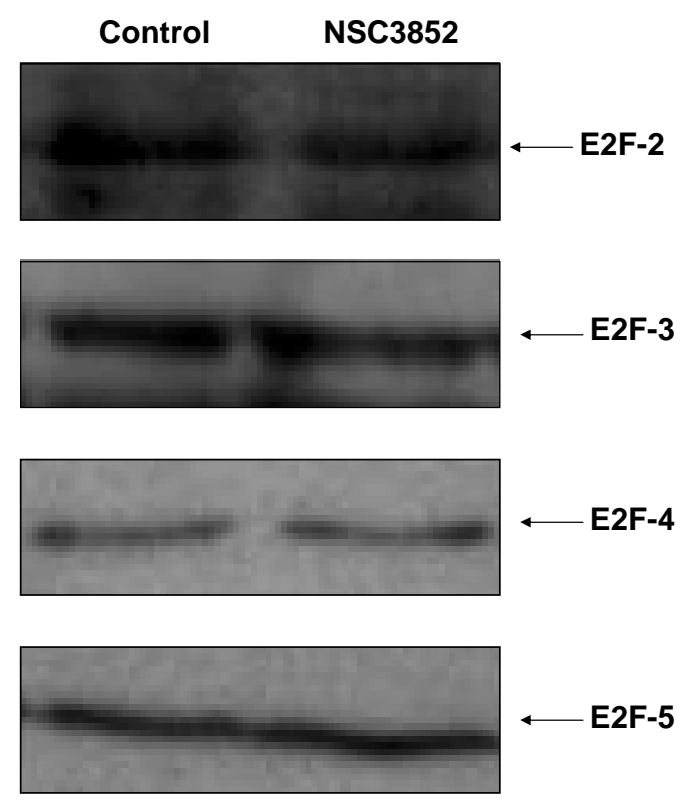

Figure 16. Effect of NSC compounds on E2F family members: MCF-7 cells were plated at the density of $2 \times 10^{6}$ cells per $60 \mathrm{~mm}^{2}$ tissue culture dish in $5 \mathrm{ml}$ of DMEM/5\% FBS medium. Cells were left to attach for 12 hours. Solvent (DMSO) or 10 $\mu$ M NSC3852 were added to the dishes. Cells were harvested in protein harvesting buffer after 24 hour incubation. Proteins levels were detected using chemiluminescent autoradiography and quantitated using FluorChem (Alpha Innotech, San Leandro, CA) spot densitometry. $n=1$ 


\subsection{Accumulation of hypophosphorylated form of pRb induced by NSC3852 leads to an increase in $\mathrm{pRb} / \mathrm{E} 2 \mathrm{~F}-1$ complex formation}

The objective of this experiment was to test whether accumulation of hypophosphorylated form of $\mathrm{pRb}$ induced by NSC3852 leads to the increase in $\mathrm{pRb} / \mathrm{E} 2 \mathrm{~F}$ complex formation in MCF-7 cells.

Immunoprecipitation of cell lysates was performed using E2F-1 antibodies, and subsequent immunoblotting with $\mathrm{pRb}$ revealed $\mathrm{E} 2 \mathrm{~F}-1 / \mathrm{pRb}$ complex. Control cells (Figure 17) exhibited very low levels of E2F-1/pRb complex (lane1). pRb/E2F-1 complex formation increased more then two times after treatment with NSC3852. This finding suggests that indeed there is an increase in $\mathrm{pRb} / \mathrm{E} 2 \mathrm{~F}-1$ complex formation in cells treated with NSC 3852 regardless of the decrease of total E2F-1 protein levels in cells. The results suggest that free E2F-1 in 3852 treated cells is very low. 

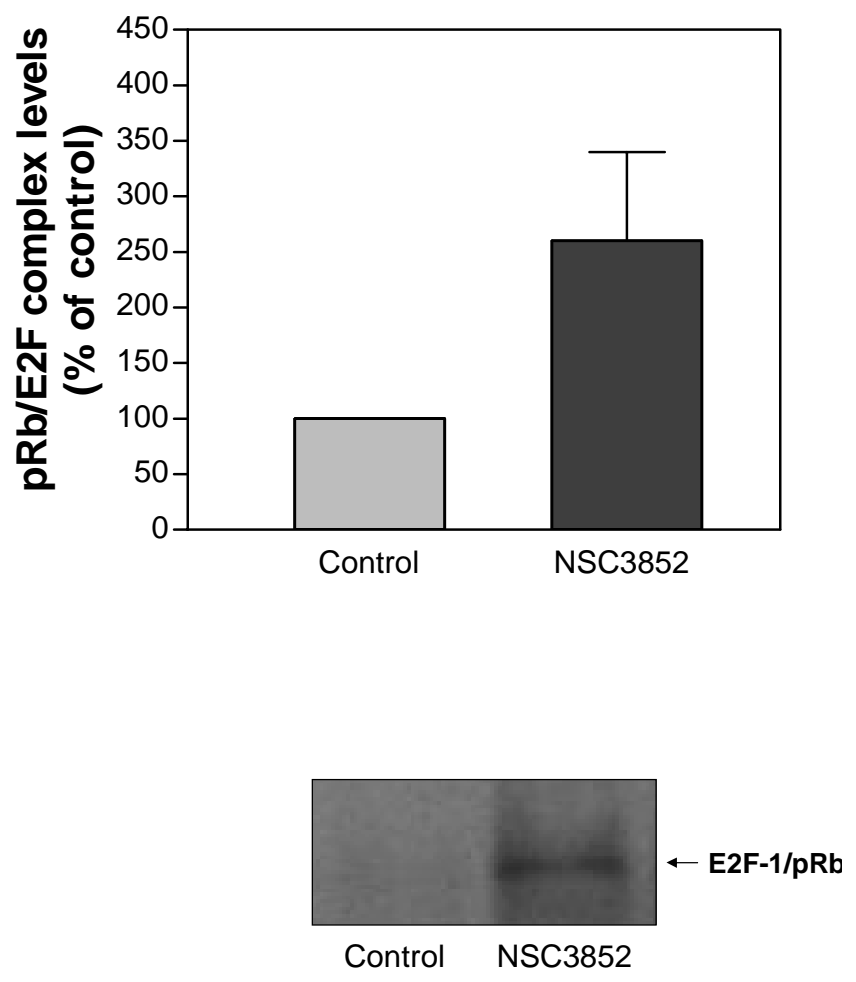

Figure 17. NSC compound increased pRb/E2F-1 complex formation: $3 \times 10^{6} \mathrm{MCF}-7$ cells were plated in DMEM / 5\% FBS culture medium. After 12 hour incubation 10uM NSC 3852 or solvent control were added to the cells for 40 hours. Cells were harvested in harvesting buffer. IP was performed with whole cell extracts. Antibodies to E2F-1 were used for primary IP, and immunoprecipitates were then probed by immunoblotting for $\mathrm{pRb} . \mathrm{n}=2$ 


\subsection{Suppression of Myc protein by NSC3852 in MCF-7 cells}

Myc is a transcriptional target of E2F-1. Regulation of c-myc oncogene expression plays an important role in control of cell proliferation and differentiation. There are two E2F-1 consensus DNA - binding sites in the c-myc gene promoter (Hiebert, S. W. et al., 1989). Furthermore, it has also been reported that overexpression of Myc can simulate the expression of E2F-1 protein (Leone, G. et al., 1997). We hypothesized that downregulation of free E2F-1 by NSC3852 and also increased E2F$1 / \mathrm{pRb}$ complex might cause decreased Myc protein levels.

Figure 18 shows that Myc levels in the control cells increased between 12-48 hours (lane 1,3 and 5). Myc protein was downregulated by NSC compounds after 24 and 48 hours of treatment by $\sim 50 \%$ and $60 \%$ respectively (Figure 18 ). These results and previous finding support our hypothesis that Myc protein, a downstream regulator of E2F-1, may be downregulated as a result of suppression of E2F-1 levels and the increase in $\mathrm{E} 2 \mathrm{~F}-1 / \mathrm{pRb}$ complex induced by NSC3852 . 
Figure 18. Downregulation of Myc protein level by NSC3852: Synchronized MCF-7 cells were sub-cultured in DMEM/5\% FBS. After 12 hour incubation, solvent control or NSC3852 $(10 \mu \mathrm{M})$, respectively were added. Cells were then harvested for Western blots at the times indicated. Data shown in the bar graph are the mean Myc protein signals + - S.E.M. of $n=3$ experiments. Statistically significant differences in Myc signal $(\mathrm{p}<0.05)$ between control and NSC3852 treated cells are indicated by *. 

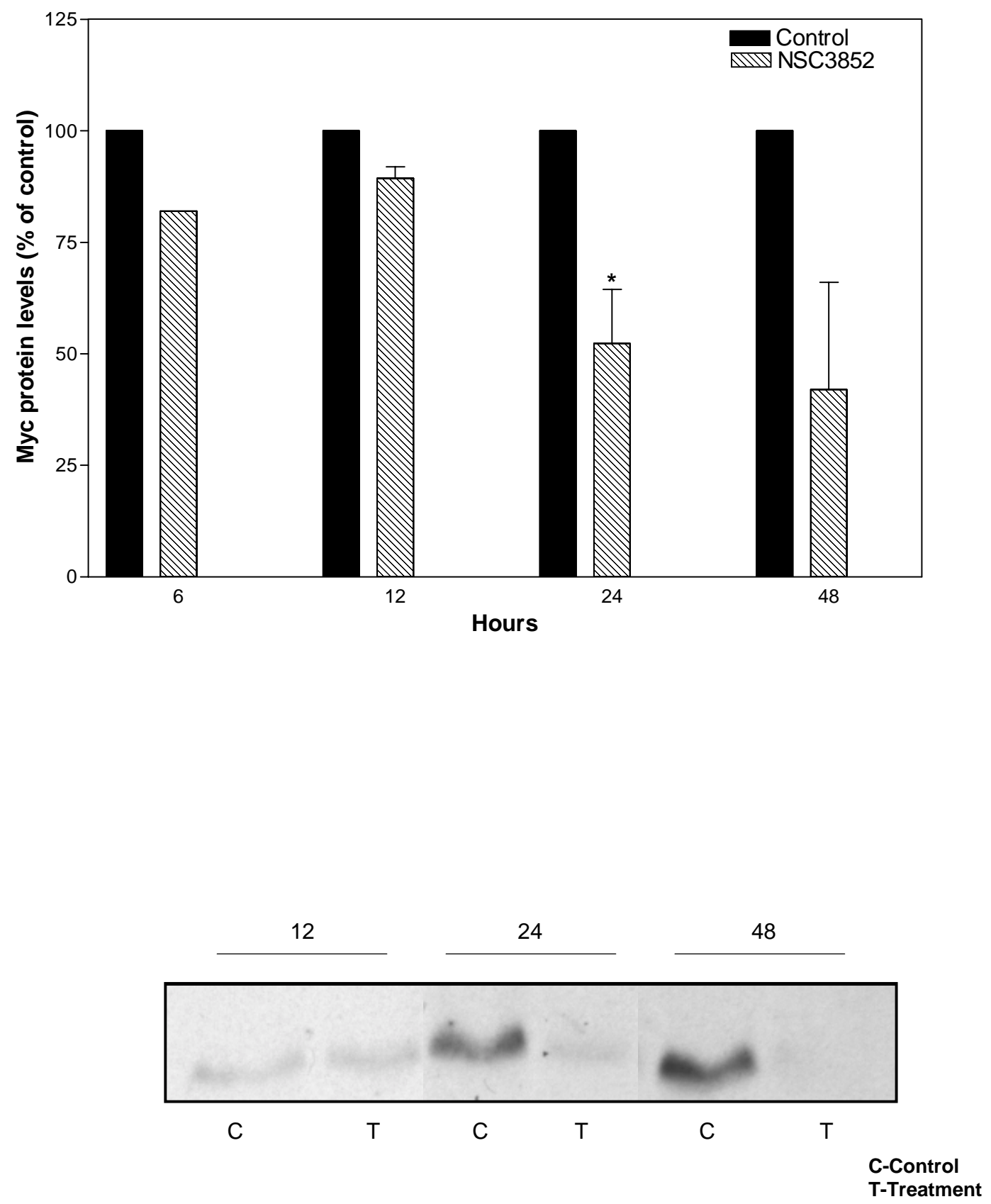


\subsection{NSC3852 influence on E2F-1 and Myc transcriptional activity}

Our previous results showed that NSC3852 induced accumulation of hypophosphorylated $\mathrm{pRb}$, downregulated of E2F-1, increased E2F-1/pRb complex formation and suppressed Myc protein levels. A transiently transfected reporter gene was assayed to test whether transcriptional activity of E2F-1 and Myc proteins is downregulated by NSC3852.

Results obtained from reporter gene assay are presented in Figure 19. Activation of E2F-1 and Myc response elements was measured by assaying for the luciferase reporter gene. Activity of E2F-1 and Myc response elements in the control cells was set to $100 \%$. Our results indicate that by 24 hours NSC3852 suppressed activity of E2F-1 and Myc response elements by $32 \%$ and $41 \%$, respectively. These results are important, because they demonstrate that, as we predicted, after 24 hours of treatment with NSC3852 transcriptional activity of E2F-1 and Myc is significantly downregulated. 


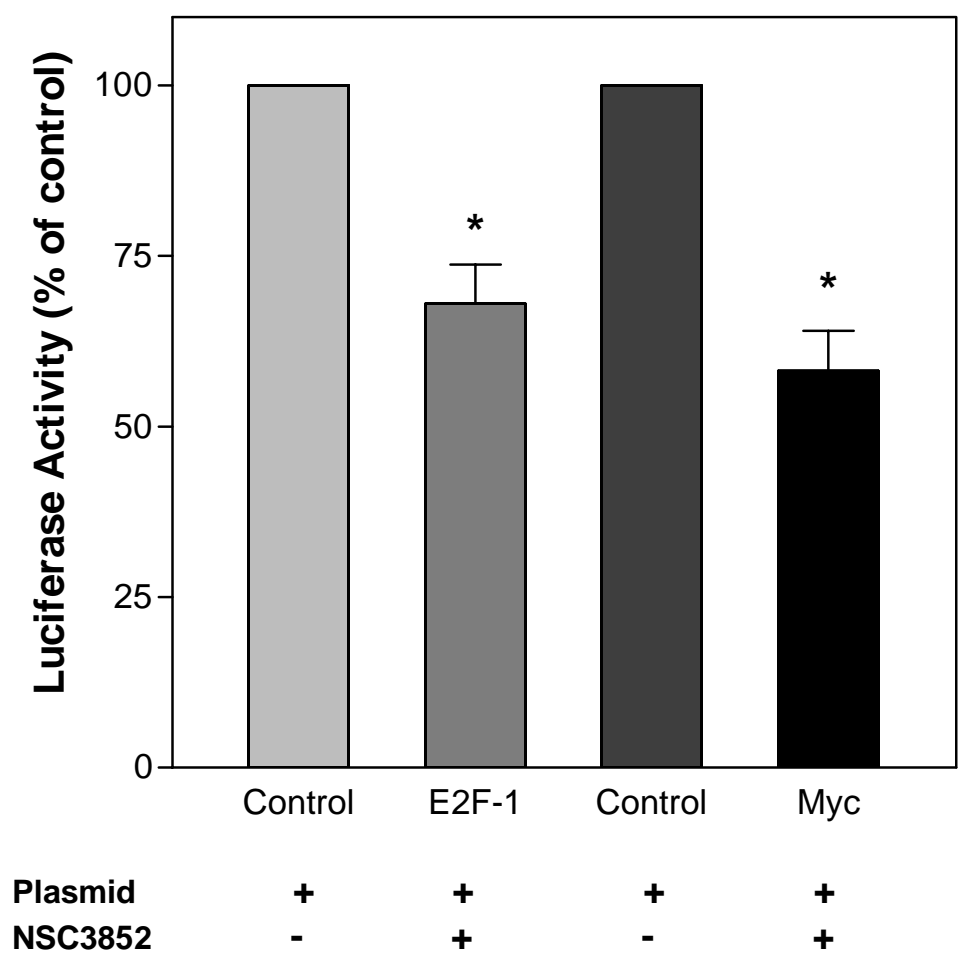

Figure 19. NSC compounds affect E2F-1 and Myc transcriptional activity: MCF-7 cells were transfected with 2.5ug/dish of E2F-TA-Luc and Myc-TA-Luc plasmids. Transfection was terminated by aspirating medium and adding $5 \mathrm{ml}$ of the fresh medium \pm NSC $3852(10 \mathrm{uM})$ or solvent control. After 24 hours, cell extracts for luciferase assay were prepared. Data shown in the bar graph are the mean +/- S.E.M. of $n$ $=3-5$ experiments. Statistically significant differences $(p<0.05)$ between control and NSC3852 treated cells are indicated by *. 


\subsection{Significant findings}

NSC3852 was chosen as a lead compound for the further investigation. The purpose of the experiments discussed in the second chapter was to test how NSC3852 regulates the pRb/E2F-1/Myc pathway. In summary, our results show that NSC3852 induced accumulation of hypophosphorylated $\mathrm{pRb}$ with the subsequent increase in $\mathrm{E} 2 \mathrm{~F}-1 / \mathrm{pRb}$ complex formation in MCF-7 cells. NSC3852 selectively suppressed levels of E2F-1 protein among all the members of E2F family. Myc protein levels were also significantly downregulated by NSC3852. A reporter gene assay was performed to test the effect of NSC3852 on E2F-1 and Myc proteins transcriptional activity showed that after 24 hours of treatment with NSC3852 transcriptional activity of E2F-1 and Myc is significantly downregulated. 


\section{Chapter 3. NSC 3852 affect redox status of MCF-7 human breast cancer cell}

It has been found that the redox potential $\left(\mathrm{E}_{\mathrm{c}}\right)$ of normal proliferating cells is below that of cancer cells. $\mathrm{E}_{\mathrm{c}}$ can be calculated from the ratio of GSH (glutathione) / GSSG (glutathione disulfide). Furthermore, several studies reported that elevated redox potential cause the accumulation of $\mathrm{pRb}$ in its hypophosphorylated form by preventing the phosphorylation of $\mathrm{pRb}$ protein, which in turn does not release E2F-1 protein and subsequently transcription factors necessary for the progression of the cell cycle are not synthesized (A. Hoffman et al., 2001). We hypothesize that NSC3852 caused mild oxidation of the breast cancer cells, and through this mechanism induces hypophosphorylation of $\mathrm{pRb}$, growth arrest and differentiation (Figure 20). To test this hypothesis we tested whether N-acetylcysteine (NAC), a GSH precursor, could reverse the activities of NSC3852. It has been shown that N-acetylcysteine restores $\mathrm{pRb}$ phosphorylation caused by depletion of intracellular GSH (Yamauchi A. et al., 1997). This information provides a rationale to test the effect of NAC on the cells treated with NSC3852. 


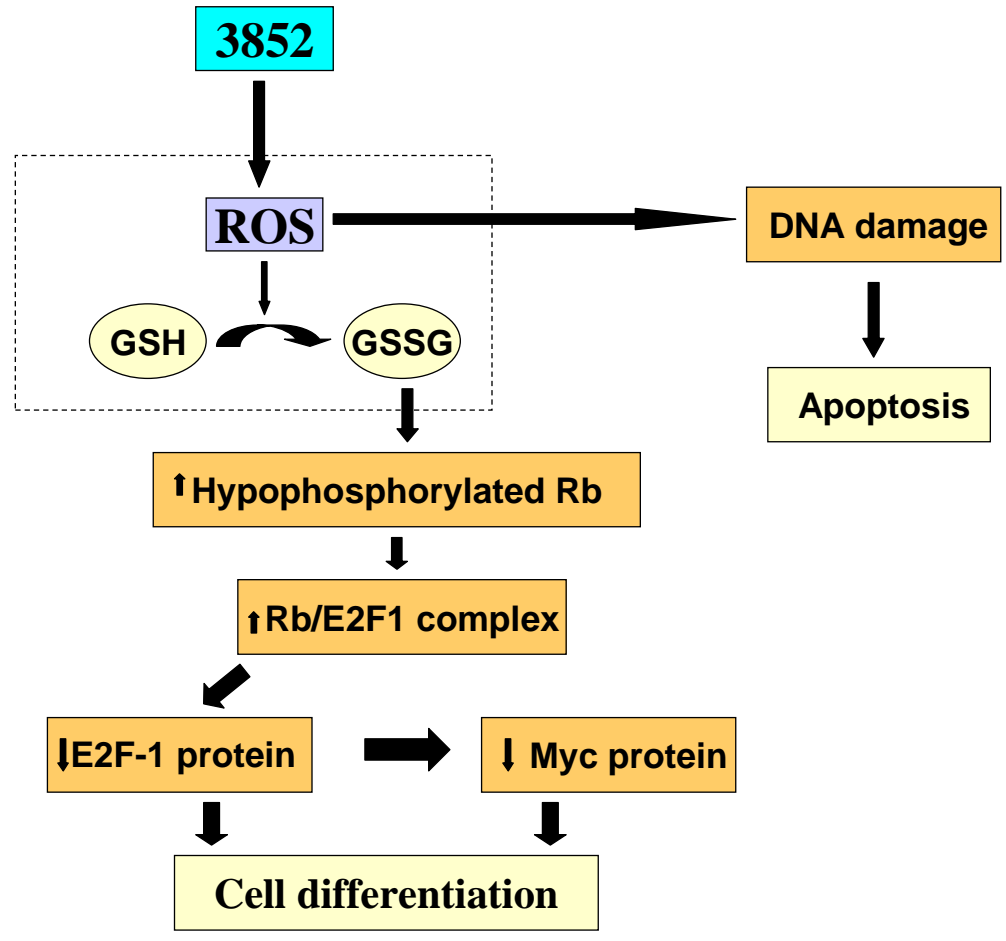

Figure 20. Model: NSC3852 mechanism of action. 


\subsection{Modulation of $\mathrm{pRb} / \mathrm{E} 2 \mathrm{~F}-1 / \mathrm{Myc}$ pathway by NSC3852 can be blocked by pretreatment of MCF-7 cells with NAC}

Several studies reported that elevated redox potential caused the accumulation of $\mathrm{pRb}$ in its hypophosphorylated form by preventing the phosphorylation of $\mathrm{pRb}$ protein, which in turn does not release E2F-1 protein and subsequently transcription factors necessary for the progression of the cell cycle are not synthesized (A. Hoffman et al., 2001). Western blotting was used to test whether NAC blocks the effect of NSC3852 on pRb, E2F-1 and Myc proteins. In these experiments NSC2039, a structural analog of NSC3852 lacking the nitrosyl moiety, was used as a negative control. NSC2039 is unable to cause cell cycle arrest (Table 2) in MCF-7 cells.

Figure 21 shows that one hour pretreatment with NAC blocked accumulation of hypophosphorylated pRb induced by 24 hour NSC3852 treatment. NAC also protected E2F-1 and Myc protein from NSC3852 induced downregulation (Figure 21). These results support the hypothesis that NSC3852 induced changes involve a NAC sensitive redox pathway. As predicted, NSC2039 did not affect the pRb/E2F-1/Myc pathway. 
Figure 21. NAC reverses the effect of NSC3852 on Rb/E2F-1/Myc pathway: Synchronized MCF-7 cells were plated in $60 \mathrm{~mm}^{2}$ dishes in $5 \mathrm{ml}$ DMEM/5\% FBS at density $2 \times 10^{6}$ cells per dish. Twelve hours later cells were pretreated with NAC for 1 hour. NSC3852 $(10 \mu \mathrm{M})$ or NSC2039 $(8 \mu \mathrm{M})$ was added after the pretreatment, for 24 hours. Cells were then harvested for Western blots. Proteins were resolved on $10 \%$ polyacrylamide gels $(80 \mu \mathrm{g}$ of each sample) and probed with antibodies to $\mathrm{pRb}, \mathrm{E} 2 \mathrm{~F}-1$ and Myc. Data shown in the bar graph are the mean protein signals +/- S.E.M. of $n=2-3$ experiments. Statistically significant differences are indicated by*. 

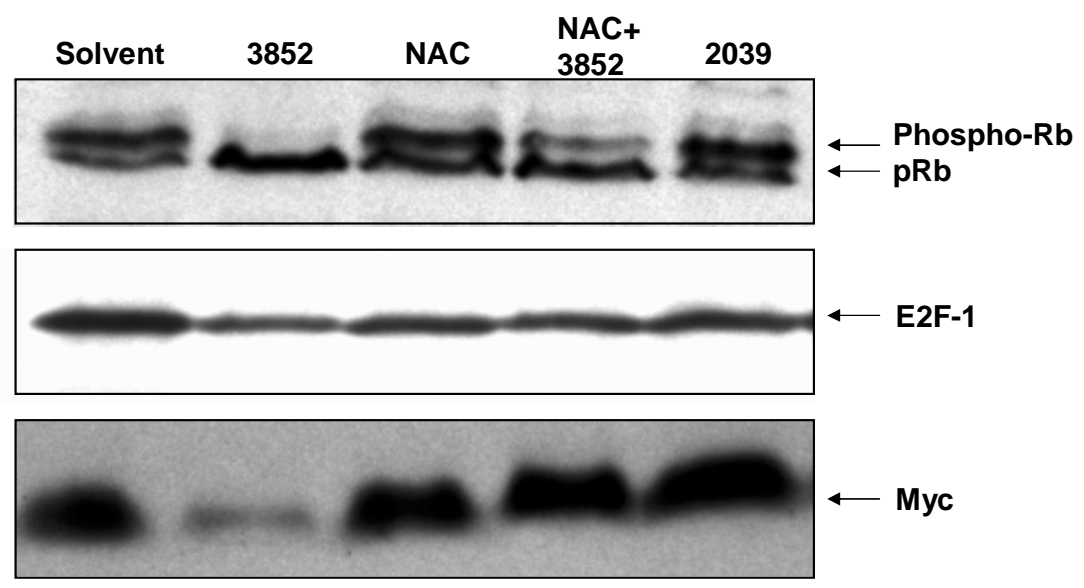


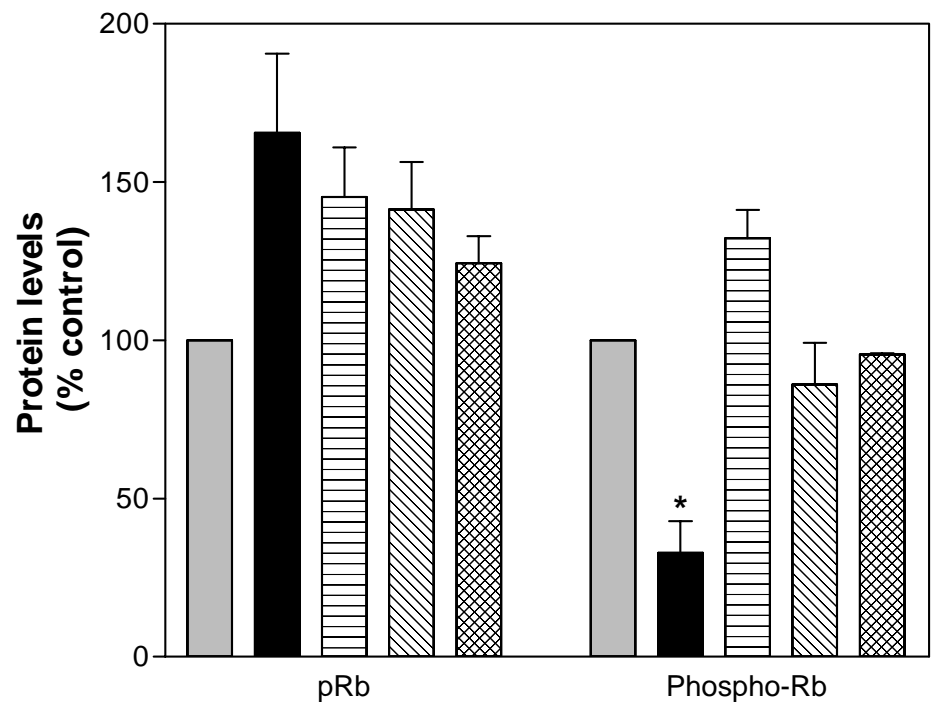

$\square$ Control

3852

MIV NAC+3852

$\Longrightarrow$ NAC

2039
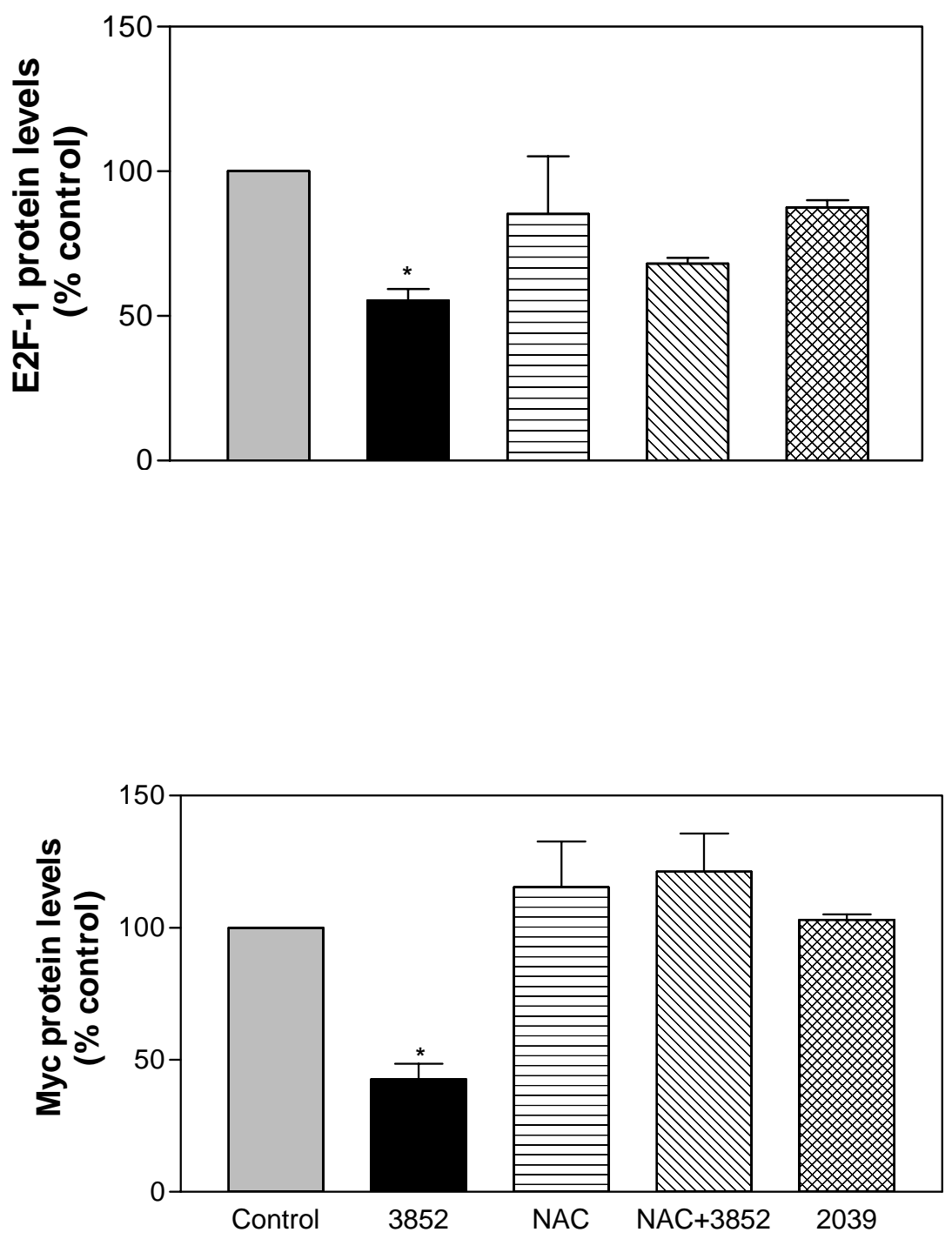


\subsection{Effect of NAC on Ki-67 index in NSC3852 treated cell}

As our results indicated (section 1.3.), NSC3852 was able to significantly shift proliferating MCF-7 cells into $\mathrm{G}_{0}$ phase after 48 hours of treatment. Based on the fact that modulation of $\mathrm{pRb} / \mathrm{E} 2 \mathrm{~F}-1 / \mathrm{Myc}$ pathway (major pathway, which regulates cell cycle progression from $\mathrm{G}_{1}$ into $\mathrm{S}$ phase) by NSC3852 was reversed by NAC (Figure 21), we predicted that NAC would block increase in proportion of $\mathrm{G}_{0}$ cells in the population of MCF-7 cells treated with NSC3852. Ki-67 antigen was used previously as a marker of cell proliferation, as it can not be detected in non proliferating cells.

Our results (Figure 22) indicate that control dishes contained 6\% of Ki-67 negative cell. NSC3852 induced a significant increase (37\%) in Ki-67 negative cells after 48 hours of treatment. NAC alone did not cause changes in Ki-67 negative cell. Dishes pretreated with NAC for 1 hour and then treated with NSC3852 for 48 hours contained $17 \%$ of Ki67 negative cells. This data indicate that NAC partially blocked the NSC3852 induced shift of proliferating cells into $\mathrm{G}_{0}$ phase. 


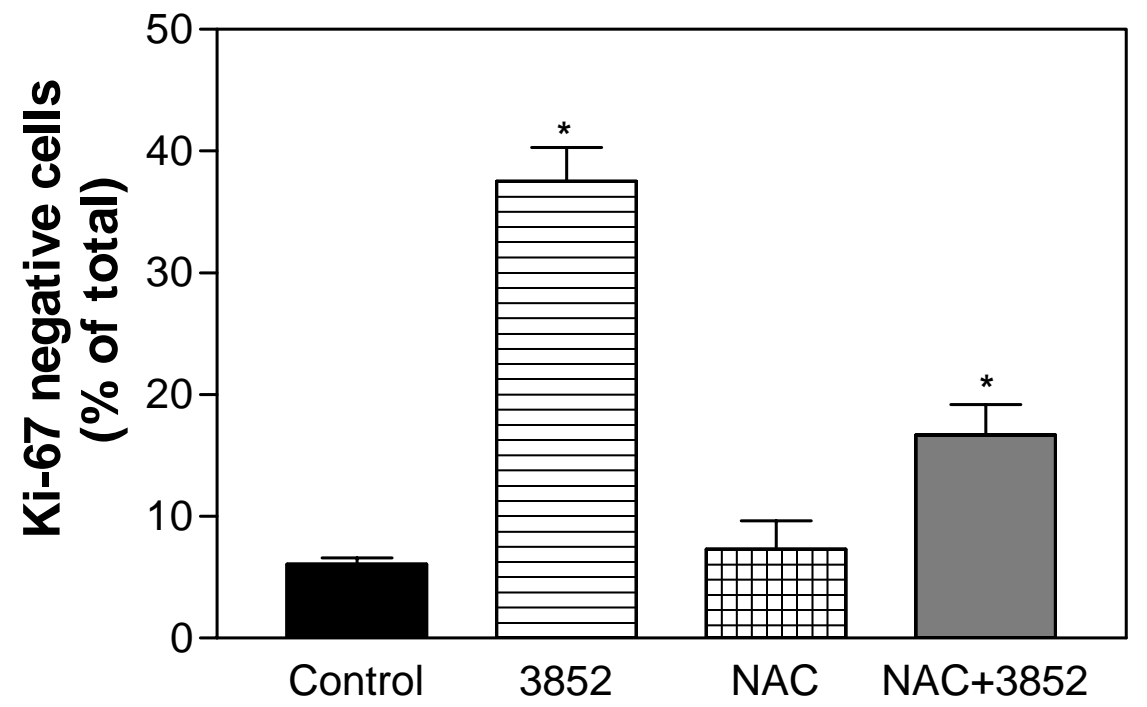

Figure 22. Effect of NAC on Ki-67 index in NSC3852 treated cells: 2 x 105 MCF-7 cells were plated in DMEM / 5\% FBS culture medium. Cells were grown for 12 hours, pretreated with NAC $(5 \mathrm{mM})$ for 1 hour and then NSC3852 $(10 \mu \mathrm{M})$ was added. Forty eight hours later cells were assayed for Ki-67 immunoreactivity. A minimum of 500 cells were counted per slide. Data are the mean $+/$ - S.E.M. of $n=3$ experiments. Statistically significant differences are indicated by *. 


\subsection{NAC protects MCF-7 cells from DNA damaging effect of NSC3852}

To determine the time point at which DNA damage induced by NSC3852 is most severe we assayed DNA damage every 24 hours for 5 days. Figure 23 demonstrates that NSC3852 induced DNA damage was detectable at 12 hours, and peacked at 24 hours, at subsequent time points DNA damage decreased and was not detectable by 96 hours (Figure 23A). These results together with data shown in Figure 10 suggest that NSC3852 induced DNA damage precedes cell apoptosis.

Oxidative stress is known to cause DNA damage (Guetens G. et al.,2002). The thiol Nacetylcysteine is a precursor of intracellular cysteine and glutathione, and thus buffers cells from alterations of the redox status, as well as oxidative DNA damage (De Flora S. et al., 2001). To test our hypothesis that NAC can block NSC3852 induced DNA damage, we pretreated MCF-7 cells with 5mM NAC for 1 hour. After the pretreatment, NSC3852 or NSC2039 (negative control) was added to the cells. The Comet assay was performed 24 hours later to quantify DNA damage in MCF-7 cells. NAC blocked the DNA damaging effect of NSC3852 (Figure 23B). As predicted, NSC2039 did not induce DNA damage in MCF-7 cells after 24 hours of treatment. 


\section{Figure 23. NAC protects MCF-7 from DNA damage caused by NSC3852.}

A) MCF-7 cells $\left(1 \times 10^{5} / 35 \mathrm{~mm}^{2}\right.$ dish $)$ were treated with $10 \mu \mathrm{M}$ NSC3852. DNA damage induced by NSC3852 was assayed at times indicated. Data shown are pooled results of two independent Comet experiments.

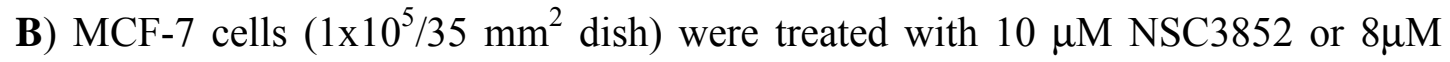
NSC2039. Twenty four hours later cells were assayed for DNA damage. The number of comets with tail moments in ranges between $0-2,5-10,10-20,20-50,50-100$ and $>100$ are plotted for each treatment group. Eighty cells were analyzed per experiment. Data shown are pooled results of the three independent Comet experiments in MCF-7 cells. Statistically significant differences are indicated $(* \mathrm{P}<0.05)$ 
A.

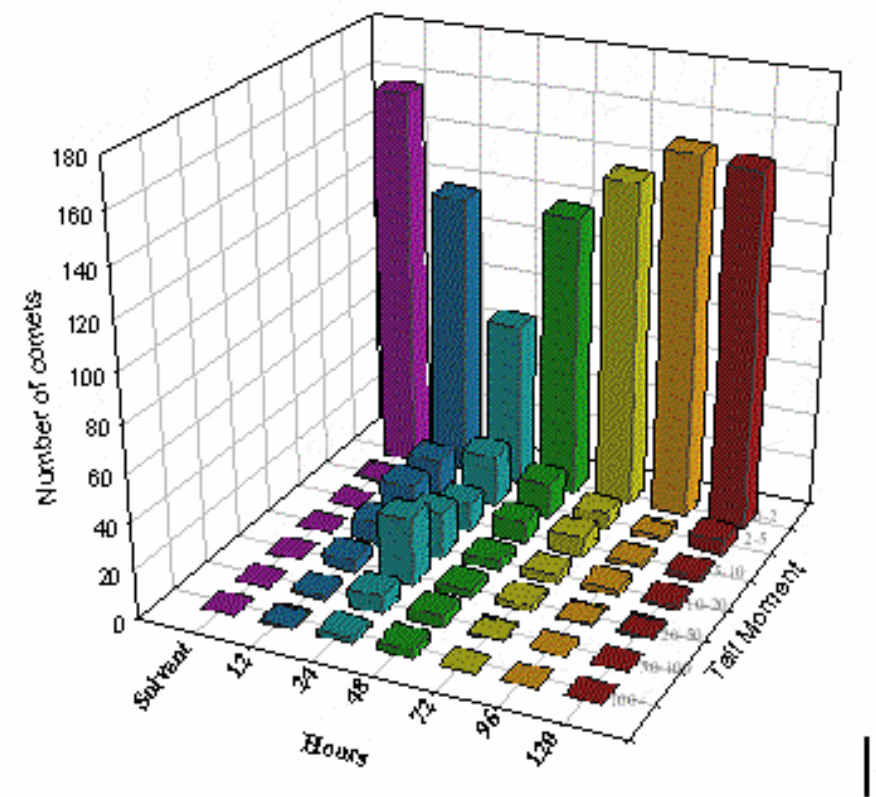

B.

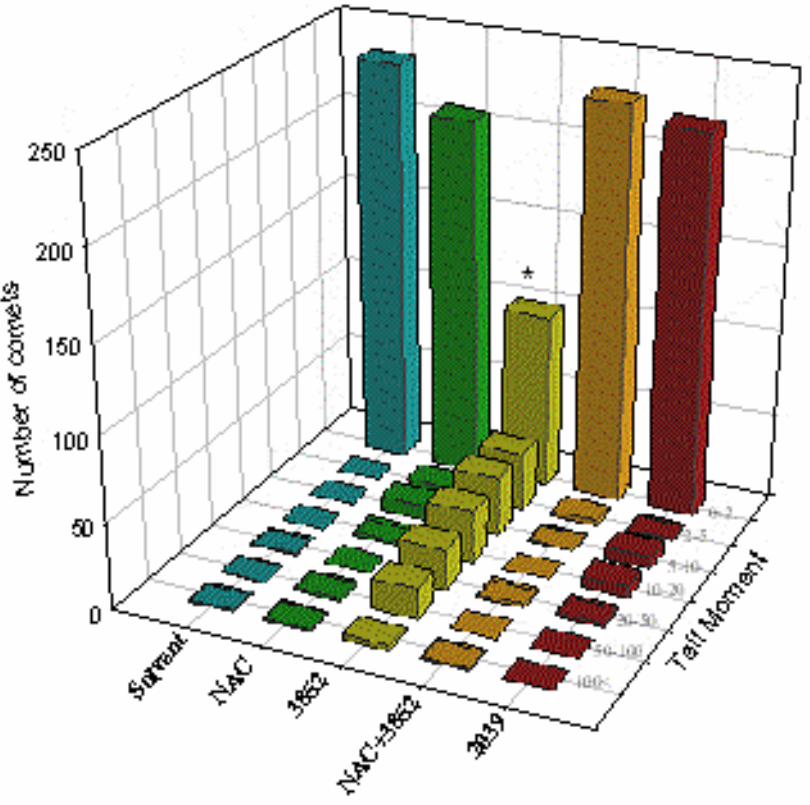




\subsection{NSC3852 induced apoptosis is blocked by NAC}

In the next set of experiments we used a cell death ELISA to test, whether NAC protected NSC3852 treated cells from apoptosis.

Apoptosis measured as a nucleosome release is reported here as the ratio of treated/control values. Nucleosome release values in control cells equal one. As shown in Figure 24, after 24 hours of treatments with NSC3852 no apoptosis was detected in MCF-7 cells. After 48 hours of treatment cells exposed to NSC3852 exhibited nucleosome release values equal to $\sim 3.5$. Cells stimulated with NSC3852 for 72 hour exhibited nucleosome release values equal to $\sim 2$. As we predicted, cells pretreated with NAC were completely protected from NSC3852 induced apoptosis. 

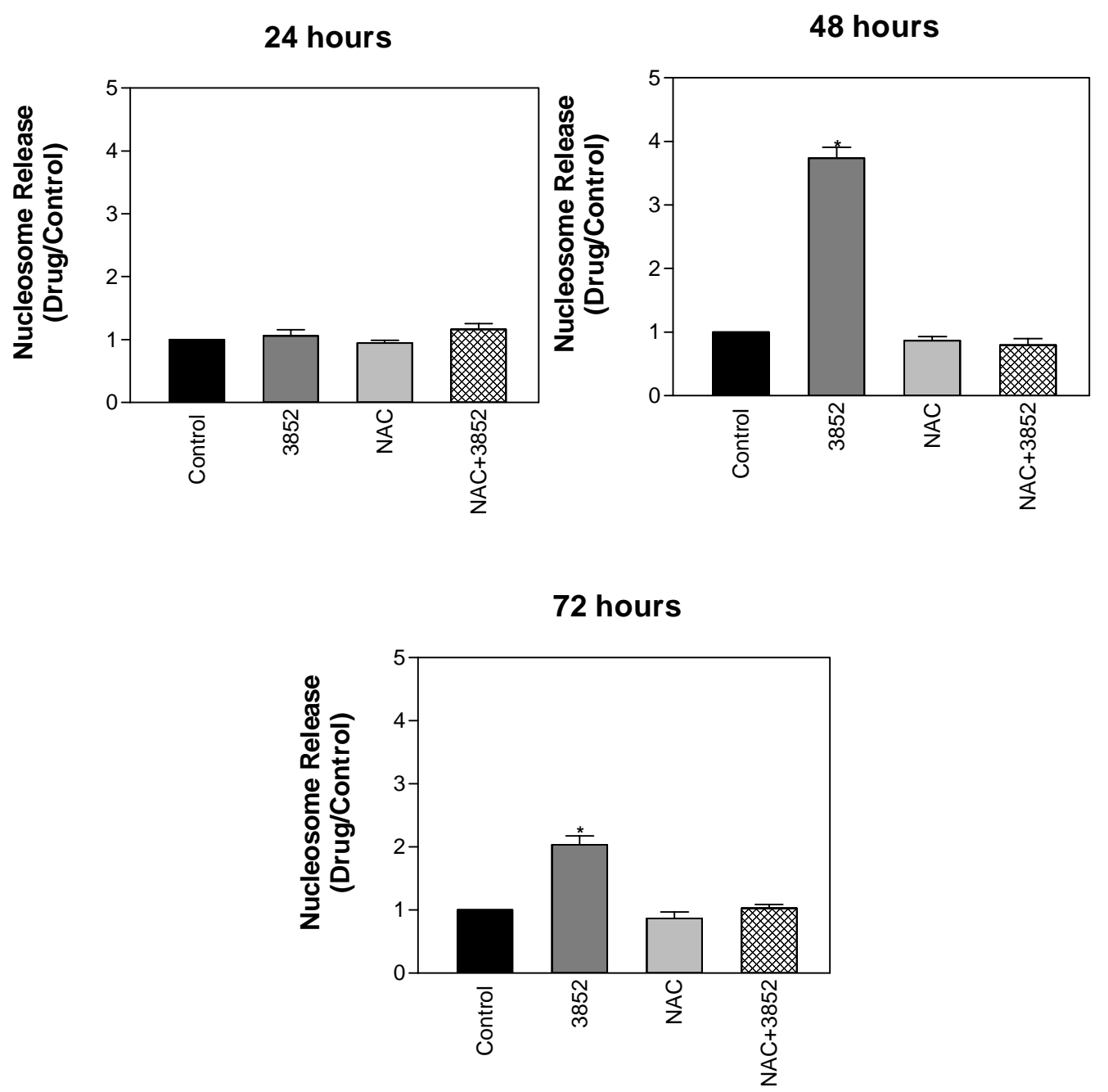

Figure 24. NAC blocks NSC3852 induced apoptosis. MCF-7 cell (4000 per well) were plated in 96-well plates. Twelve hours later test compounds were added. 24,48 or 72 hours later apoptosis was assayed using a nucleosome release ELISA. Apoptosis measured as a nucleosome release is reported here as the ratio of treated/control values obtained in a single experiment performed in triplicate. Statistically significant differences are indicated $(* \mathrm{P}<0.05)$. 


\subsection{NAC partially blocks growth inhibition of MCF-7 cells induced by NSC3852}

The goal of this experiment was to determine whether NAC would protect cells from growth inhibition induced by NSC3852 and test the effect of NSC2039 on MCF-7 cell growth.

The results are shown in Figure 25. Cell numbers in the control cultures increased more than 5 -fold by day four, and 13 -fold by day 7 . Cell growth was inhibited by $19 \%$ in the cells pretreated with NAC compared to control cells.

Initially, NSC2039 (compound structurally similar to NSC3852; it lacks nitroso substitution) had no effect on cell number, but was clearly toxic to cells after 48 hours. No surviving cells were detected in the dish after 6 days of treatment. It is worth mentioning that NSC2039 did not damage DNA in MCF-7 cells (section 3.2) after 24 hours of treatment and it had no effect on Rb/E2F-1/Myc pathway (Figure 21). All those characteristics suggest that NSC2039 has an effect distinctive action from NSC3852's effect on MCF-7 breast cancer cells.

As it is shown in Figure 25, NSC3852 suppressed growth of MCF-7 cells and this effect was partially reversed by NAC.

This data suggests that NAC restored cell growth effect is accounted in part to the cellular protection by NAC from NSC3852 induced apoptosis and cell cycle arrest (Figure 22, 24). However, there is NAC independent mechanism that modulates cell cycle and differentiation in cells treated with NSC3852 (Figure 29). 


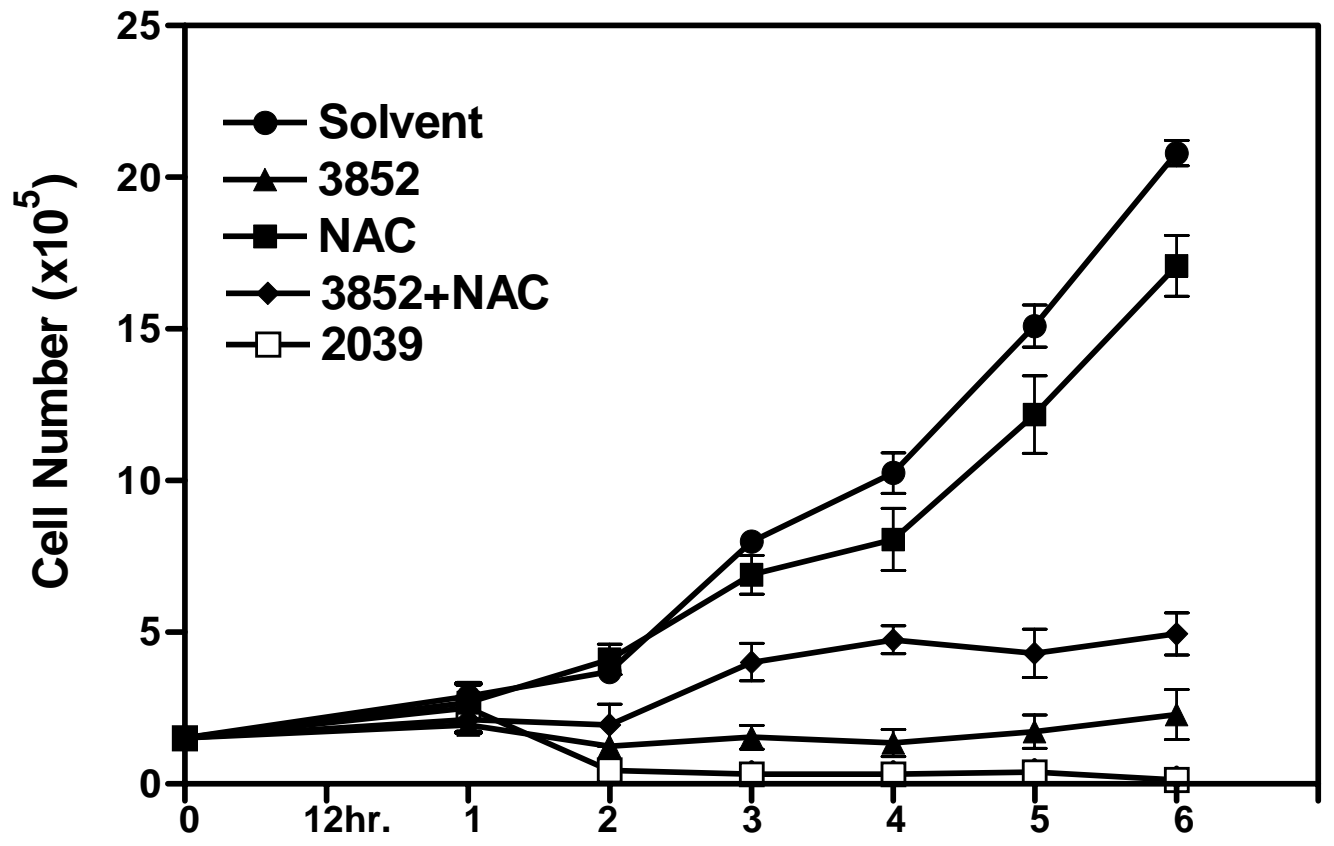

Figure 25. Growth curves: MCF-7 cells were plated at density 2 x $10^{5}$ per $35 \mathrm{~mm}$ dish. Cells were left to attach for 12 hours, and pretreated (where indicated) with NAC $(5 \mathrm{mM})$ for 1 hour. After one hour of pretreatment, NSC3852 $(10 \mu \mathrm{M})$ or NSC2039 were added. Cells were harvested and counted using a hemocytometer at the days indicated. Data represent the $n=2-5$ experiments. 


\subsection{NSC3852 mediates ROS generation in MCF-7 cells}

Based on the fact that NSC3852 induced changes involve NAC responsive redox pathway we hypothesized that NSC3852 mediates ROS generation in MCF-7 cells. The electron spin resonance (ESR) spin trapping technique was used to examine free radical generation mediated by NSC3852. Short-lived radicals react with a paramagnetic compound (spin-trap), in this case DMPO (5,5-dimethyl-1-pyrroline-N-oxide), and form a relatively long-lived product, the so-called spin adduct, which can be studied by ESR (G. M. Rosen et al., 1985).

MCF-7 cells treated with NSC3852 displayed a 1:2:2:1 quarter signal (with $\mathrm{a}_{\mathrm{H}}=$ $a_{N}=14.9 G$, where $a_{H}$ and $a_{N}$ denote hyperfine splitting of the $\alpha$ - hydrogen and the nitroxyl nitrogen, respectively), indicative of the DMPO-OH adduct, whereas MCF-7 cells treated with NSC2039 (negative control) did not generate such a signal (Figure 26A, B).

To test whether the observed signal is attributed to $\cdot \mathrm{O}_{2}{ }^{-}$trapping rather than to - $\mathrm{OH}$ derived from $\mathrm{H}_{2} \mathrm{O}_{2}$, SOD (superoxide dismutase) or catalase were added into the reaction mixture containing cells and NSC3852. Catalase, a scavenger of $\mathrm{H}_{2} \mathrm{O}_{2}$, had no effect on the observed signal, whereas SOD quenched the signal (Figure 26E, H). This result showed that the observed signal was attributable to $\bullet \mathrm{O}_{2}{ }^{-}$trapping.

There are two major cellular sources for production of $\mathrm{O}_{2}{ }^{-}$: flavoprotein containing NADPH oxidase complex and mitochondrial electron transport chain. To determine, which enzymes were involved in NSC3852 mediated formation of $\boldsymbol{O}_{2}{ }^{-}$, inhibitors of those enzymes were used. Rotenone $(50 \mu \mathrm{M})$ (mitochnodrial oxidase inhibitor, did not reduce the 3852 generated ESR signal, whereas DPI $(20 \mu \mathrm{M})$ 
(diphenylene iodonium), a potent and highly selective flavoprotein inhibitor reduced the ESR signal (Figure 26G, E). These results support the hypotheses that NADPH oxidase is responsible for $\mathrm{NSC} 3852$ mediated $\bullet \mathrm{O}_{2}{ }^{-}$generation.

Interestingly, pretreatment with NAC for one hour did not prevent quarter signal formation induced by NSC3852 (Figure 26C). Based on the fact that NADPH oxidase produces $\cdot \mathrm{O}_{2}{ }^{-}$outside the cells, we think that $\cdot \mathrm{O}_{2}{ }^{-}$formed by the cells upon treatment with NSC3852 should enter cells, before it can be reduced by GSH or/and NAC (Figure 29). 


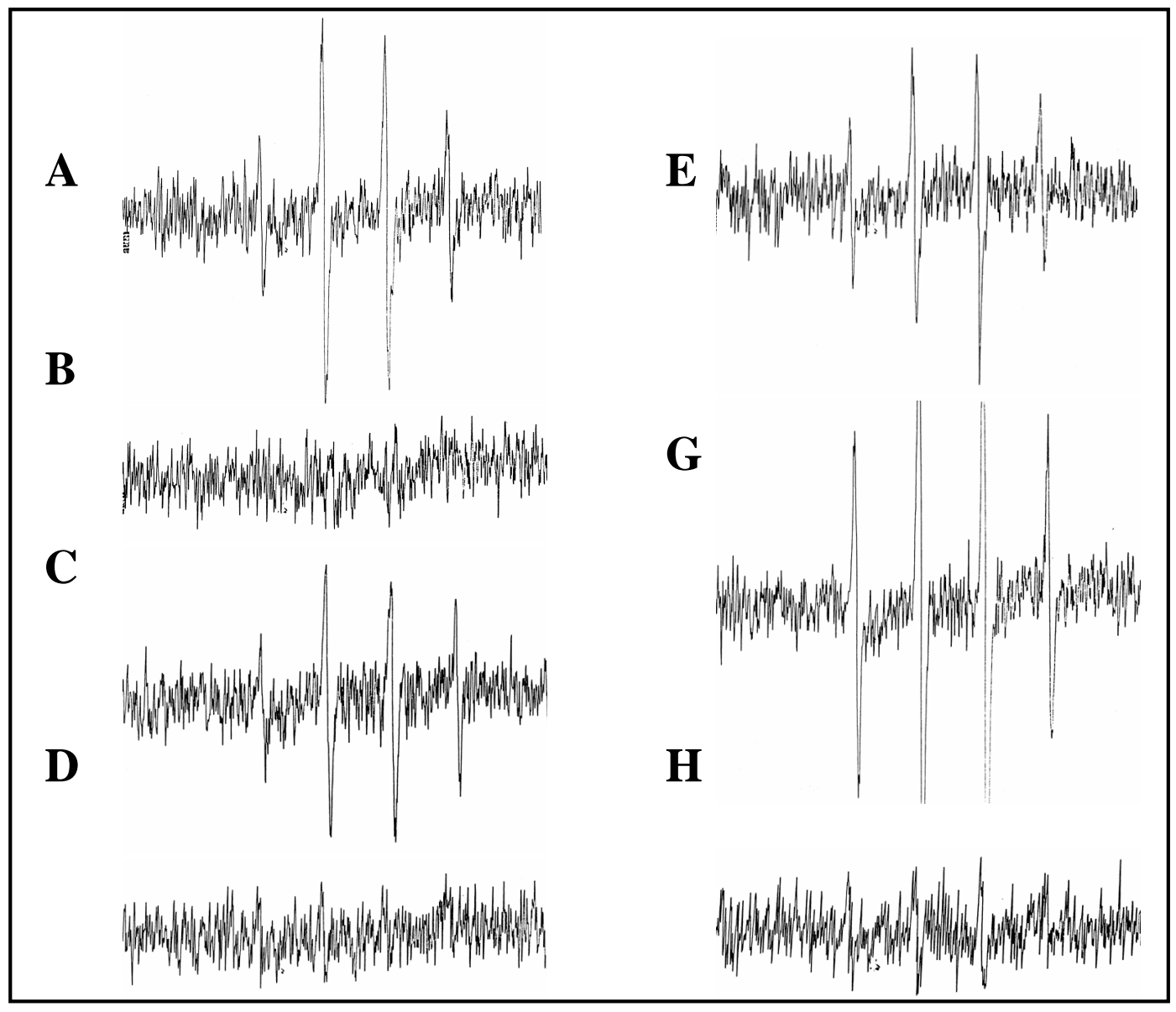

Figure 26. Generation of free radicals in NSC3852 treated MCF-7 cells. ESR spectra of MCF-7 cells (treated as indicated for 5 minutes) were recorded with spin trap DMPO in a $2 \times 10^{6}$ cell suspension in a phosphate buffer solution ( $\left.\mathrm{pH} 7.4\right)$. A) NSC3852 $(10 \mu \mathrm{M})$. B) NSC2039 $(8 \mu \mathrm{M})$. C) Cells pretreated with NAC $(5 \mathrm{mM})$ for one hour and treated with NSC3852 $(10 \mu \mathrm{M})$. D) NSC3852 $(10 \mu \mathrm{M})+\mathrm{DPI}(20 \mu \mathrm{M})$. E) $\mathrm{NSC} 3852(10 \mu \mathrm{M})+$ catalase $(2000 \mathrm{U} / \mathrm{ml})$. G) $\mathrm{NSC} 3852(10 \mu \mathrm{M})+$ rotenone $(50 \mu \mathrm{M})$. H) NSC3852 + SOD $(200 \mathrm{U} / \mathrm{ml})$. The ESR spectrometer settings were: receiver gain, $6.32 \times 10^{4}$; time constant, $4 \mathrm{~ms}$; modulation amplitude, $1.0 \mathrm{G}$; scan time, $41 \mathrm{~s}$; number of scans, 3; and magnetic field, $3480 \pm 100 \mathrm{G}$. 


\subsection{Superoxide visualization by Dihydroethidium}

Intracellular $\cdot \mathrm{O}_{2}^{-}$was visualized using the cell-permeable dye dihydroethidium (Ye J. et al., 1999), which when oxidized by $\cdot_{2}{ }^{-}$emits red fluorescence (intact dihydroethidium exhibits blue fluorescence), as detailed in Materials and Methods.

As shown in Figure 27, twenty four hours exposure of MCF-7 cells to NSC3852 increased accumulation of $\cdot \mathrm{O}_{2}^{-}$in the cells compared to control cells. Increased accumulation of $\cdot \mathrm{O}_{2}^{-}$in the cells in response to $\mathrm{NSC} 3852$ stimulation supports our hypothesis that NSC3852 causes oxidation in MCF-7 cells. 


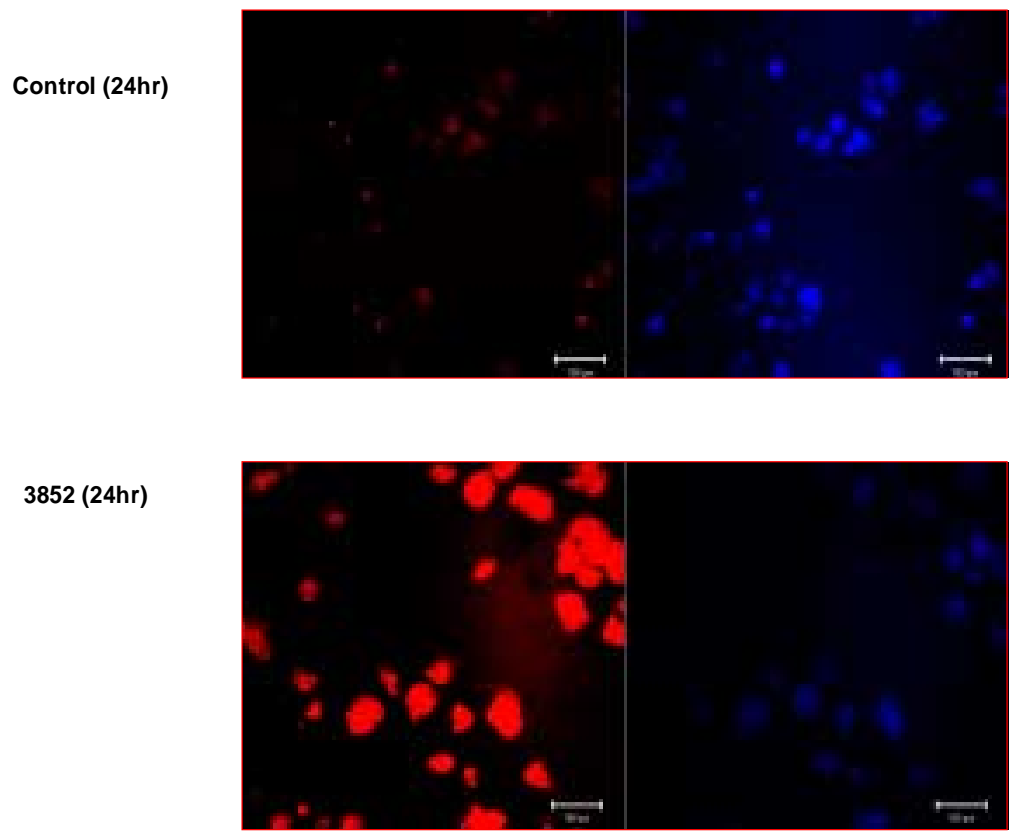

Figure 27. Visualization of superoxide inside the cells. Cells $\left(2.0 \times 10^{5}\right.$ cells $/ 35$ $\mathrm{mm}^{2}$ dish) were plated on sterile glass cover slips, left to attach for 12 hours and stimulated with NSC3852 for 24 hours. Dihydroethidium $(5 \mu \mathrm{M})$ was added into the cell culture for 15 minutes, and the staining was carried out at $37^{\circ} \mathrm{C}$. Cells were washed with PBS, fixed and mounted on slides using anti-fade solution. Cells were visualized using a Zeiss LSM 510 confocal microscope. 


\subsection{GSH/GSSG ratio in MCF-7 cells is altered by NSC3852}

The major redox couple in mammalian cells is glutathione-glutathione disulfide. Changes in GSH/GSSG ratio in the cells indicate changes in the redox status of the cells. NSC3852 stimulated $\cdot \mathrm{O}_{2}^{-}$production in the cells (section 3.7.), thus we predicted that GSH/GSSG ratio in the cells exposed to NSC3852 should reflect this oxidative response activity.

The GSH/GSSG ratio was measured after 15, 60 and 360 minutes of NSC3852 stimulation (Figure 28). Our data indicates that the GSH/ GSSG ratio after the NSC3852 (15, 60 and 360 minute) stimulation, decreased 1.8, 2.5 and 1.25 fold respectively, compared to control cells. This data indicates that superoxide formation induced by NSC3852 shifts a cellular redox status to a more oxidized redox potential. Taken together data presented in Chapter 3 supports our hypothesis that NSC3852 causes mild oxidation of MCF-7 breast cancer cells, which leads to the elevation of redox potential of the cells and this mechanism contributes to the growth arrest, differentiation and apoptosis induced by NSC3852. 


\section{GSH/GSSG ratio}

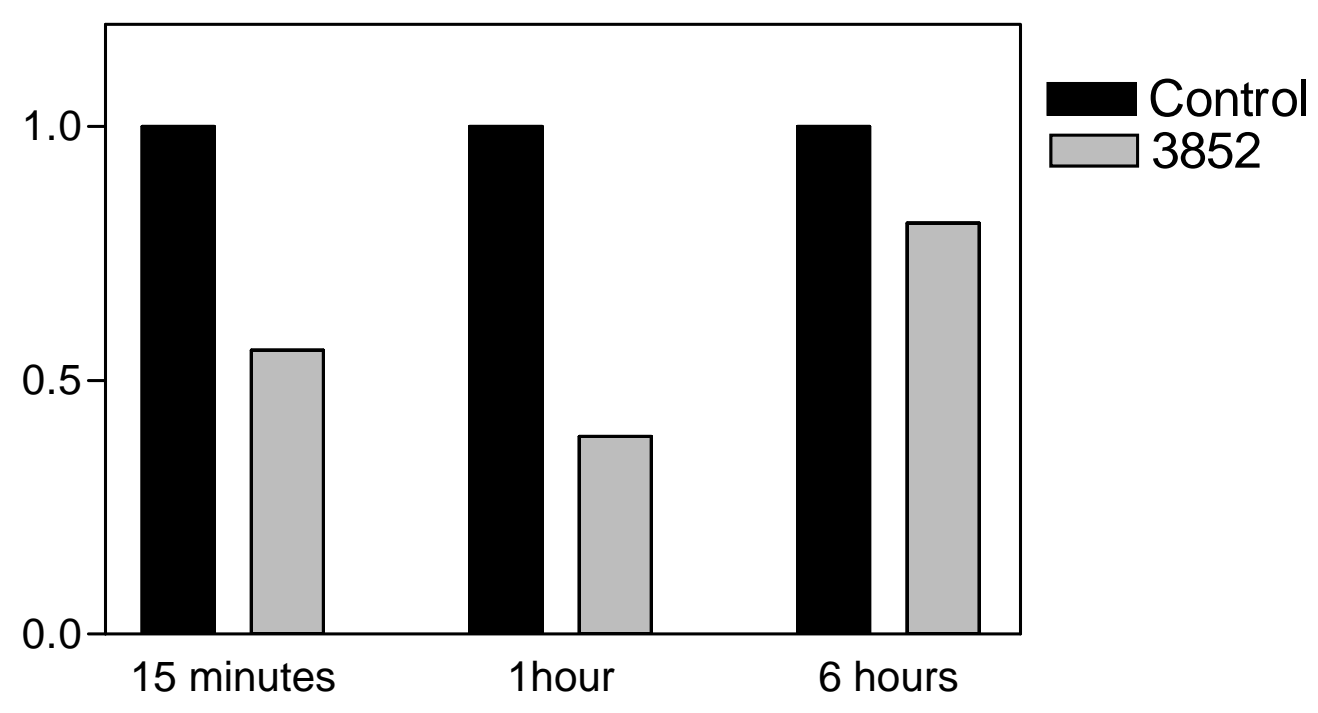

Figure 28. GSH/GSSG ratio in MCF-7 cells treated with NSC3852. MCF-7 cells $(3 \mathrm{x}$ $10^{6}$ cells $/ 60 \mathrm{~mm}^{2}$ dish) were plated, left to attach for 12 hours and NSC3852 $(10 \mu \mathrm{M})$ was added for the time indicated. After the treatment cells were washed, harvested and GSH/GSSG was assayed as described in Materials and Methods. 
Figure 29. Model. Based on the results presented above we propose the following model of NSC3852 mechanism of action.

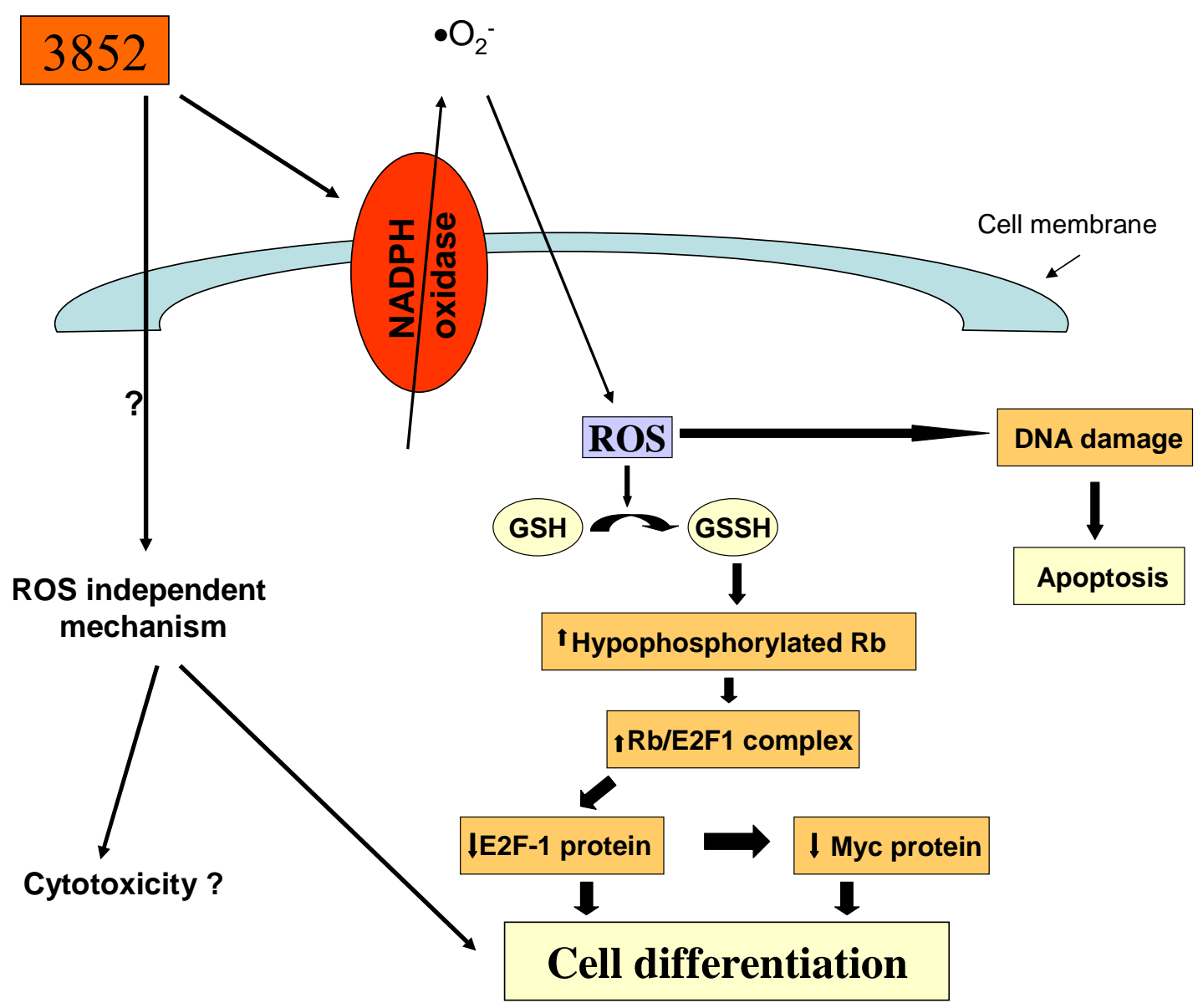




\section{Discussion}

High - throughput screening assays allow rapid screening of large compound libraries to identify the most specific and potent compounds "leads" against known targets. (Hertzberg R., P. et al., 2000). The present study was aimed at identifying a "lead" compound after the screening of quinoline ring-containing compounds obtained from the National Cancer Institute Compound Library as HDAC inhibitors, and further testing of the "lead" compound to identify additional targets.

Cancer cells are poorly differentiated. Thus, the development of therapy that induces the conversion of cancer cells to the original differentiated state, and is better tolerated by patients will be a major advance in the treatment of cancer. Trichostatin A, a direct HDAC inhibitor, causes cell differentiation (Marks P. et al., 2000). Non-HDAC mechanisms of differentiation also exist. The vitamin A derivative, all-trans retinoic acid has been shown to induce differentiation in cancer cells and became the first choice drug in the treatment of acute promyelocytic leukemia (Tobita T. et al., 1997; McBurney M. et al., 1993). Generally, differentiation therapy for solid cancer is ineffective. Therefore, preliminary results from our lab, which showed that quinidine, a quinoline ringcontaining drug, causes cell cycle arrest, cell cycle exit and stimulation of cellular differentiation in MCF-7 breast tumor cells was a promising finding, which suggested that quinidine like compounds might induce differentiation in breast cancer cells (Zhou Q. et al., 2000).

In this study we used Ki-67 and Oil-Red-O assays as indicators of differentiation activity of the screened quinoline ring-containing compounds. Six compounds (NSC 10010, 3852, Chloroquine, 69603, 305819 and 86371) out of 23 compounds screened by 
us were identified as differentiation inducing agents (Figure 7, 8; Table 2). Furthermore, compounds NSC3852 and NSC86371 were identified as in vitro HDAC inhibitory quinolines (Table 2) at concentrations $(10 \mu \mathrm{M}$ and $6 \mu \mathrm{M}$ respectively) that induced differentiation in MCF-7 cells. HDAC is one of the well studied targets for differentiation therapy (Vagushin D.M. et al., 2001). Agents that inhibit HDAC enzymatic activity, such as trichostatin A, superoylanilide hydroxamic acid are able to induce differentiation in transformed cells (Marks P. et al., 2000).Compound NSC2039 is structurally similar to NSC3852, but it lacks nitroso substitution. Interestingly, it had no statistically significant effect on either HDAC activity or Ki67 index.

Six "hits" established by the first round of screening were further screened to select a "lead" compound. We chose the following criterion for further screening: effect of the compounds on MCF-7 cell number. All the differentiation-inducing quinolines caused growth inhibition, measured by viable cell number in growth curves in MCF-7 and MCF-10A cells (Figure 9, 12). Our results indicated that compound NSC305819 was the least toxic of all the differentiation-inducing quinolines in MCF-10A normal human mammary epithelial cells and further investigation is needed to establish whether it has tumor selective activity. NSC3852 and NSC86371 were slightly less growth inhibitory in MCF-10A than in MCF-7 cells. NSC69603 and NSC10010 were more toxic in MCF-10A cells.

We chose the induction of apoptosis as a second criterion for screening. Deregulation of apoptosis plays an important role in cancer. Induction of apoptosis by NSC compounds in time course experiments was tested (Figure 10). After 48 hours of treatment with NSC3852, 86371 and chloroquine apoptosis was detected. By 72 hours 
apoptosis was also detected in cells treated with NSC305819. NSC86371, NSC305819 and NSC3852 induced less apoptosis in MCF-10A cells compared to MCF-7 cells and Chloroquine did not induce apoptosis in MCF-10A cells. These results indicate that induction of apoptosis by NSC3852, 86371, 305819 and Chloroquine contributed to cell death.

The comet assay was used to assay DNA damage in treated cells. After 24 hours of treatment only NSC3852 significantly induced DNA damage in MCF-7 breast cancer cells (Figure 11). DNA damage was not observed in MCF-10A normal epithelial cells after stimulation with differentiation-inducing quinolines. These results suggest some selective toxicity of NSC3852. Time - dependent induction of DNA damage by other differentiation-inducing quinolines will help to determine presence of DNA damage component in induction of apoptosis.

We chose NSC3852 as the "lead" compound because it : a) inhibited cell growth and induced cell differentiation in MCF-7 cells, b) significantly inhibited HDAC activity, c) selectively induced DNA damage in MCF-7 cells with subsequent apoptosis, d) in the rapid in vitro assay of transcellular permeation of drug through artificial lipid membrane (PAMPA) NSC3852 was predicted to be active after oral administration (Martirosyan A.R. et al., 2004), e) meets the Lipinski rule of five: a molecular weight $\leq 500,<5$ hydrogen-bond donors, $<10$ hydrogen-bond acceptors, and an oil-water partition (log P) between -1 and +5 (Lipinski C.A. et al., 1997).

The lead compound NSC3852 exerts multiple effects on MCF-7 breast cancer cells. NSC3852 induced the accumulation of a hypophosphorylated (active) form of $\mathrm{pRb}$ (Figure 14) with expected increase in E2F-1/pRb complex formation in MCF-7 cells 
(Figure 17). E2F-1/pRb repressor complex might recruit other co-repressors (such as HDAC) and bind to the promoter region of E2F-1 target genes inducing cell differentiation (Brehm A. et al., 1998). A second mechanism upon which NSC3852 modulated pRb/E2F-1 pathway was suppression of E2F-1 protein level (Figure 15) and its transcriptional activity (Figure 19), and downregulation of E2F-1 is a necessary precondition for cells to undergo differentiation (Wong C.F. et al., 2003). Furthermore, levels (Figure 18) and transcriptional activity (Figure 19) of Myc transcription factor, which plays a critical role in the control of cell proliferation (Kelly K. et al., 1984), cellular differentiation (Griep A.E. et al., 1988), apoptosis (Zindy F. et al., 1998) and is a downstream effector of E2F also was significantly downregulated by NSC3852. Further investigation is necessary to determine the effect of NSC3852 on the promoter activity of E2F-1 and Myc transcription factors and the routes of their degradation.

Several studies implicate the redox status of the cells in the regulation of $\mathrm{pRb}$ function. Cichillitti L. et al. reported that elevated redox potential causes the accumulation of $\mathrm{pRb}$ in its hypophosphorylated form by inducing protein phosphatase 2A-dependent dephosphoryaltion of $\mathrm{pRb}$, which in turn does not release $\mathrm{E} 2 \mathrm{~F}-1$ protein (Cichillitti L. et al., 2003). Others demonstrated that $\mathrm{N}$-acetylcysteine restores $\mathrm{pRb}$ phosphorylation caused by depletion of intracellular GSH (glutathione) (Yamauchi A. et al., 1997). Glutathione is the primary buffer of intracellular redox potential. To gain further insight into the mechanism of NSC3852 induced $\mathrm{pRb}$ hypophosphorylation in MCF-7 cells we tested the hypothesis that NSC3852 induces slight oxidative stress in MCF-7 cells that can be compensated for by N-acetylcysteine (NAC), a glutathione precursor. Our results demonstrated that NAC blocked accumulation of 
hypophosphorylated pRb. Furthermore, NAC also blocked E2F-1 and Myc protein downregulation induced by NSC3852 (Figure 21). These data suggests that induction of oxidative stress may be involved in the differentiation response to NSC3852.

Reactive oxygen species (ROS), such as superoxide anion, hydrogen peroxide, are an important determinant of cellular redox potential. When mammalian cells are exposed to reactive oxygen species, redox potential of the cells rises. Certain ROS species cause direct DNA damage. NSC3852 was the only differentiation - inducing quinoline that caused DNA damage in MCF-7 cells after 24 hours of treatment, followed by apoptosis after 48 hours of treatment. NAC blocked DNA damage and apoptosis induced by NSC3852 (Figure 23, 24). This led us to the hypothesis that NSC3852 induces ROS formation in MCF-7 cells.

To examine free radical generation mediated by NSC3852 the electron spin resonance (EPR) spin trapping technique was used (Figure 26). Our results indicated that NSC3852 induced $\cdot \mathrm{O}_{2}{ }^{-}$generation in MCF-7 cells via NADPH oxidase system. NADPH oxidase complex is now recognized as a primary source of ROS. NADPH oxidase catalyses one-electron reduction of molecular oxygen, with electron supplied by NADPH. Formed $\cdot \mathrm{O}_{2}{ }^{-}$can be further reduced to hydrogen peroxide and formed ROS pass through the cell membrane inside the cell. Superoxide was visualized in the cells using immunofluorescence technique (Figure 27). Thus, formed superoxide might be responsible for DNA damage as well as the changes in redox status of the cells. A good estimate of redox status of the cell can be calculated from the ratio of glutathione (GSH)/glutathione disulfide (GSSG). Results presented in Figure 28 indicated that superoxide formation induced by NSC3852 shifted a cellular redox status to a more 
oxidized redox potential. The ability of NSC3852 to induce accumulation of hypophosphorylated $\mathrm{pRb}$ and the shift of a cellular redox status to a more oxidized redox potential upon NSC3852 stimulation agrees with the model proposed by Hoffman et al., which presents correlation between redox potential of the cells and $\mathrm{pRb}$ phosphorylation state (Hoffman A. et al., 2001).

Based on the results presented in this study we propose the following model of NSC3852 mechanism of action on MCF-7 breast cancer cells (Figure 29). NSC3852 induces generation of $\bullet \mathrm{O}_{2}{ }^{-}$via NADPH oxidase complex. NADPH oxidase produces $\bullet \mathrm{O}_{2}{ }^{-}$ outside the cells and we think that $\bullet \mathrm{O}_{2}{ }^{-}$formed by the cells upon treatment with NSC3852 entered cells causing oxidative stress. Inside the cells $\bullet \mathrm{O}_{2}{ }^{-}$is partially reduced by GHS. The ratio of GSH/GSSG in the cells is changed leading to the shift in cellular redox status to a more oxidized redox potential. This triggers the $\mathrm{pRb} / \mathrm{E} 2 \mathrm{~F}-1 / \mathrm{Myc}$ pathway modulation and cell differentiation observed upon NSC3852 treatment. Involvement of oxidative stress in induction of differentiation induction is supported by the data demonstrating the inability of NSC2039, quinoline ring compound with no differentiation activity, to induce generation of $\cdot \mathrm{O}_{2}{ }^{-}$in $\mathrm{MCF}-7$ cells (Figure 26). An excess of $\cdot \mathrm{O}_{2}{ }^{-}$(not reduced by GSH) causes direct damage to DNA, which leads to subsequent apoptosis. Determination of oxidative DNA damage (detection of 8-oxoguanine) will help to determine whether the DNA damage induced by NSC3852 is the result of oxidative injury (Ogawa Y. et al., 2003).

Interestingly, neither cell-growth inhibition (Figure 25) nor induction of cell differentiation (Figure 22) observed upon stimulation of MCF-7 cells with NSC3852 was 
fully blocked by NAC. The nature of the NAC-independent effects of NSC3852 in MCF7 cells and its role in growth inhibition remains to be elucidated.

In summary, induction of a more differentiated phenotype by quinoline-ring containing compounds is an important finding, suggesting their potential role in differentiation therapy. Our data showed that atniproliferative activity of NSC3852 differentiation-inducing quinoline ring-containing compound was in part the consequence of NSC3852-induced oxidative stress in MCF-7, which is associated with DNA damage, induction of cell differentiation and apoptosis. It worth mentioning, that newer antimalarial arteminisins are oxidizing agents, and have recently shown promise as breast cancer antiproliferative agents (Efferth T et al., 2002). NSC3852 has a relatively simple chemical structure and is a "lead" compound for further development of anticancer drugs. 


\section{References}

Ayer D. E., Kretzner E. L., Eisenman R. N. Mad: a heterodimeric partner for Max that antagonizes Myc transcriptional activity. Cell, 72: 211-222, 1993.

Bacus, S. S., Kiguchi, K., Chin, D., King, C.R., and Huberman, E. Differentiation of cultured human breast cancer cells (AU-565 and MCF-7) associated with loss of cell surface HER-2/neu antigen. Mol Carcinogen, 3:350-362, 1990.

Bhatia, K., Huppi K., Spangler, G., Siwarski, D., Iyer, R. and Magrath, I. Point mutations in the c-Myc transcription domain are common in Burkitt's lymphoma and mouse plasmacytomas. Nat Genet, 5: 56-61, 1993.

Brehm A., Miska E. A., McCance D. J., Reid J. L., Bannister A. J., Kouzarides T. Retinoblastoma protein recruits histone deacetylase to repress transcription. Nature, 391: 597-601, 1998.

Brehm Alexander and Tony Kouzarides. Retinoblastoma protein meets chromatin. TIBS, 24: 142-145, 1999.

Cicchillitti L., Fasanar P., Biglioli P., Capogrossi M. C., Mertelli F. Oxidative stress induces protein phosphatase $2 \mathrm{~A}$-dependent dephosphorylation of the pocket proteins $\mathrm{pRb}$, p107, and p130. The Journal of Biological Chemistry, 278, 21: 19509-19517, 2003. 
Cobleigh MA, Vogel CL, Tripathy D, Robert NJ, Scholl S, Fehrenbacher L, Wolter JM, Paton V, Shak S, Lieberman G, Slamon DJ. Multinational study of the efficacy and safety of humanized anti-HER2 monoclonal antibody in women who have HER2overexpressing metastatic breast cancer that has progressed after chemotherapy for metastatic disease. J Clin Oncol,17 (9): 2639-2648, 1999.

David M. Vigushin and R. Charles Coombes. Histone deacetylase inhibitors in cancer treatment. Anti-Cancer Drugs, 13, 1-13, 2002.

DePinho R. A., Schreiber-Agus N., Alt F. W. myc family oncogenes in the development of normal and neoplastic cells. Adv. Cancer Res, 57: 1-46, 1991.

De Flora S., Izzotti A., D’Agostini F., Balansky R., M. Mechanisms of N-acetylcysteine in the prevention of DNA damage and cancer, with special reference to smoking-related end-points. Carcinogenesis, 22(7): 999-1013, 2001.

DeGregori J., Leone G., Mironi A., Jakoi L., Nevins J. R. Distinct roles for E2F proteins in cell growth control apoptosis. Proc Natl Acad Sci USA, 94, 7245-7250, 1997.

Duke R. C. and Cohen J. J. IL-2 addition: withdrawal of growth factor activities a suicide program in dependent T cells. Lymphokine Res., 5: 289-299, 1986. 
Dunaief J. L., Strober B. E., Guha S., Khavari P. A., Alin K., Luban J., Begemann M., Crabtee G. R., Goff S. P. The retinoblastoma protein and BRG1 form a complex and cooperate to induce cell cycle arrest. Cell, 79: 119-130, 1994.

Durfee T., Becherer K., Chen P. L., Yeh S. H., Yang Y., Kilburn A. E., Lee W. H., Elledge S. J. The retinoblastoma protein associates with the protein phosphatase type 1 catalytic subunit. Genes Dev, 7(4): 555-69, 1993.

Dyson Nicholas. The regulation of E2F by $\mathrm{pRB}$ - family proteins. Genes and Development, 12,15: 2245-2262, 1998.

Early Breast Cancer Trialists' Collaborative Group. Favorable and unfavorable effects on long-term survival of radiotherapy for early breast cancer: an overview of the randomized trials. Lancet, 355 (9217): 1757-1770, 2000.

Early Breast Cancer Trialists' Collaborative Group. Tamoxifen for early cancer: an overview of the randomized trials. Lancet, 351 (9114): 1451-1467, 1998.

Efferth T., Olbrich A., Bauer R. mRNA expression profiles for the response of human tumor cell lines to the antimalarial drugs artesunate, arteether, and artemether. Biochemical Pharmacology, 64: 617-623, 2002. 
Esposito F., Russo T., Cimino F. Retinoblastoma protein dephosphorylation is an early event of cellular responses to prooxidant conditions. FEBS Lett, 470: 211-215.

Faha B, Ewen M. E., Tsai L. H., Livingston D. M., Harlow E. Interaction between human cyclin A and adenovirus E1A-associated p107 protein. Science, 255: 87-90, 1992.

Fisher B., Anderson S., Bryant, J., Margolese R.G., Deutsch M., Fisher E.R., Jeong J-H, Wolmark N. Twenty-year follow-up of a randomized trial comparing total mastectomy, lumpectomy, and lumpectomy plus irradiation for the treatment of invasive breast cancer. N Engl J Med, 347(16): 1233-1241, 2002.

Finkel T, Holbrook NJ. Oxidants, oxidative stress and the biology of aging. Nature, 408(6809):239-47, 2000.

Gabig T. G., Crean C. D., Mantel P. L., Rosli R. Function of wild-type of mutant Rac2 and Rap1a GTPase in differentiated HL-60 cell NADPH oxidase activation. Blood, 85: 8004-811, 1995.

Galaktionov K., Chen X., Beach D. Cdc25 cell-cycle phosphatase as a target of c-myc. Nature, 382:511-517, 1996.

Gerard I. Evan and Karen H. Vousden. Proliferation, cell cycle and apoptosis in cancer. Nature 411, 342-348, 2001. 
Gerdes J., Lemke H., Baisch H., Wacker H-H, Shwab U., Stein H. Cell cycle analysis of a cell proliferation-associated human nuclear antigen defined by the monoclonal antibody Ki-67. J. Immunol. 133, 1710, 1984.

Gillett C. E., Barnes D. M. Cell cycle. J Clin: Mol Pathol, 51: 310-316, 1998.

Griep A. E. and Wesphal H. Antisense Myc sequences induce differentiation of F9 cells. Proc Natl Accd Sci USA. 85: 6806-6810, 1988.

Grunstein M. Histone acetylation in chromatin structure and transcription. Nature, 25: 389(6649):349-52, 1997.

Guetens G., De Boeck G., Highley M., Van Oosterom A., T., de Bruijn E., A. Oxidative DNA damage: biological significance and methods of analysis. Crit. Rev. Clin. Lab. Sci., 39(4-5): $331-457,2002$

Hallstrom T.,C. and Nevins J., R. Specificity in the activation and control of transcription factor E2F - dependent apoptosis. PNAS, 100, 19: 10848-10853, 2003.

Hanahan D., Weinberg R., A. The Hallmarks of cancer. Cell, 100: 57-70, 2000. 
Hancock J. T., Desikan R., and Neill S. J. Role of reactive oxygen species in cell signaling pathways. Biochemical Society Transaction, 29(2): 345-350, 2001.

Hateboer G., Kerkhoven R. M., Shvarts A., Bernards R., Beijersbergen R. L. Degradation of E2F by ubiquitin-proteasome pathway: Regulation by retinoblastomafamily proteins and adenovirus transforming proteins. Genes \& Dev, 10: 2960-2970, 1996.

Hermeking H., Rago C., Schuhmacher M., Li Q., Barrett J. F., Obaya A. J., O'Connell B. C., Mateyak M. K., Tam W., Kohlhuber F, Dang C. V., Sedivy J. M., Eick D., Vogelstein B., Kinzler K. W. Identification of CDK4 as a target of c-MYC. Proc Natl Acad Sci USA, 97(5):2229-34, 2000.

Helin K., Wu C. L., Fattaey A. R., Lees J. A., Dynlacht B. D., Ngwu C., Harlow E. Heterodimerization of the transcription factors E2F-1 and DP-1 leads to cooperative trans-activation. Genes Dev. 7:1850-1861, 1993.

Hertzberg R., P. and Pope A., J. High - throughput screening: new technology for the $21^{\text {st }}$ century. Curr Opin Chem Biol, 4: 445-451, 2000.

Hiebert, S., W., Lipp, M., and Nevins, J., R. E1A - dependent trans - activation of human MYC prooter is mediated by the E2F factor. Proc. Natl. Acad. Sci. USA, 86: 3594-3598, 1989. 
Hoffman A., Lee M. Spetner and M. Burke. Cessation of cell proliferation by adjustment of cell redox potential. J.Theor. Biol., 211: 403-407, 2001

Hortobagyi G., N. Treatment of breast cancer. N Engl J Med, 339 (14): 974-984, 1998.

Hulka B.,S., Moorman P., G., Breast cancer: hormones and other risk factors. Maturitas, 38(1):103-113, 2003.

Jansen-Durr P., Meichle A.,Steiner P., Pagano M., Finke K., Botz J., Wessbecher J., Draetta G., Eilers M. Differential modulation of cyclin gene expression by MYC.Proc Nat'l Acad Sci USA, 90: 3685-3689, 1993.

Janzen E. G., Balckburn B. J. Detection and identification of short-lived free radicals by an electron spin resonance trapping technique. J. Am. Chem. Soc. 90: 5909-5910, 1968.

Jemal A., Murray T., Samuels A., Ghafoor A., Ward E., Thun MJ. Cancer statistics. $C A$ Cancer J Clin., 53(1): 5-26, 2003

Jing, Y., Zhang, J., Waxman, S., and Mira-y-Lopez, R. Upregulation of cytokeratins 8 and 18 in human breast cancer T47D cells is retinoid-specific and retinoic acid receptordependent. Differentiation, 60:109-117, 1996. 
Johnson D. G., Ohtani K., Nevins J. R. Augmentation control of E2F-1 expression in response to positive and negative regulation of cell cycle progression. Genes Dev, 8: 1514-1525, 1994.

Johnston P., A. Cellular platform for HTS: three case studies. Drug Discov Today, 7: 353-363, 2002.

Jones D. P. Redox potential of GSH/GSSG couple: assay and biological significance. Met Enzymol, 348: 93-113, 2002.

Katja C. Zimmermann and Douglas R. Green. How cells die: Apoptosis pathways. J. Allergy Clin. Immunol, 108, 4: 99-103, 2001.

Kelly K., Cochran B. H., Stiles C. D., Leder P. Cell-specific regulation of the c-myc gene by lymphocyte mitogens and platelet-derived growth factor. Cell, 35: 603-610, 1983.

Knudsen E. S., Wang J. Y. Differential regulation of retinoblastoma function by specific cdk phosphorylation sites. J boil Chem, 271: 8313-8320, 1996.

Knudsen E. S., Wang J. Y. Dual mechanism for the inhibition of E2F binding to RB by cyclin-dependent kinase mediated RB phosphorylation. Mol Cell Biol, 17: 5771-5783, 1997. 
Koren R., Hadari-Naor I., Zuck E., Rotem C., Liberman U. A., Ravid A. Vitamin D is a prooxidant in breast cancer cells. Cancer Res, 61: 1439-1444, 2001.

Krek W., Ewen M. E., Shirodkar S., Arny Z., Kaelin W. G., Livingston D. M. Negative regulation of the growth-promoting transcription factor E2F-1 by a stably bound cyclin A-dependent protein kinase. Cell, 78: 161-172, 1994.

Lee I.O., Russo A.A., Pavletich N.P. Structure of the retinoblastoma tumorsuppressor pocket domain bound to a peptide from HPV E7. Nature 391:859-865, 1998.

Leone G., DeGregori J., Sears R., Jakoi L., and Nevins J. R. Myc and Ras collaborate in inducing accumulation of active cyclin E/CDK2 and E2F. Nature (Lond.), 387; 422-426, 1997.

Leone G., Sears R., Huang E., Remple R., Nuckolls F., Park C. H., Giangrande P., Wu L., Saavedra H., Field S. J., Thompson M. A., Yang H., Fujiwara Y., Greenberg M. E., Orkin S., Smith C., Nevins J. R. Myc requires distinct E2F activity to induce S phase and apoptosis. Mol Cell, 8: 105-113, 2001.

Li Y., Graham C., Lacy S., Duncan A. M., Whyte P. The adenovirus E1-associated 130$\mathrm{kD}$ protein is encoded by a member of the retinoblastoma gene family member and physically interacts with cyclins A and E. Gene Dev, 7: 2366-2377, 1993. 
Lipinski C. A. , Lombardo F., Dominy B. W., Feeney P. J. Experimental and computational approaches to estimate solubility and permeability in drug discovery and development settings. Adv Drug Res, 23: 3-25, 1997.

Lohka, M. J., M. K. Hayes, J. L. Maller. Purification of maturation-promoting factor, an intracellular regulator of early mitotic events. Proc. Natl. Acad. Sci. U.S.A., 85: 30093013, 1988.

Magnaghi J.L., Groisman R., Naguibneva I., Robin P., Lorain S., Le V.J., Troalen F., Trouche D., Harel B.A. Retinoblastoma protein represses transcription by recruiting a histone deacetylase. Nature, 391: 601-605, 1998.

Maione R., Amati P. Independence between muscle differentiation and cell cycle control. Biochem. Biophys. Acta, 1332 (1): M19-30, 1997.

Marcu K. B., Bossone S. A., Patel A. J. myc function and regulation. Annu Rev Biochem, 61: 809-860, 1992.

Marks P., Richon V., Rifkind R. Histone deacetylase inhibitors: inducers of differentiation or apoptosis of transformed cells. J Natl. Cancer Inst. 92(15):1210-1216, 2000. 
Martirosyan A. R., Rahim-Bata R., Freeman A. B., Clarke C. D., Strobl J. S. Identification of differentiation - inducing quinolines as experimental breast cancer agents in the MCF-7 human breast cancer cell model. Biochemical Pharmacology, 2004.(in press)

Mates J., M, Sanchez-Jimenez F. Antioxidant enzymes and their implications in pathophysiologic processes. Front Biosci, 15(4): D339-45, 1999.

Mayol X., Grana X., Baldi A., Sang N., Hu Q., Giordano A. Cloning of a new member of the retinoblastoma gene family ( $\mathrm{pRb} 2)$ which binds to the E1A transforming domain. Oncogene, 8: 2561-2566, 1993.

Mehlhase J., Gieche J., Ullrich O., Sitte N., Grune T. LPS-induced protein oxidation and proteolysis in BV-2 microglial cells. IUBMB Lif:50 (4-5) :331-5, 2000.

McBurney M.W., Costa S., Pratt C. Retinoids and cancer: a basis for differentiation therapy. Cancer Investigation, 11: 590-598, 1993.

Momand J., D. Jung, S. Wilczynski, J. Niland. The MDM2 gene amplification database. Nucleic Acids Res., 26 (15): 3453-3459, 1998.

Morgenbesser S. M., Williams B. O., Jacks T., And Depinho R. A. p53-dependent apoptosis produced by Rb-deficiency in the developing mouse lens. Nature, 371: 72-74, 1994. 
Moroni M. C., Hickman E. S., Dechi E. L., Caprara G., Colli E., Cecconi F., Muller H., Helin K. Apaf-1 is a transcriptional target for E2f and p53. Nat. Cell Biol, 3: 552-558, 2001.

Morre D. J., A multifunctional ectoprotein of the eukaryotic cell surface. In: Plasma Membrane Redox Systems and Their Role in Biological Stress and Disease. 121-156, 1998.

Nevins J. R. Toward an understanding of the functional complexity of the E2F and retinoblastoma families. Cell Growth Differ, 9: 585-593, 1998.

Ogawa Y., Kobayashi T., Nishioka A., Kariya S., Hamasato S., Seguchi H., Yoshida S. Radiation-induced reactive oxygen species formation prior to oxidative DNA damage in human peripheral T cells. International journal of molecular medicine, 11: 149-152, 2003.

Pomerantz J., Schreiber-Agus N, Liegeois J., Silverman A., Alland L., Chin L., Potes J., Chen K., Orlow I., Lee H. W., Cordon-Cardo C., DePinho RA. The Ink4a tumor suppressor gene product, p19Arf, interacts with MDM2 and neutralizes MDM2's inhibition of p53. Cell, 92: 713-723, 1998.

Rosen G. M., Finkelstein E. Use of spin - traps in biological systems. Adv. Free Radic. Biol. Med., 1: 345-375, 1985. 
Qian Y., Luckey C., Horton L., Esser M., Templeton D. J. Biological function of the retinoblastoma protein requires distinct domains for hypophosphorylation and transcription factor binding. Mol Cell Biol, 12: 5363-5372, 1992.

Sardet C., Vidal M., Cobrinik D., Geng Y., Onufryk C., Chen A. and Weinberg R. A. E2F-4 and E2F-5, two members of the E2F family, are expressed in the early phases of the cell cycle. Proc Natl acad Sci USA, 92: 2403-2407, 1995.

Seralini G., Moslemi S. Aromatase inhibitors: past, present and future. Mol Cell Endocrinol, 178 (1-2): 117-131, 2001.

Sherr C. J. Cancer cell cycle. Science, 274: 1672-1677, 1996

Shichiri M., Hanson k. D., Sedivy J.M. Effects of c-myc expression on proliferation, quiescence, and the G0 to G1 transition in nontransformed cells. Cell Growth Diff, 4: 93104, 1993.

Slansky J. E. and Farnham P. J. Introduction to the E2F family: protein structure and gene regulation. Curr Topics in Microbiol Immunol, 208: 1-30, 1996.

Spencer C. A. and Groudine M. Control of c-myc regulation in normal and neoplastic cells. Adv Cancer Res, 56: 1-48, 1991. 
Tallman M. S., Janet W. Andersen, Charles A. Schiffer, Frederick R. Appelbaum, James H. Feusner, Angela Ogden, Lois Shepherd, Cheryl Willman, Clara D. Bloomfield, Jacob M. Rowe, and Peter H. Wiernik. All-trans-retinoic acid in acute promyelocytic leukemia. New Engl. J. Med. 337: 1021-1028, 1997.

Tardif M., Rabiet M. J., Christophe T., Milcent M. D., Isolationand characterization of a variant HL-60 cell line defective in the activation of the NADPH oxidase by phorbol myristate acetate. J. Immuno, 161: 6885-6895, 1998.

Tice R. R., E. Agurell, D. Anderson, B. Burlinson, A. Hartmann, H. Kabayashi, Y. Miyamae, E. Rojas, J.-C. Ryu, and Y. F. Sasaki. Single cell gel/Comet assay: guidelines for in vitro and in vivo genetic toxicology testing. Environmental and Molecular Mutagenesis, 35: 206-221, 2000.

Tobita T., Takeshita A., Kitamura K., Ohnishi K., Yanagi M., Hiraoka A., Karasuo T., Takeuchi M.,. Miyawaki S., Ueda R., Naoe T., Ohno R. Treatment with a new synthetic retinoid, Am80, of acute promyelocytic leukemia relapsed from complete remission induced by all-trans retinoic acid. Blood, 90: 967-973, 1997.

Tonini T., Christina Hillson and Pier Paolo Claudio. Interview with the retinoblastoma family members: do they help each other? Journal of cellular Physiology, 192: 138-150, 2002. 
Trimarchi J. M., Fairchild B., Verona R., Moberg K., Andon N. and Lees J. A. E2F-6, a member of the E2F family that can behave as a transcription repressor. Proc. Natl Acad. Sci. USA, 95: 2850-2855, 1998.

Trimarchi J.,M. and Lees J.,A. Sibling rivalry in the E2F family. Molecular Cell Biology, 3: 11-20, 2002.

Vigushin D. M., Simak Ali, Paul E. Pace, Nina Mirisaidi, Kazuhiro Ito , Ian Adcock, and R. Charles Coombes. Trichostatin A is a histone deacetylase inhibitor with potent antitumor activity against breast cancer in vivo. Clinical Cancer Research, 7: 971-976, 2001.

Voorhoeve P. M., Watson R. J., Farlie P. G., Bernards R. and Lam E. W. Rapid dephosphorylation of p107 following UV irradiation. Oncogene, 18: 679-688).

Wang S., Melkoumian Z., Woodfork K., Cather C., Davidson A., Wonderlin W., and Strobl J. Evidence for an early $\mathrm{G}_{1}$ ionic events necessary for cell cycle progression and survival in MCF-7 human breast carcinoma cell line. J Cell Physiol, 176:456-464, 1998.

Wang S., Rosengren L. E., Hamberger A., and Haglid K. G. An acquired sensitivity to $\mathrm{H}_{2} \mathrm{O}_{2}$ - induced apoptosis during neuronal differentiation of NT2/D1 cell. Neuroreport 9, 3207-3211, 1998. 
Wong C., F., Liam M. Barnes, Alison L. Dahler, Smith 1., Magdalena M. Serewko-Auret M.M., Popa C., Abdul-Jabbar I. and Saunders N.A. E2F modulates keratinocyte squamous differentiation. The Journal of Biological Chemistry, 278, 31: 28516-28522, 2003.

Wu X., Levine A. J. p53 and E2F-1 cooperate to mediate apoptosis. Proc Natl Acad Sci USA, 91: 3602-3606, 1994.

Xiao B., Spancer J., Clements A., Ali-Khan N., Mittnach S., Broceno C., Burghammer M., Perrakis A., Marmorstein R., and Gamblin S. J. Crystal structure of the retinoblastoma tumor suppressor protein bound to $\mathrm{E} 2 \mathrm{~F}$ and the molecular basis of its regulation. PNAS, 100 (5): 2363-2368, 2003.

Xiao-Feng Le, Amada McWatters, Jon Wiener, Ji-Yuan Wu, Gordon B.Mills, and Robert C. Bast, Jr. Anti-HER2 antibody and heragulin suppress growth of HER2-overexpressing human breast cancer cells through different mechanism. Clinical Cancer Reaserch, 6: 260-270, 2000.

Yamauchi A. and Bloom E. T. control of cell cycle progression in human natural killer cells through redox regulation of expression and phosphorylation of retinoblastoma gene product protein. Blood, 89: 4092-4099, 1997. 
Ye J., Leonard S., Sun S., Butterworth Y., Antonini J., Dring M., Rojanasakul Y., Vallyathan V., Castranova V., Shi X. Role of reactive spicies and p53 in Chromium (VI)induced apoptosis. J. Biol. Chem. 274: 34974-34980, 1999.

Yee A. S., Heather H. Shih, and Sergei G. Tevosian. New perspectives on retinoblastoma family functions in differentiation. Frontiers in Bioscience, 3: 532-547, 1998.

Zarkowska T., Mittnatcht S., Differential phosphorylation of the retinoblastoma protein by $\mathrm{G}_{1} / \mathrm{S}$ cyclin-dependent kinases. J Biol Chem, 272: 12738-12746, 1997.

Zheng L. and Lee W. H. The retinoblastoma gene: a prototypic and multifunctional tumor suppressor. Exp. Cell Res. 264: 2-18, 2001.

Zhou Q., Melkoumian Z.K., Lucktong A., Moniwa M., Davie J.R., Strobl J.S. Rapid induction of histone hyperacetylation and cellular differentiation in human breast tumor cell lines following degradation of histone deacetylase-1. J Biol Chem, 275(45):35256$35263,2000$.

Zindy F., Eischen C. M., Randle D. H., Kamijo T., Cleveland J. L., Sherr C. J., Roussel M. F. Myc signaling via the ARF tumor suppressor regulates p53-dependent apoptosis and immortalization. Genes \& Dev., 12: 2424-2433, 1998. 